\title{
ESTRUTURA GENÉTICA DE POPULAÇÕES DE Encholirium (BROMELIACEAE) E IMPLICAÇÕES PARA SUA CONSERVAÇÃO
}

MARCELO MATTOS CAVALLARI

Dissertação apresentada à Escola Superior de Agricultura "Luiz de Queiroz", Universidade de São Paulo, para obtenção do título de Mestre em Agronomia, Área de Concentração: Genética e Melhoramento de Plantas.

P I R A C I C A B A

Estado de São Paulo - Brasil

Agosto - 2004 


\section{ESTRUTURA GENÉTICA DE POPULAÇÕES DE Encholirium (BROMELIACEAE) E IMPLICAÇÕES PARA SUA CONSERVAÇÃO}

\section{MARCELO MATTOS CAVALLARI}

Engenheiro Agrônomo

Orientador: Profa. Dra. ELIZABETH ANN VEASEY

Dissertação apresentada à Escola Superior de Agricultura "Luiz de Queiroz", Universidade de São Paulo, para obtenção do título de Mestre em Agronomia, Área de Concentração: Genética e Melhoramento de Plantas.

P I R A C I C A B A

Estado de São Paulo - Brasil

Agosto - 2004 


\title{
Dados Internacionais de Catalogação na Publicação (CIP) DIVISÃO DE BIBLIOTECA E DOCUMENTAÇÃO - ESALQ/USP
}

\author{
Cavallari, Marcelo Mattos \\ Estrutura genética de populações de Encholirium (Bromeliaceae) e implicações para \\ sua conservação/ Marcelo Mattos Cavallari.-Piracicaba, 2004. \\ 92 p. :il. \\ Dissertação (mestrado) - - Escola Superior de Agricultura Luiz de Queiroz, 2004. \\ Bibliografia. \\ 1 Bromélia 2.Bromeliaceae 3. Conservação biológica 4. Diversidade genética 5. \\ Genética de populações 6. Marcador molecular 7. Plantas em extinção I. Título
}

CDD 635.93422

\section{"Permitida a cópia total ou parcial deste documento, desde que citada a fonte- 0 autor"}




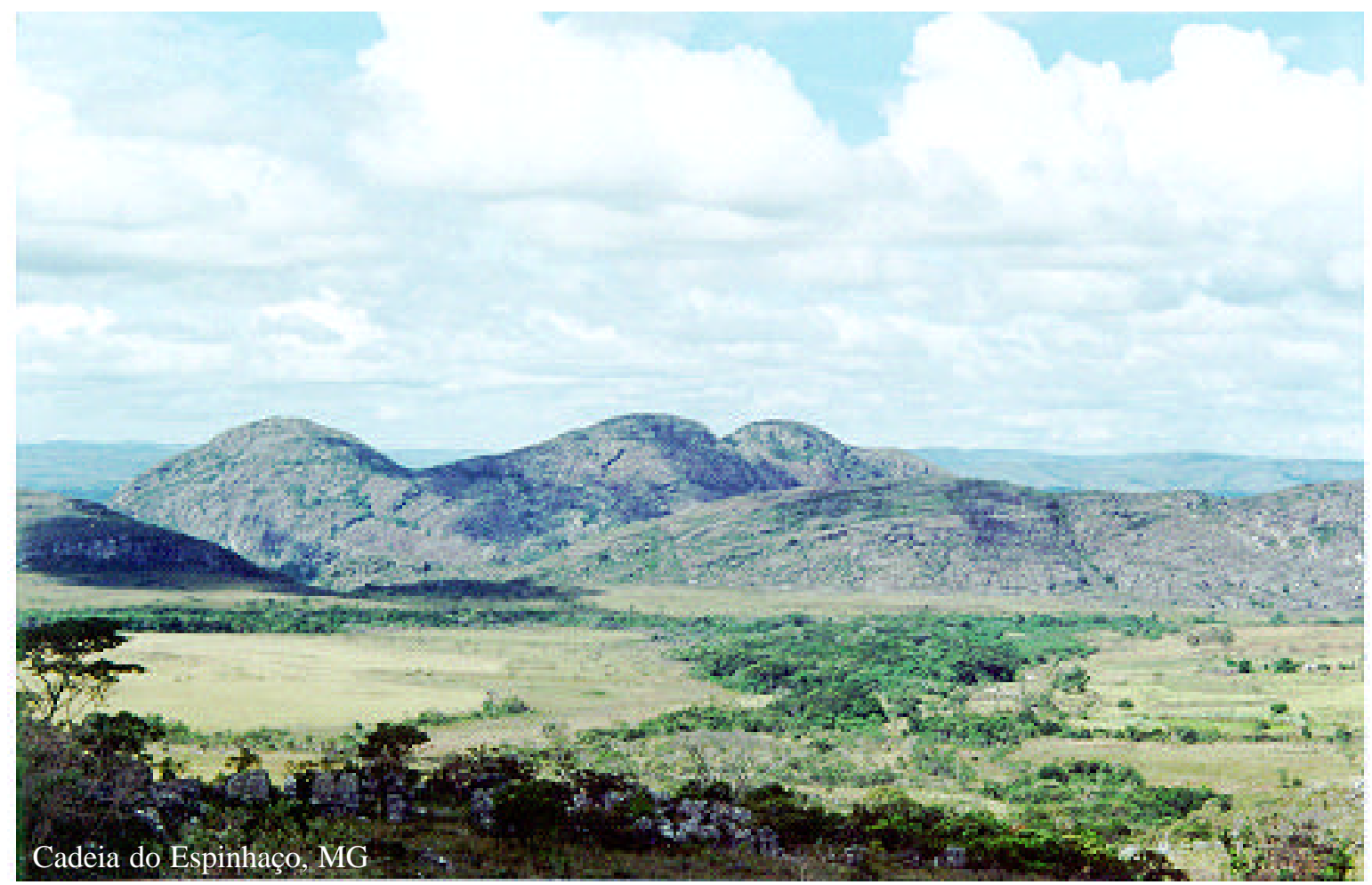

"Nada em biologia faz sentido, exceto à luz da evolução"

Theodosius Dobzhansky 
Ofereço este trabalho aos meus pais, em retribuição ao seu apoio incondicional. Com eles aprendi a importância de buscar a realização naquilo que traz satisfação.

Dedico este trabalho ao meu avô Edu, que sempre incentivou os meus estudos e à minha querida avó Zoca, por estar sempre presente. 


\section{AGRADECIMENTOS}

Definitivamente, uma tese não é um trabalho que se pode fazer sozinho. Durante o tempo em que estive nesta empreitada, muitas foram as pessoas que me ajudaram de alguma forma.

Gostaria de agradecer aos meus quatro "orientadores",

Prof. Dr. Giancarlo Conde Xavier Oliveira, pelo acompanhamento deste trabalho, desde seu início, desde a idealização e delineamento, até sua finalização, participando efetivamente de todas as etapas e decisões, dividindo as pequenas vitórias e enfrentando os problemas. Obrigado pela confiança e amizade! Obrigado pelo suporte científico! Obrigado por me ensinar que o mais importante é procurar perguntas, e não respostas! Obrigado por ter sido, durante todo o tempo, meu orientador.

Profa. Dra. Elizabeth Ann Veasey, pela orientação, pela atenção e amizade. Obrigado pelo apoio e pela estrutura oferecida, possibilitando a realização deste trabalho.

Dra. Rafaela C. Forzza, pela orientação extra-oficial. Obrigado pela sua ajuda inestimável na realização deste trabalho. Sem você, teria sido impossível. Obrigado por ter me apresentado os Encholirium, e ter mudado o rumo do meu mestrado! Obrigado por ter me apresentado os Campos Rupestres, isso valeu mesmo! Obrigado pelas conversas e pelo incentivo à pesquisa.

Prof. Dr. Isaias Olivio Geraldi, por ter assumido a minha orientação por tanto tempo. Muito obrigado pelo apoio e oportunidade. 
Gostaria de agradecer também:

À Dra. Maria Imaculada Zucchi, pela ajuda inestimável na análise estatística dos dados. Obrigado por tudo o que me ensinou (não foi pouca coisa). Obrigado pela incansável ajuda na leitura dos géis (o que não é tarefa para qualquer um!) e pela inabalável boa vontade. Obrigado pela revisão criteriosa deste trabalho. Obrigado também pela amizade.

Ao Prof. Dr. Roland Vencovsky, pelas críticas e sugestões tão pertinentes. Obrigado pela enorme atenção dispensada. Obrigado pelo exemplo de amor à ciência e à docência.

Ao Prof. Dr.Vicente José Maria Savino e Prof. Dr. Antonio Coelho, pelo empréstimo de materiais indispensáveis à realização da pesquisa, e por terem me recebido temporariamente em seu laboratório. Não é sempre que encontramos pessoas dispostas a compartilhar. Obrigado também aos colegas Millor e Pitu por me receberem no Laboratório de Genética Molecular de Aves e terem me dado todo o suporte necessário para a realização daquela etapa.

Aos colegas Eduardo, Marines, Maria Inês, e Eva, do Laboratório de Ecologia Evolutiva e Genética Aplicada, onde desenvolvi este trabalho, pela amizade, convívio e ajuda. Obrigado ao amigo Ronaldo José Rabello, pela atenção e convívio, sem contar o auxílio na maceração de mais de 400 amostras de Encholirium.

À Profa. Dra. Aline Pizzirani Kleiner, por ter gentilmente cedido amostras de primers para os testes. Aos colegas do Laboratório de Microorganismos, especialmente à Mayra, por ter aliquotado pacientemente todas as amostras.

Aos colegas do Laboratório de Biologia Celular, aos quais recorri muitas vezes para tirar dúvidas, e que sempre deram demonstrações de boa vontade. Obrigado ao Carlinhos, Juliano, Éder e especialmente ao Francisco (XV), pela atenção.

À Sociedade Brasileira de Bromélias, que me ajudou em duas etapas. Primeiro, através do "Programa de Incentivo à Pesquisa", graças ao qual eu decidi realizar este mestrado. Depois, pelo enorme apoio à realização deste trabalho. Obrigado em especial ao Orlando Graeff e Ivo Penna, pela amizade, incentivo e oportunidades. 
À amiga Olga Satie Suzuki, por ter me ensinado a trabalhar com marcadores moleculares, com precisão e rigor necessários, e por ter me incentivado a realizar o mestrado. Obrigado, Olga (você também faz parte desta história!).

Gostaria de agradecer à minha companheira Carla, por me mostrar do quanto sou capaz, me apoiando e me dando força nas horas mais difíceis, e sorrindo junto comigo ao ver pronto este trabalho.

Agradeço ao Fundo Mundial para a Natureza (WWF), pelo apoio financeiro à realização desta pesquisa, cedido através do Programa "Natureza e Sociedade" e ao CNPq, pela concessão da bolsa de mestrado. 


\section{SUMÁRIO}

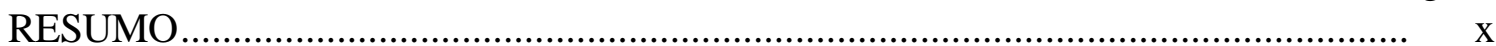

SUMMARY

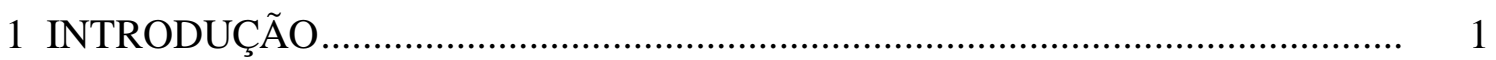

2 REVISÃO DE LITERATURA..................................................................... 4

2.1 O gênero Encholirium............................................................................... 4

2.1.1 Encholirium biflorum (Mez) Forzza............................................................ 7

2.1.2 Encholirium pedicellatum (Mez) Rauh......................................................... 9

2.1.3 Encholirium subsecundum (Baker) Mez................................................... 10

2.2 Encholirium e extinção............................................................................... 12

2.3 A importância da manutenção da variabilidade genética................................... 15

2.4 Estrutura genética de populações................................................................ 17

2.5 Estrutura genética de populações de plantas clonais......................................... 18

2.6 Implicações do conhecimento da estrutura genética de populações na conservação de espécies............................................................................... 20

2.7 Amostragem para estudo da estrutura genética de populações e para a formação de coleções ex situ........................................................................... 24

2.8 Técnicas moleculares para o estudo da estrutura genética de populações:

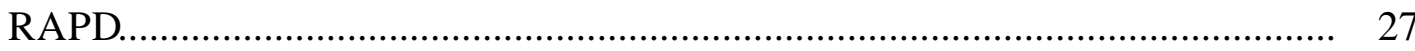

2.9 Análise de variância molecular (AMOVA)................................................. 32

3 MATERIAIS E MÉTODOS.......................................................................... 35

3.1 Observações de campo......................................................................... 35 
3.2 Amostragem do material............................................................................... 36

3.2.1 Critérios gerais de amostragem.............................................................. 36

3.2.2 Amostragem de E. biflorum ..................................................................... 37

3.2.3 Amostragem de E. pedicellatum.............................................................. 38

3.2.4 Amostragem de E. subsecundum............................................................ 39

3.2.5 Armazenamento e transporte das amostras..................................................... 44

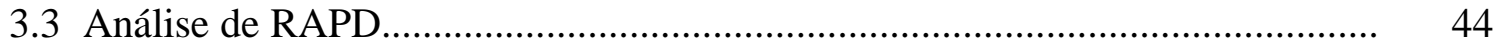

3.3.1 Extração de DNA.................................................................................. 44

3.3.2 Quantificação e padronização das amostras de DNA........................................ 46

3.3.3 Teste e seleção de primers de RAPD............................................................... 47

3.3.4 Otimização da reação de PCR....................................................................... 47

3.3.5 Reações de PCR.................................................................................... 48

3.4 Análise estatística dos dados.......................................................................... 49

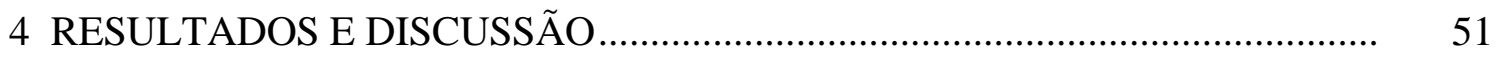

4.1 Observações de campo................................................................................. 51

4.1.1 Encholirium biflorum........................................................................ 51

4.1.2 Encholirium pedicellatum...................................................................... 52

4.1.3 Encholirium. subsecundum..................................................................... 53

4.2 Teste e seleção de primers............................................................................... 54

4.3 Análise estatística dos dados........................................................................... 56

4.4 Implicações para conservação........................................................................ 75

4.4.1 Conservação ex situ................................................................................... 75

4.4.2 Conservação in situ....................................................................................

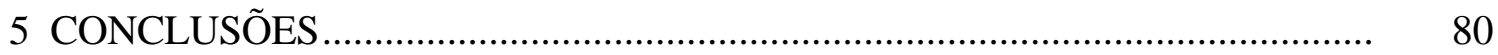

REFERÊNCIAS BIBLIOGRÁFICAS ………………………………………..... 82 


\title{
ESTRUTURA GENÉTICA DE POPULAÇÕES DE Encholirium (BROMELIACEAE) E IMPLICAÇÕES PARA SUA CONSERVAÇÃO
}

\author{
Autor: MARCELO MATTOS CAVALLARI \\ Orientador: Profa. Dra. ELIZABETH ANN VEASEY
}

\section{RESUMO}

Encholirium é um gênero de Bromeliaceae de distribuição restrita ao território brasileiro, ocorrendo exclusivamente em afloramentos rochosos nos domínios do Cerrado, Caatinga e Floresta Atlântica, e com centro de diversidade na Cadeia do Espinhaço de Minas Gerais. Possui 23 espécies, das quais 12 não estão protegidas por nenhuma Unidade de Conservação. O objetivo deste trabalho foi gerar informações úteis para a conservação de três espécies deste gênero, endêmicas da porção mineira da Cadeia do Espinhaço, através da análise da estrutura genética de suas populações. O conhecimento da distribuição da variabilidade genética existente em populações naturais de espécies ameaçadas é fundamental para o planejamento de sua conservação. $E$. pedicellatum e E. biflorum são espécies conhecidas por apenas uma população cada, ambas ocorrendo fora de Unidades de Conservação, e, desta forma, criticamente ameaçadas de extinção. E. subsecundum é mais bem distribuída, apresentando algumas populações protegidas. As três espécies apresentam propagação vegetativa e aparentemente o estabelecimento de plântulas nas populações é um evento raro. Foram amostradas quatro populações de E. subsecundum ao longo de $200 \mathrm{~km}$, além das populações de E. biflorum e E. pedicellatum. Toda a amostragem foi estruturada em 
nível de agrupamentos de plantas dentro de populações, respeitando a distribuição espacial dos indivíduos. Utilizaram-se cinco primers RAPD (Random Amplified Polymorphic DNA) para gerar aproximadamente 60 bandas polimórficas para cada espécie. A técnica permitiu observar que cada indivíduo amostrado apresenta um genótipo diferente (com exceção de um clone encontrado para E. biflorum), evidenciando uma variabilidade anteriormente subestimada pelo hábito clonal das plantas, pela sua morfologia uniforme e pelo tamanho reduzido das populações. A porcentagem de bandas polimórficas, bem como o Índice de Diversidade de ShannonWiener, indicam que a espécie E. subsecundum, de distribuição mais ampla, apresenta maior diversidade genética molecular, seguida de E. biflorum. Através da Análise de Variância Molecular, AMOVA, observoutse que o padrão de distribuição da variabilidade genética molecular varia de espécie para espécie. Forte estruturação genética em nível de agrupamentos de plantas foi detectada para E. biflorum e $E$. pedicellatum. E. biflorum apresenta $16,06 \%$ da variância genética molecular entre agrupamentos $\left(\Phi_{\mathrm{st}}=0,16\right)$, que distam em média $11,6 \mathrm{~m}$ entre si, enquanto $E$. pedicellatum apresenta $8,44 \%$ da variância entre agrupamentos distando em média $88 \mathrm{~m}$ entre si $\left(\Phi_{\mathrm{st}}=0,08\right)$. Já a espécie $E$. subsecundum apresenta $14,52 \%$ da variância entre populações distantes em média $116,6 \mathrm{~km}$ umas das outras $\left(\Phi_{\mathrm{st}}=0,15\right)$. Nas três espécies, as diferenças genéticas moleculares existentes entre os indivíduos do mesmo agrupamento são responsáveis pela maior parte da variabilidade genética molecular total (maior do que $80 \%$ da variabilidade nos três casos). Tais resultados têm implicação direta para a conservação, sendo especialmente úteis para a otimização de coletas para a formação de bancos de germoplasma ex situ. 


\title{
POPULATION GENETIC STRUCTURE OF Encholirium (BROMELIACEAE) AND IMPLICATIONS FOR CONSERVATION
}

\author{
Author: MARCELO MATTOS CAVALLARI \\ Adviser: Profa. Dra. ELIZABETH ANN VEASEY
}

SUMMARY

Encholirium is a Brazilian genus of Bromeliaceae which occurs exclusively in rocky landscapes in areas of Cerrado, Caatinga and Atlantic Forest. It's diversity center is located at Cadeia do Espinhaço, Minas Gerais State, Brazil. Of the 23 species of Encholirium, 12 are not protected by any Conservation Unit, occurring only in non-protected territories. The aim of this work was to generate baseline information to the conservation of three Encholirium species, endemic to the rocky mountains of "Cadeia do Espinhaço" in Minas Gerais state, through its populations genetic analyses. Information on genetic diversity and its distribution has a great potential in devising conservation strategies. E. pedicellatum and E. biflorum are known by only one population, both occurring in non-protected territories, being critically endangered. $E$. subsecundum is more widespread, and some of its populations are protected by Conservation Units. These three species reproduces clonally and seedling recruitment is apparently a rare event in natural populations. Samples of E. subsecundum were collected in four populations along $200 \mathrm{~km}$. E. biflorum and E. pedicellatum were collected in the only known populations. The sampling process was made carefully in order to respect the natural distribution of individuals in "patches" or "colonies" within 
populations. Five Random Amplified Polymorphic DNA (RAPD) primers generated approximately 60 polymorphic bands for each species. This technique demonstrated that there is a single genotype for every individual sampled (except for one clone found in $E$. biflorum). High levels of genetic variability were not expected, due to the clonal growth, homogeneous morphology of the plants, and small populations size. The percentage of polymorphic bands and the Shannon-Wiener diversity index showed that $E$. subsecundum has higher levels of genetic diversity, followed by E. biflorum. The results of an Analysis of Molecular Variance (AMOVA) showed that the populations of $E$. biflorum and E. pedicellatum are strongly struturated at the patches level. In E. biflorum, $16.06 \%\left(\Phi_{\mathrm{st}}=0.16\right)$ of the total genetic diversity resided among the patches of the population, which are, on the average, $11.6 \mathrm{~m}$ separated, whereas in E. pedicellatum $8.44 \%\left(\Phi_{\text {st }}=0.08\right)$ of the total genetic diversity was attributable to the differences among patches, which are, on the average, $88 \mathrm{~m}$ apart. In E. subsecundum, $14.52 \%\left(\Phi_{\mathrm{st}}\right.$ $=0.15)$ of the total genetic diversity resided among populations, which are, on the average, $116.6 \mathrm{~km}$ separated. The results are valuable to the development of conservation strategies, in particular to guide future samplings to compose germoplasm banks. 


\section{INTRODUÇÃO}

O gênero Encholirium, pertencente à subfamília Pitcairnioideae, família Bromeliaceae, ocorre exclusivamente em solos areno-pedregosos ou afloramentos rochosos, podendo ser encontrado nos domímios do Cerrado e da Caatinga, principalmente. No bioma Cerrado, é nos Campos Rupestres da Cadeia do Espinhaço de Minas Gerais que se encontra a maioria das espécies (9 spp.), todas endêmicas destes afloramentos quartzíticos. Normalmente, espécies de Encholirium formam grandes populações, porém restritas a localidades relativamente pequenas quando comparadas com a área total de ocorrência do gênero. As características das flores de Encholirium indicam que estas plantas são polinizadas por beija-flores e/ou morcegos, como a maioria das bromeliáceas. Alguns estudos indicam um sistema de cruzamentos preferencialmente alógamo para determinadas espécies do gênero. É rara a presença de indivíduos jovens isolados em populações de Encholirium, indicando que o estabelecimento de plântulas é difícil para a maioria das espécies. Normalmente, tais plantas apresentam propagação vegetativa, formando grandes touceiras.

Devido à marcante presença de Bromeliaceae na Mata Atlântica, poucos trabalhos com esta família são conduzidos em outros ecossistemas. Os Campos Rupestres, no entanto, têm apresentado grande diversidade e alta taxa de endemismo para este grupo. Neste sentido, a crescente destruição dos diversos ecossistemas poderá conduzir à extinção de espécies ainda pouco estudadas. No caso de Encholirium, a falta de estudos pode ser evidenciada pelo fato de que, dentre as 23 espécies existentes, apenas três delas estão relativamente bem amostradas em herbários. Mais alarmante é o fato de que 12 espécies deste gênero não se encontram protegidas por Unidades de Conservação, estando sujeitas a vários tipos de interferência. Devido à distribuição 
restrita e endêmica da maioria das espécies de Encholirium, este gênero exclusivo do Brasil poderá sofrer grandes perdas nos próximos anos.

Atualmente, o conhecimento da estrutura genética de populações é entendido como etapa fundamental para a realização de programas conservacionistas. Os dados gerados por pesquisas em genética de populações podem ser utilizados para definir unidades de conservação e prioridades para o manejo de recursos genéticos, indicando áreas e populações de maior ou menor importância para a preservação dos táxons em questão e permitindo o desenvolvimento de estratégias efetivas de conservação.

Existem muitas maneiras de se estudar a estrutura genética de populações e verificar o grau de variabilidade existente. Dentre os diversos marcadores moleculares disponíveis atualmente, os marcadores RAPD (sigla em inglês para polimorfismo de DNA amplificado ao acaso) mostram-se uma ferramenta poderosa para a análise da diversidade genética molecular em populações naturais de plantas. A técnica é simples e aplicável a qualquer organismo, uma vez que não é necessário o conhecimento de sequiências-alvo no DNA. Sua maior limitação é sua característica dominante, isto é, o fato de não ser possível distinguir indivíduos heterozogóticos de indivíduos homozigóticos dominantes.

Excoffier et al (1992), pela introdução das estatísticas $\Phi$, proporcionaram uma nova alternativa para o uso de marcadores dominantes. Esta análise de variância, denominada AMOVA, produz estimativas dos componentes de variância análogas às estatísticas F de Wright, sem a necessidade de conhecimento das frequiências alélicas.

Este trabalho teve por objetivo, através da técnica de RAPD e da utilização da AMOVA, caracterizar a diversidade genética molecular existente nas espécies E. biflorum, E. pedicellatum e E. subsecundum, gerando informações úteis para sua conservação. Os objetivos específicos foram:1. verificar se os agrupamentos dentro de populações são formados por um ou poucos clones, como sugerem sua alta densidade de indivíduos em espaço reduzido, seu hábito clonal e sua aparência uniforme; 2. verificar se há divergência genética molecular entre os diversos agrupamentos dentro de populações; 3. verificar se há divergência genética molecular entre as populações de $E$. 
subsecundum; 4. compreender como está distribuída a variabilidade genética molecular de cada espécie; 5. verificar se E. subsecundum, de distribuição mais ampla, apresenta maior diversidade genética molecular do que as duas outras espécies; 6. definir estratégias de amostragem para o estabelecimento de bancos de germoplasma ex situ para cada uma das espécies, de acordo com os resultados obtidos. 


\section{REVISÃO DE LITERATURA}

\subsection{O gênero Encholirium}

A família Bromeliaceae compreende aproximadamente 56 gêneros e 2.885 espécies (Luther, 2000), sendo provavelmente a maior família botânica exclusiva do Novo Mundo (Leme \& Marigo, 1993). Segundo Cronquist (1981), Bromeliaceae é a única família da ordem Bromeliales, subclasse Zingiberidae, classe Liliopsida. De acordo com o sistema APG, Angiosperm Phylogeny Group (Bremer et al., 1998), as bromélias pertencem ao grupo das Comelinóides. Chase et al. (2000) posicionam a família na ordem Poales.

Bromeliáceas podem ser encontradas em praticamente todos os ecossistemas neotropicais, desde o nível do mar, em praias, mangues e restingas, até altitudes de $5.000 \mathrm{~m}$, nos Andes, podendo ser terrestres, epífitas ou rupícolas (Leme \& Marigo, 1993; Medina, 1990). Suas adaptações, algumas das quais únicas no reino vegetal, permitiram tão variada colonização de ambientes. Com ampla distribuição no continente americano, ocorrem desde a região sul dos EUA (latitude $37^{\circ} \mathrm{N}$ ) até a região central da Argentina e Chile (latitude $44^{\circ} \mathrm{S}$ ) (Smith \& Downs, 1974). A única exceção ao padrão de distribuição exclusivamente americano é a espécie Pitcairnia feliciana, encontrada na região da Guiné, na África (Leme \& Marigo, 1993).

Três centros de diversidade são aceitos para a família: o norte dos Andes, com extensões até o México e as Antilhas, o Planalto das Guianas, e o Leste do Brasil (Smith \& Downs, 1974). O Leste do Brasil, representado pela Mata Atlântica, merece destaque por apresentar um grande número de espécies e alto grau de endemismo (Leme \& Marigo, 1993). 
São reconhecidas três subfamílias para Bromeliaceae: Bromelioideae, Pitcairnioideae e Tillandsioideae. A diferenciação entre as três subfamílias é baseada em características morfológicas, tais como tipo de frutos e sementes, margem das folhas e posição do ovário (Smith \& Downs, 1974).

Pitcairnioideae é normalmente referida como a mais primitiva entre as três subfamílias, apresentando hábito terrestre, ovário súpero e escamas (tricomas) não absorventes na maioria dos gêneros (Medina, 1990; Smith, 1989). Os representantes desta subfamília são equipados com sistemas radiculares bem desenvolvidos em relação aos membros das outras duas subfamílias (Forzza, 1997).

Smith \& Downs (1974), reconhecem 731 espécies e 13 gêneros para Pitcairnioideae. Atualmente, 16 gêneros são aceitos, sendo que a maioria deles está relacionada a áreas de vegetação aberta da América do Sul (Forzza, 2001). O planalto das Guianas é considerado o centro de diversidade da subfamília, por apresentar o maior número de gêneros, sendo muitos deles endêmicos (Varadarajan \& Gilmartin, 1988). No Brasil, a subfamília é representada por Encholirium e mais dez outros gêneros (Forzza, 2001).

O gênero Encholirium ocorre exclusivamente em território brasileiro. Sua distribuição geográfica está relacionada à ocorrência de solos areno-pedregosos ou afloramentos rochosos, uma vez que seus representantes vegetam exclusivamente neste tipo de substrato. A grande maioria de suas 23 espécies ocorre no Cerrado e na Caatinga (Forzza, 2001). Dentro do domínio do Cerrado, é nos Campos Rupestres da Cadeia do Espinhaço de Minas Gerais que se encontra a maioria das espécies de Encholirium, sendo registradas nove espécies, todas endêmicas destes afloramentos quartzíticos. Ainda no Cerrado, podem-se encontrar espécies deste gênero nos afloramentos de arenito do Mato Grosso e Mato Grosso do Sul, ou mesmo em solos areno-pedregosos no Estado de Goiás. Já na transição do Cerrado para outras formações vegetacionais, de Minas Gerais a Goiás e Bahia, podem-se encontrar espécies de Encholirium em afloramentos de calcário recobertos por floresta decídua. Estendendo-se desde a porção norte da Serra do Espinhaço até o extremo norte do Piauí, a Caatinga abriga muitas espécies de Encholirium. Entre estas, destaca-se a espécie E. spectabile, popularmente 
conhecida por macambira-de-flecha, cuja distribuição geográfica é a mais ampla e a mais setentrional observada para as espécies do gênero. Apenas duas espécies de Encholirium ocorrem fora dos domínios do Cerrado e da Caatinga: E. horridum e E. gracile, que vegetam nos inselbergs do centro ao norte do Espírito Santo, até o leste de Minas Gerais. Os inselbergs são considerados um ecossistema associado à Floresta Atlântica, apresentando uma flora particular (Forzza 2001; Forzza et al. 2003).

Segundo Forzza (2001), a maioria das espécies de Encholirium forma grandes populações, porém restritas a localidades relativamente pequenas quando comparadas com a área total de ocorrência do gênero. A exigência por habitats específicos pode ser um fator determinante deste padrão. Além disso, de acordo com Forzza (2001), em Encholirium o poder de dispersão de sementes é baixo. A ocorrência de espécies simpátricas de Encholirium é rara. Algumas espécies apresentam simpatria aparente, ocorrendo na mesma localidade, mas estando na realidade separadas por diferenças no habitat. É o caso de E. longiflorum e E. brachypodum, cuja distribuição geográfica é a mesma, e, w entanto, a primeira ocorre unicamente em afloramentos calcários, e a segunda, somente em gnaisse.

As características das flores de Encholirium indicam que estas plantas são polinizadas por beija-flores e/ou morcegos, como a maioria das bromeliáceas. Estudos realizados por Christianini et al., em fase de elaboração, verificaram que tanto beijaflores como morcegos contribuem para a polinização de E. vogelli (Forzza, 2003). Para E. heloisae, os autores verificaram que a polinização é realizada exclusivamente por beija-flores. No mesmo estudo, os autores realizaram autopolinizações artificiais, onde se observou a formação de frutos em quantidade significativamente menor do que através da polinização natural. Além disso, os frutos produzidos eram menores e apresentaram desenvolvimento anômalo, evidenciando que estas duas espécies são parcialmente auto-incompatíveis (segundo os autores, possivelmente um caso de autoincompatibilidade de ação tardia). Tais resultados indicam um sistema de cruzamentos preferencialmente alógamo para estas espécies. Segundo Forzza, informação pessoal, é rara a presença de indivíduos jovens isolados em populações de Encholirium, indicando 
que o estabelecimento de plântulas é difícil para a maioria das espécies. Normalmente, observam-se touceiras formadas por indivíduos perfilhados.

\subsubsection{Encholirium biflorum (Mez) Forzza}

Esta espécie foi descrita por Mez em 1894 como pertencente ao gênero Dyckia. Forzza (2001), posicionou a espécie no gênero Encholirium principalmente pela presença de escapo terminal (comum a Encholirium e inexistente em Dyckia) e pelo seu posicionamento em Encholirium ser mais estável em cladogramas obtidos por análise filogenética.

Encholirium biflorum é a espécie de menor porte do gênero, com rosetas de 4 a $11 \mathrm{~cm}$ de diâmetro, e com altura máxima (quando florida) de $32 \mathrm{~cm}$ (Figura 1). Suas folhas são secundas, verdes na face adaxial e cinéreas na abaxial, raramente aculeadas. Sua inflorescência, do tipo racemo, traz apenas de duas a cinco flores (Forzza, 2001). As plantas são encontradas em solo areno-pedregoso, isoladas ou formando pequenas touceiras. Raramente encontram-se indivíduos floridos na natureza. Entretanto, os exemplares depositados em herbários sugerem que esta espécie floresce entre os meses de outubro e janeiro, principalmente.

Todos os exemplares desta espécie que estão em herbários parecem ser

provenientes da mesma localidade, situada nos Campos Rupestres do Planalto de Diamantina. Há uma coleta, entretanto, registrada para a Serra do Cipó, distante algumas centenas de quilômetros. Conforme Forzza (2001), o autor desta coleta, Schwacke, deve ter se enganado ao registrá-la para a Serra do Cipó, uma vez que registrou, na mesma data, uma outra coleta para o Planalto de Diamantina. Esta outra coleta foi para a espécie E. pedicellatum, que realmente ocorre em local próximo da população de E. biflorum no Planalto de Diamantina, sendo muito provável que tenha havido confusão por parte de Schwacke. A única população de E. biflorum conhecida pela ciência está situada em uma área muito restrita, em propriedade particular, à beira da Estrada DiamantinaBiribiri, conforme Forzza (2001). Desta forma, E. biflorum é uma espécie endêmica e restrita, sujeita a diversos tipos de distúrbio. 


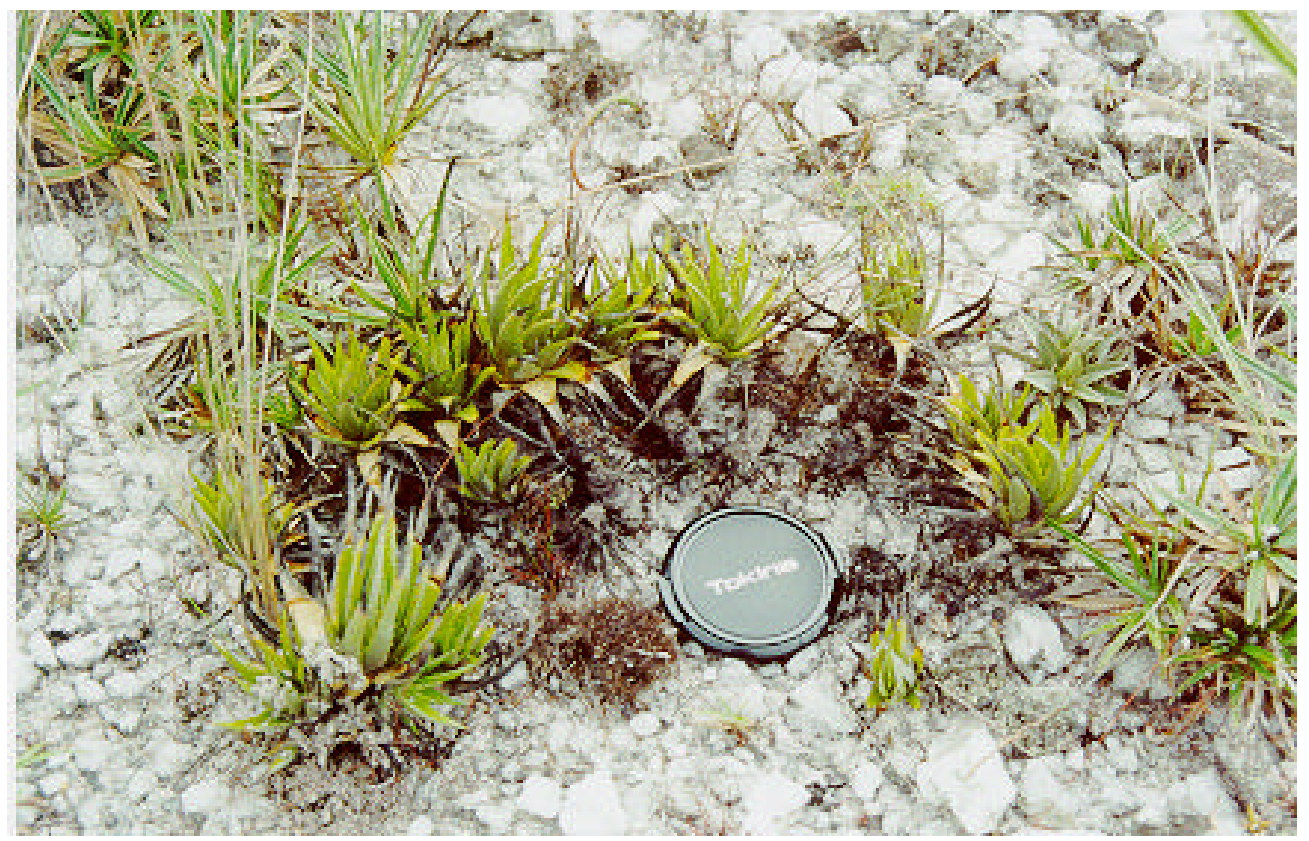

Figura 1 - Touceira de Encholirium biflorum no habitat

Segundo Forzza, informação pessoal, não é conhecido o agente polinizador desta espécie. Sabe-se, porém, que grande maioria das espécies de Bromeliaceae é polinizada por morcegos ou beija-flores.

Forzza et al. (2003), classificaram as espécies de Encholirium de acordo com as categorias propostas pela IUCN (World Conservation Union). Baseados em conhecimento acumulado sobre distribuição geográfica das espécies, tamanho das populações e à representatividade em herbários, os autores verificaram que E. biflorum não possui nenhuma população protegida por Unidades de Conservação, sendo classificada pelos autores como espécie "em perigo", i.e., táxon que está enfrentando, em futuro próximo, alto risco de extinção na natureza. 


\subsubsection{Encholirium pedicellatum (Mez) Rauh}

Encholirium pedicellatum é uma espécie endêmica do Planalto de Diamantina, de área de ocorrência muito restrita. É uma planta relativamente pequena, com rosetas de até $16 \mathrm{~cm}$ de diâmetro (Figura 2). Suas folhas são fortemente cinéreas nas duas faces, e aculeadas. Quando florida, pode atingir $70 \mathrm{~cm}$ de altura. Sua inflorescência é do tipo racemo, trazendo pequenas flores esverdeadas. Suas sementes apresentam alas arredondadas. As plantas vegetam diretamente sobre afloramentos rochosos, especialmente nas fendas onde se acumulam areia e detritos, isoladas ou em pequenas touceiras. De acordo com o material depositado em herbários, a floração desta espécie parece ocorrer entre os meses de janeiro e fevereiro (Forzza, 2001).

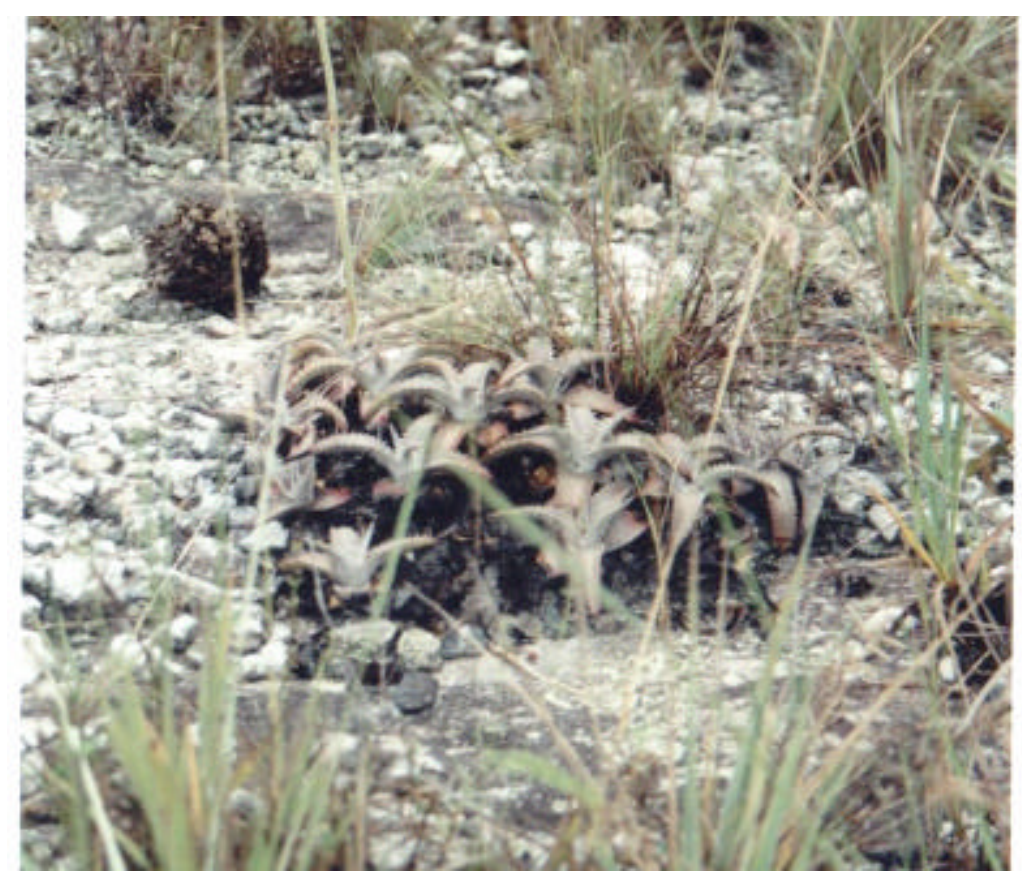

Figura 2 - Touceira de Encholirium pedicellatum no habitat 
Conforme Forzza (2001), todas as coleções de herbário são provenientes de uma única população, que ocorre em área muito restrita, próxima à estrada Diamantina-Biribiri, em propriedade particular.

Segundo Forzza, informação pessoal, também não é conhecido o agente polinizador desta espécie.

De acordo com Forzza et al. (2003), E. pedicellatum não está protegida por nenhuma Unidade de Conservação, sendo classificada como espécie "criticamente em perigo", i.e., táxon que está enfrentando, em futuro imediato, risco extremamente alto de extinção na natureza.

\subsubsection{Encholirium subsecundum (Baker) Mez}

Esta espécie foi descrita por Baker como Dyckia subsecunda, sendo transferida para o gênero Encholirium por Mez em 1896 (Forzza, 2001).

Encholirium subsecundum é uma espécie de maior porte (Figura 3), podendo atingir até $2 \mathrm{~m}$ de altura quando em floração. É uma das espécies com hábito mais robusto e de maior porte dentre as espécies do gênero que ocorrem na Cadeia do Espinhaço. Suas folhas são verdes ou cinéreas, com margem fortemente aculeada. Sua inflorescência traz inúmeras flores verdes. Apresenta sementes com alas falciformes. Indivíduos em floração podem ser encontrados durante quase todo o ano, principalmente de dezembro a março. A frutificação também pode ser observada ao longo de quase todo o ano (Forzza, 2001). 


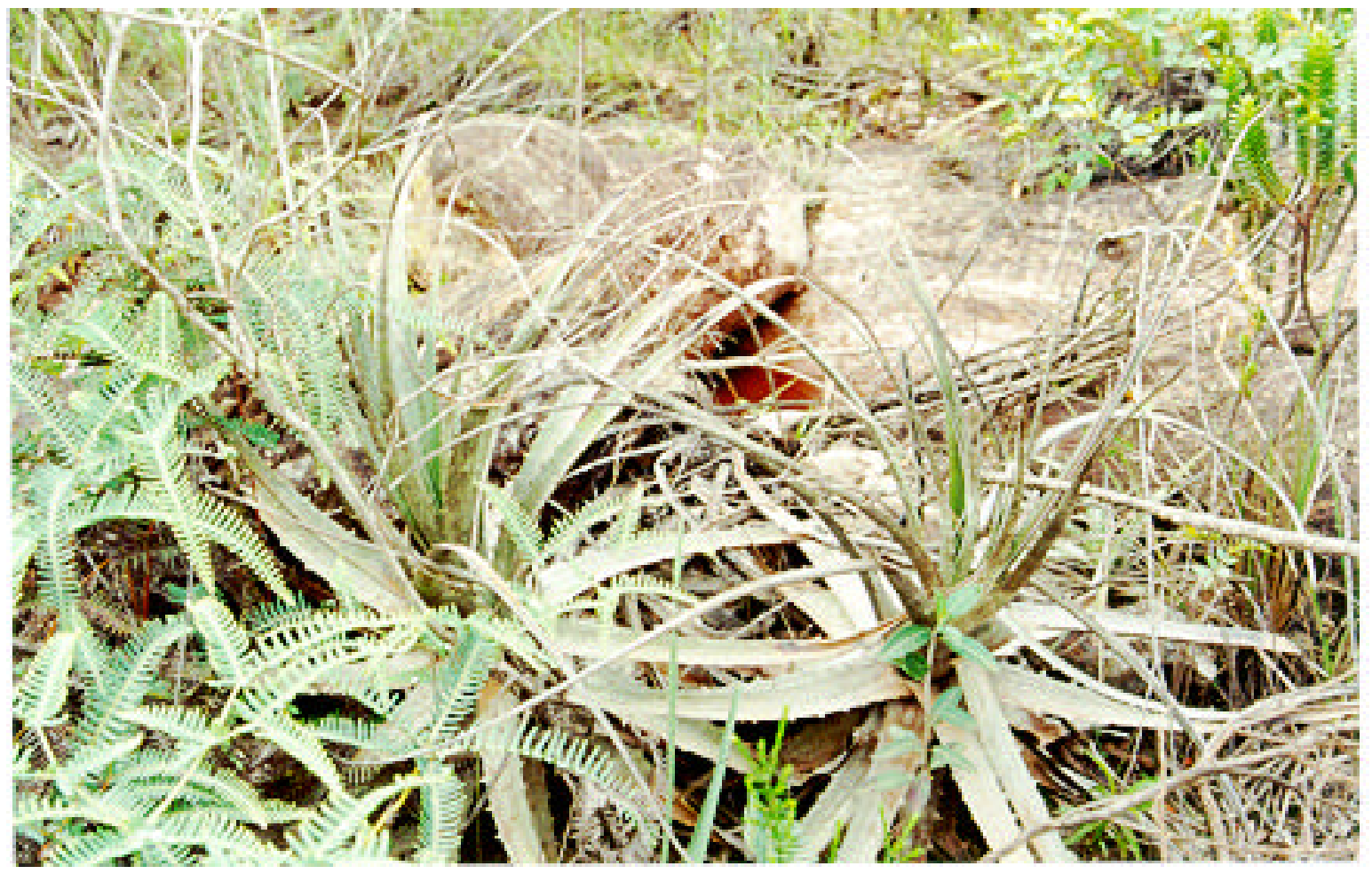

Figura 3 - Encholirium subsecundum no habitat

E. subsecundum é endêmico da porção mineira da Cadeia do Espinhaço, vegetando diretamente sobre afloramentos rochosos, normalmente formando grandes touceiras (Forzza, 2001). No entanto, diferentemente das demais espécies de Encholirium, que são restritas a uma ou duas serras, E. subsecundum é amplamente distribuída, tendo como limite sul de ocorrência o município de Pedro Leopoldo, chegando até Itacambira e Juramento, ao norte. Além de sua maior distribuição geográfica, esta espécie possui um padrão de distribuição de indivíduos diferente das demais espécies do gênero que ocorrem na região, apresentando indivíduos distribuídos em muitos pontos ao longo das serras, em apenas alguns locais havendo a formação de populações mais densas (nas demais espécies, observam-se a formação de poucas populações muito densas e muito restritas). 
E. subsecundum é polinizada por morcegos, e sua flores apresentam protoginia, um mecanismo que evita a autofecundação (Sazima et al., 1989),

Esta espécie possui populações tanto em áreas não protegidas como dentro de Unidades de Conservação, sendo considerada pelos autores como uma espécie "vulnerável", i.e., que está enfrentando, em médio prazo, alto risco de extinção na natureza (Forzza et al., 2003).

\subsection{Encholirium e extinção}

Devido à marcante presença da família Bromeliaceae na Mata Atlântica, poucos trabalhos com esta família são conduzidos em outros ecossistemas. Os Campos Rupestres, no entanto, têm apresentado grande diversidade e alta taxa de endemismo para esta família (Wanderley \& Martinelli, 1987). A vegetação dos Campos Rupestres apresenta certa uniformidade, escondendo uma das floras mais ricas do Brasil, principalmente em espécies de bromélias (Leme \& Marigo, 1993). Assim, a crescente destruição dos diversos ecossistemas poderá conduzir à extinção de espécies ainda pouco estudadas.

No caso de Encholirium, a falta de estudos pode ser evidenciada pelo fato de que, dentre as 23 espécies existentes, apenas três estão relativamente bem amostradas em herbários, enquanto sete espécies são conhecidas apenas pelas coleções-tipo, i.e., nunca mais foram coletadas. Mais alarmante é o fato de que 12 espécies deste gênero não se encontram protegidas por nenhuma Unidade de Conservação (Forzza et al., 2003), isto é, ocorrem apenas fora delas, estando sujeitas a vários tipos de interferência. Devido à distribuição restrita e endêmica da maioria das espécies de Encholirium, este gênero exclusivo do Brasil poderá sofrer grandes perdas nos próximos anos. A maioria das espécies de Encholirium não protegidas por Unidades de Conservação está restrita a afloramentos de calcário ou granito que estão em processo acelerado de degradação. A extração de calcário é uma grave ameaça a espécies como E. luxor e E. longiflorum, enquanto as espécies dos inselbergs do Espírito Santo, E. gracile e E. horridum estão seriamente ameaçadas pela extração de granito e conseqüente destruição de seu habitat 
(Forzza, 1998; Forzza et al., 2003). A maior ameaça a espécies não protegidas por Unidades de Conservação, tais como E. biflorum, E. pedicellatum, E. scrutor e E. reflexum, é o fato de suas populações estarem em propriedades particulares, isto é, sujeitas a vários tipos de distúrbio. No caso destas espécies, pouquíssimas populações são conhecidas, de modo que qualquer roça, criação de animais ou "benfeitoria" realizada pelo proprietário do terreno pode conduzir a espécie à extinção. Mesmo protegidas em Unidades de Conservação, espécies como E. heloisae e E. vogelli possuem muitas populações ameaçadas, principalmente pela presença de gado e de turistas. O recente asfaltamento da Rodovia MG-010, na Serra do Cipó, tornou as populações ainda mais vulneráveis (Figura 4). 


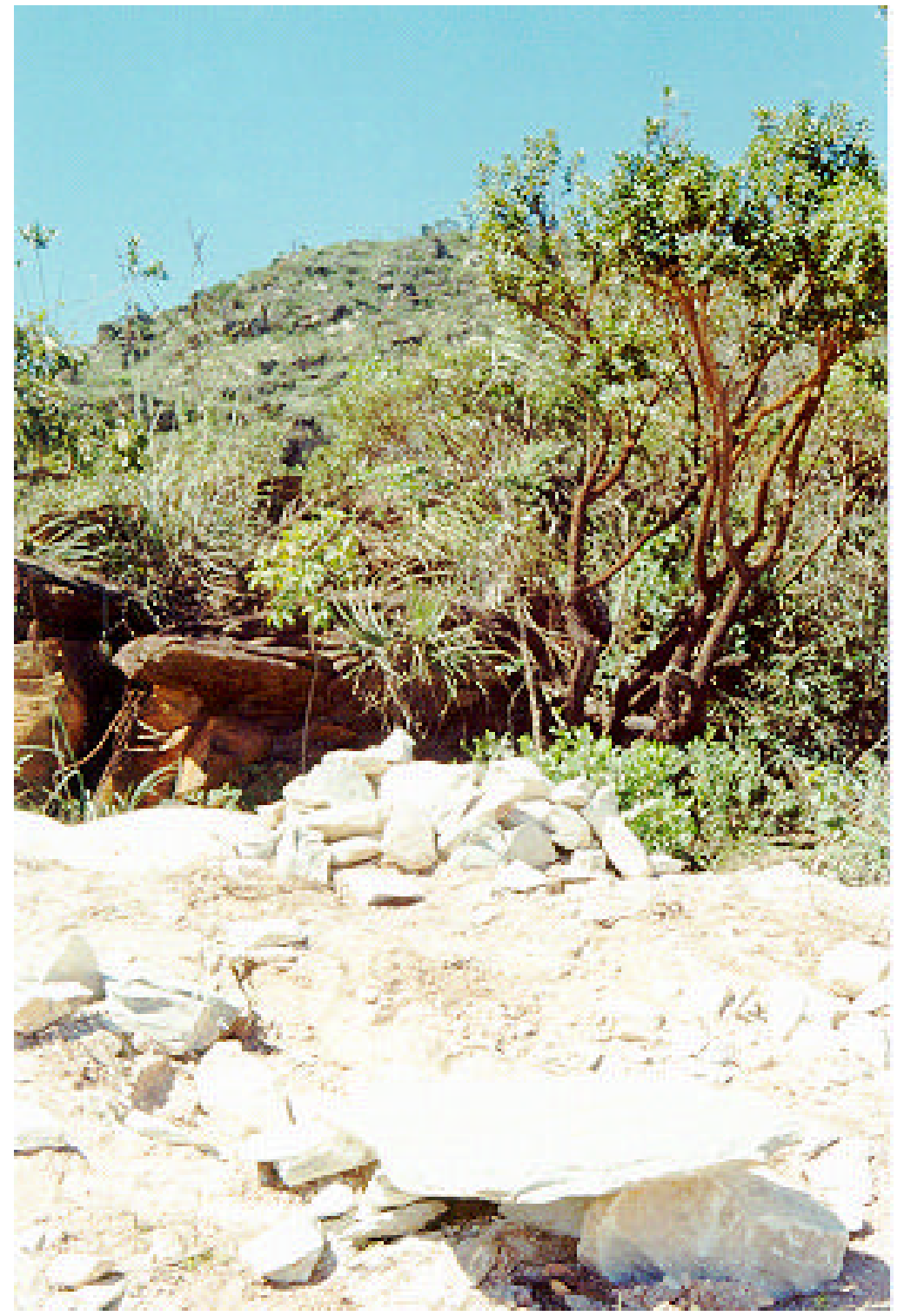

Figura 4 - Extração de pedras em população de Encholirium subsecundum, dentro da Área de Proteção Ambiental da Serra do Cipó, em local recém aberto pelas obras de asfaltamento da MG-010 


\subsection{A importância da manutenção da variabilidade genética}

Nas últimas décadas, a extinção de variadas formas de vida tem aumentado consideravelmente. Acredita-se que aproximadamente $25 \%$ das espécies de plantas vasculares existentes serão extintas nos próximos 50 anos (Kala, 2000). Muitos fatores estão envolvidos com a extinção de espécies, como a destruição de habitats e consequiente fragmentação de populações (Matocq \& Villablanca, 2001).

A fragmentação de uma população expõe uma determinada espécie aos efeitos da endogamia e da deriva genética, processos que ocorrem naturalmente em qualquer população, mas que não trazem prejuízos para populações grandes. Os efeitos genéticos da fragmentação de populações estão diretamente relacionados com os processos estocásticos associados a populações de tamanho reduzido (Bouzat, 2001). Populações pequenas e isoladas são mais sujeitas aos efeitos da endogamia e da deriva genética, apresentando normalmente menor variabilidade genética como conseqüência (Fischer, 1930; Wright, 1931, para um tratamento didático, ver Hartl \& Clark, 1997; para exemplos recentes, ver, entre outros, Jaggi et al., 2000; Jones et al., 2001; Tlansley \& Brown, 2000).

A variabilidade genética é de importância fundamental para o potencial evolutivo de uma espécie, e determina suas chances de sobrevivência em longo prazo (Fleishman et al., 2001; Jones et al., 2001). Trata-se da "matéria-prima" que possibilita as mudanças evolutivas de uma espécie (Mamuris et al., 2001; Pither et al., 2003). Populações com pouca variabilidade genética podem ser incapazes de responder às mudanças ambientais (Jones et al., 2001; Matocq \& Villablanca, 2001; Sharma et al., 2000; Sharma, 2001; Tansley \& Brown, 2000). A perda da variabilidade genética resulta em baixo potencial evolutivo (Holsinger \& Gottlieb, 1991) e provoca a redução do fitness (adaptabilidade), tanto do indivíduo quanto da população (Bouzat, 2001; Koppitz, 1999; Matocq \& Villablanca, 2001). A redução da variabilidade genética pode conduzir uma espécie à extinção (Bouzat, 2001; Sharma, 2001; Sharma et al., 2000), sendo, portanto, uma das principais ameaças à existência de uma espécie (Jaggi et al., 2000; Tansley \& Brown, 2000). 
Apesar das assertivas acima, algumas considerações devem ser feitas. Primeiramente, deve-se ressaltar que em muitos casos não há relação entre o tamanho da população e o nível de variabilidade genética. Populações em fragmentos pequenos normalmente apresentam variabilidade genética reduzida (Brown, 1999; Tansley \& Brown, 2000), mas em certos casos pode ser observado o contrário (Brown, 1999; Godt et al., 1995; James \& Ashburner; 1997). A variabilidade genética nem sempre está relacionada com a extensão da distribuição geográfica da espécie. Espécies raras ou endêmicas, de distribuição restrita, normalmente apresentam variabilidade genética reduzida, por apresentarem populações pequenas e isoladas (Brown, 1999; Tansley \& Brown, 2000; Waller et al., 1987), mas podem-se encontrar exceções a este padrão (Coates \& Atkins, 2001). Por fim, a condição de pequena variabilidade genética ou de distribuição geográfica restrita não necessariamente implica em risco de extinção, ou melhor, tal condição pode não ter sido causada por ação antrópica. Muitos endemismos, por exemplo, encontram sua explicação em fatos históricos conhecidos, como refúgios de glaciações (Futuyma, 1997). Muitas espécies parecem "conviver" com a baixa variabilidade, ou com populações reduzidas de distribuição muito restrita (Coates \& Atkins, 2001; Fleishman et al., 2001). Em muitos casos, devido à falta de registros mais antigos, é impossível afirmar se a reduzida variabilidade genética encontrada em determinada espécie é devida à flutuações demográficas recentes ou se se trata de um padrão histórico da espécie (Matocq \& Villablanca, 2001).

Independentemente do padrão de diversidade genética de cada espécie, a manutenção da variabilidade genética é considerada essencial para a preservação do potencial evolutivo de espécies (Fleishman et al., 2001) e para sua sobrevivência em longo prazo (Tansley \& Brown, 2000). Muitos programas de conservação de plantas raras ou ameaçadas visam manter os níveis existentes de variabilidade genética, evidenciando a importância de pesquisas em genética de populações para a conservação de espécies (James \& Ashburner, 1997). Conforme Zucchi (2002), o sucesso de qualquer programa de conservação depende do conhecimento da variabilidade genética existente na espécie. 


\subsection{Estrutura genética de populações}

Populações de plantas são compostas por genótipos distribuídos de forma estruturada no espaço e no tempo (Loveless \& Hamrick, 1984). Esta estruturação, segundo os autores, pode se manifestar entre diferentes populações ou entre grupos dentro de populações. A partição da variabilidade genética entre e dentro de populações de uma determinada espécie é resultado de processos dinâmicos de fluxo gênico, seleção, endogamia, deriva genética e mutação (Hartl \& Clark, 1997). A estrutura populacional de uma espécie é resultado da ação e das interações de uma série de mecanismos evolutivos e ecológicos (Martins, 1987).

Os fatores que afetam a reprodução e fluxo gênico são particularmente determinantes da estrutura genética de populações (Loveless \& Hamrick, 1984). Polinizadores como morcegos e beija flores, por exemplo, devido à sua capacidade de vôo, promovem o aumento da variabilidade dentro de populações, enquanto diminuem a divergência entre populações ao mantê-las ligadas por fluxo gênico. Da mesma forma, sementes dispersas pelo vento promovem o deslocamento de alelos dentro da população e eventualmente entre populações. O limitado fluxo gênico mesmo dentro de populações pode levar à formação de pequenos grupos de indivíduos geneticamente mais similares, de modo que uma população pode ser constituída de várias subpopulações geneticamente diferenciadas (Fischer et al., 2000).

O sistema reprodutivo preferencial (autogamia ou alogamia), também contribui com a determinação da estrutura genética (Loveless \& Hamrick, 1984). Em espécies preferencialmente alógamas, espera-se encontrar alta diversidade dentro de populações e baixa diversidade entre populações. Já em espécies autógamas, as populações apresentam pouca diversidade de genótipos, mas são bastante divergentes

entre si. Outros fatores relacionados ao sistema reprodutivo que afetam a estrutura genética de populações são a morfologia floral (flores monóicas, dióicas ou hermafroditas) e grau de sexualidade (reprodução sexuada, assexuada, apomixia, proporção entre sexos). 
Além do sistema reprodutivo, a distribuição geográfica das populações (distribuição ampla ou restrita, populações próximas ou distantes, heterogeneidade de ambientes) e os componentes da história vital (taxas reprodutivas, mortalidade, duração do ciclo vital, esforço reprodutivo) também são determinantes da estrutura genética de populações. Detalhes sobre os fatores que afetam a estrutura genética de populações podem ser encontrados nas revisões realizadas por Martins (1987), Loveless \& Hamrick (1984) e Hamrick (1982).

\subsection{Estrutura genética de populações de plantas clonais}

Espécies que possuem propagação vegetativa apresentam particularidades em relação à estrutura genética de suas populações, e seu estudo merece atenção especial devido à formação de clones e à dificuldade de identificá-los. A reprodução assexuada possui importância evolutiva por transmitir os genótipos integralmente aos perfilhos, transmitindo assim a variância genética total, enquanto que a reprodução sexuada transmite apenas a variância genética aditiva. A implicação disto é que a seleção natural é mais eficiente numa população assexual, uma vez que a taxa de progresso é determinada mais pela variância genotípica (variância genética total) do que pela variância gênica (variância genética aditiva) (Crow \& Kimura, 1970). Em curto prazo, em ambientes relativamente estáveis, a reprodução assexuada pode ser vantajosa em relação à reprodução sexuada, pois as combinações genotípicas favoráveis são mantidas ao longo das gerações.

A estratégia de crescimento clonal de uma espécie pode ser classificada como "falange" (phalanx, produção de brotações laterais curtas que leva à formação de touceiras compactas) e "guerrilha" (guerrilla, produção de longos estolões que permitem maior espaçamento entre perfilhos) (Lovett Doust, 1981).

Conforme Cook (1983), em espécies clonais dois níveis de organização podem ser reconhecidos: genetos (genets) e rametos (ramets). Um geneto compreende todos os indivíduos geneticamente idênticos, membros de um clone, originados de um único zigoto. Já um rameto constitui-se numa parte potencialmente independente de um 
geneto (no caso de Bromeliaceae, os rametos se apresentam na forma de rosetas perfilhos- com fenologia independente das demais rosetas do mesmo geneto). Como a variação genética ocorre apenas entre genetos (exceto nos casos de mutação somática), o tamanho efetivo das populações não pode ser determinado pela simples contagem dos rametos, sendo necessário identificar os genetos (Persson \& Gustavsson, 2001). Por exemplo, para o arbusto australiano Haloragodendrom lucasii, Sydes \& Peakall (1998), relatam terem encontrado, através de escavações, estolões com mais de $6 \mathrm{~m}$ de comprimento, com perfilhos de metro em metro. Segundo os autores, este hábito torna impossível identificar os genetos no campo, dificultando, por exemplo, coletas para a formação de bancos de germoplasma.

Em espécies com reprodução assexuada, portanto, é esperado um menor número de genótipos em relação ao número de indivíduos observados na população, uma vez que muitos deles podem pertencer ao mesmo geneto. Sydes \& Peakall (1998), relatam que em uma das populações estudadas, onde o número de rametos foi estimado em mais de 500, apenas três genetos foram encontrados. Persson \& Gustavsson (2001), identificaram apenas 29 diferentes genótipos entre 129 plantas de Vaccinium vitis-idaea analisadas. Tais números, porém, devem ser observados com cautela. A estratégia de amostragem tem influencia direta na relação entre o número de genótipos identificados e o número de amostras. Por exemplo, coletar ao longo de transectos, coletar todos os indivíduos de uma população e coletar apenas indivíduos fisicamente separados uns dos outros são três métodos de amostragem que resultam em diferentes proporções de genetos/ rametos.

Muitas pesquisas com espécies clonais relatam uma baixa participação da reprodução sexuada na formação das populações. Alguns exemplos podem ser encontrados nos trabalhos de Ayres \& Ryan (1999), Esselman et al. (1999) e Persson \& Gustavsson (2001), entre outros. Sydes \& Peakall (1998), por exemplo, relatam que a reprodução sexuada em Haloragodendrom lucasii é um evento raro, nunca tendo sido observada a produção de sementes desde a redescoberta da espécie em 1986. Os autores sugerem que o hábito clonal em espécies auto-incompatíveis ou dióicas pode limitar a 
produção de sementes quando o fluxo de pólen ocorre entre rametos do mesmo geneto (gitoginia), isto é, entre clones.

Conforme Persson \& Gustavsson (2001), como normalmente a contribuição das sementes para a formação de populações é um evento raro em espécies clonais, espera-se que estas espécies apresentem menos diversidade genética do que espécies com reprodução exclusivamente sexuada. Segundo Loveless \& Hamrick (1984), espera-se que populações de plantas clonais sejam dominadas por um ou poucos genótipos localmente adaptados. Vários estudos, porém, têm revelado níveis de diversidade genética molecular em espécies clonais similares aos encontrados em espécies de reprodução sexuada (Fischer et al, 2000; Kreher et al., 2000). Persson \& Gustavsson (2001), por exemplo, relatam que a variabilidade genética molecular encontrada dentro das populações de Vaccinium vitis-ideae, uma espécie clonal, foi similar àquela normalmente relatada para plantas de reprodução exclusivamente sexuada.

Outra particularidade da estrutura genética de plantas clonais está relacionada aos efeitos da deriva genética. A deriva genética, que diminui a variabilidade genética de maneira inversamente proporcional ao tamanho efetivo da população a cada geração, é menos pronunciada nestas espécies (Fischer et al., 2000). Como a deriva genética só ocorre através da morte de uma geração e da sua substituição pela geração subseqüente, a manutenção dos diferentes genótipos através de seus perfilhos contribui para a conservação da variabilidade genética na população ao longo dos anos (Ayres \& Ryan, 1999).

\subsection{Implicações do conhecimento da estrutura genética de populações na conservação de espécies}

A preservação da diversidade genética se tornou o objetivo da maioria dos programas de conservação, e conhecer a distribuição desta diversidade entre e dentro de populações naturais é o primeiro passo (Bekessy et al., 2002). O conhecimento do modo como a variação genética de uma espécie está distribuída entre e dentro de suas 
populações é essencial para a sua conservação (Reis, 1999). Atualmente, o conhecimento da estrutura genética de populações é entendido como etapa fundamental para a realização de programas conservacionistas (Mamuris et al., 2001; Martins, 1988, Sharma et al., 2000). Os dados gerados por pesquisas em genética de populações podem ser utilizados para definir unidades de conservação e prioridades para o manejo de recursos genéticos (Coates \& Atkins, 2001; Fleishman et al., 2001; Jaggi et al., 2000; Jones et al., 2001; Tansley \& Brown, 2000), indicando áreas e populações de maior ou menor importância para a preservação dos táxons em questão e permitindo o desenvolvimento de estratégias efetivas de conservação (Holsinger \& Gottlieb, 1991). A determinação da diversidade genética e da estrutura de populações naturais de plantas é também fundamental para o estabelecimento de formas de exploração econômica racional Lacerda et al. (2001).

A conservação de espécies depende da manutenção de sua diversidade genética no habitat natural (in situ) e de reservas genéticas ex situ, ou bancos de germoplasma. Bancos de germoplasma podem ser compostos de coleções de plantas vivas, sementes ou cultura de tecidos. A implantação de reservas genéticas deve ser considerada como parte de uma estratégia global de preservação, e esta necessidade é premente, tendo em vista a velocidade com que os habitats vêm sendo destruídos ou transformados pelas diversas atividades humanas (Martins, 1988).

Uma vez que o objetivo básico da preservação in situ é a manutenção de variabilidade genética suficiente para possibilitar evolução contínua em ecossistemas (Martins, 1988), o maior número de populações deve ser preservado, abrangendo toda a distribuição geográfica e toda a amplitude ecológica da espécie. Analogamente, para a conservação ex situ, bancos de germoplasma devem representar ao máximo a variabilidade genética da espécie. No entanto, na grande maioria dos casos, os recursos e o tempo são limitados, sendo praticamente impossível preservar todas (ou ao menos uma grande parte) as populações, bem como formar bancos de germoplasma completos. No caso da conservação $e x$ situ, existe ainda a dificuldade de manutenção destas coleções, havendo limitações de toda sorte, inclusive de espaço disponível nas instituições. 
Desta forma, o estudo da estrutura genética de populações, aliado a outras áreas da biologia, pode fornecer informações preciosas para o planejamento e execução de programas de conservação de uma espécie. Para a conservação in situ, podem-se definir populações ou regiões prioritárias para conservação, de acordo com os padrões de distribuição da variabilidade genética observados para a espécie. Para isto, é fundamental conhecer quais são os locais ou populações onde a variabilidade genética de uma espécie está concentrada. Da mesma forma, para a conservação ex situ, o conhecimento da estrutura genética de populações determina quais e quantos indivíduos de quais e quantas populações devem ser amostrados. No caso de limitação de espaço, por exemplo, pode fazer muita diferença se a espécie estará bem amostrada com apenas poucos indivíduos.

Um exemplo de como o conhecimento da estrutura genética das populações pode orientar os projetos de conservação pode ser dado através da pesquisa de Jones et al. (2001), com uma espécie de Liliaceae nativa da Grã-Bretanha. Os autores sugeriram, após a análise de seus resultados, que as populações devem ser mantidas isoladas, pois cruzamentos artificiais entre plantas de diferentes populações, por vezes recomendados, neste caso destruiriam a variabilidade inter-populacional, bem como as adaptações locais e o valor científico da história genética destas populações.

$\mathrm{Na}$ Austrália, estudos em genética de populações têm oferecido informações valiosas para o desenvolvimento de estratégias de manejo de recursos genéticos in situ e ex situ, e para a definição de prioridades de manejo e de pesquisa (Coates \& Atkins, 2001). Para várias espécies de plantas, após a compreensão de como sua variabilidade genética estava distribuída, determinaram-se diversos fragmentos que atualmente são considerados "unidades de manejo para conservação".

Em estudo conduzido por Rossetto et al., em 1999, também realizado na Austrália, para duas espécies ameaçadas de eucalipto, Eucalyptus phylacis e E. dolorosa, diferentes estratégias de conservação foram propostas, baseadas na análise da estrutura genética das populações destas plantas. Para E. phylacis, a análise revelou que a única população conhecida trata-se na realidade de um único clone. Os autores propuseram a realização de pesquisas a respeito da biologia reprodutiva desta espécie e a criação de 
um banco de germoplasma ex situ, para garantir a preservação da espécie no caso de incêndios, que a levariam à extinção. Já para E. dolorosa, os autores detectaram variabilidade genética e produção esporádica de sementes viáveis. Além da conservação ex situ, os autores propuseram reintroduções em áreas de onde a espécie foi provavelmente extinta.

Em uma pesquisa realizada por Fleishman et al. (2001), na Califórnia, EUA, através da análise da estrutura genética das populações remanescentes de uma planta ameaçada de extinção, Cordylanthus palmatus, foi possível verificar que reintroduções de indivíduos provenientes dos fragmentos maiores nos fragmentos menores não seria benéfica, uma vez que a variabilidade genética não se mostrou diretamente proporcional ao tamanho do fragmento, como se imaginava antes da conclusão da pesquisa. Os autores apontam uma das menores populações como prioritária para conservação. Esta população, além de apresentar maior variabilidade genética do que as demais, não está protegida, estando sujeita a diversos distúrbios.

Jimenez et al. (2002), estudaram a espécie ameaçada Antirrhinum subbaeticum, conhecida por apenas quatro populações. Os resultados mostraram que a maior parte da variabilidade genética está entre populações, isto é, que as populações são bastante divergentes entre si. Como estratégia de conservação, os autores sugerem a criação de um banco de germoplasma, formado a partir de amostras de todas as populações. Resultados e propostas similares podem ser encontrados no trabalho de Bekessy et al. (2002) com populações de Araucaria araucana. Os autores identificaram populações altamente divergentes do ponto de vista genético. As duas populações mais divergentes são também as mais antropizadas e vulneráveis, exigindo prioridade de conservação. Para a preservação ex situ, os autores sugerem que o germoplasma de diferentes populações seja coletado, e que sejam propagados separadamente, a fim de manter os padrões de diversidade genética observados na natureza. Da mesma forma, Martin \& Bermejo (2000) propõem coleções ex situ de Rosmarinus tomentosus, espécie ameaçada, endêmica do sul da Espanha, a partir de sementes coletadas em todas as regiões, populações e agrupamentos. Para conservação in situ, os autores ressaltam a importância da manutenção de cada agrupamento. 
Tansley \& Brown (2000), em pesquisa realizada na África do Sul, revelaram através da estrutura genética das populações de uma planta rara e ameaçada, Leucadendron elimense, que pequenos fragmentos abrigam alta variabilidade genética nesta espécie. Os autores então ressaltaram que a delimitação de pequenas reservas, neste caso, seria mais eficiente do ponto de vista conservacionista do que a implantação de apenas uma grande reserva (que não abrigaria toda a variabilidade), evidenciando o fato de que tais pesquisas podem gerar informações cruciais para a tomada de decisões no que tange à demarcação de unidades de conservação.

Conforme Martins (1988), a Genética Evolutiva tem a oferecer aos pesquisadores envolvidos na preservação de recursos genéticos um conjunto de princípios fundamentais no equacionamento de estratégias de preservação que visam a manutenção ou estabelecimento de condições que permitam a continuidade dos processos evolutivos. E a possibilidade dessa continuidade é condição essencial não só à sobrevivência das plantas e animais, como à do próprio homem.

\subsection{Amostragem para estudo da estrutura genética de populações e para a formação de coleções $e x$ situ}

Para a realização de análises da estrutura genética de populações, bem como para a formação de coleções ex situ para fins conservacionistas, é preciso realizar uma amostragem (coleta de indivíduos, tecidos, propágulos ou sementes) que represente ao máximo a distribuição da diversidade genética molecular da espécie. A definição ou delimitação da amostra a ser tomada é uma questão complexa. Se os padrões de distribuição da diversidade genética da espécie em questão fossem conhecidos a priori, uma estratégia ótima poderia ser desenvolvida, mas na prática tal informação é normalmente limitada ou não disponível antes da amostragem (Frankel et al., 1995). A problemática da amostragem pode ser resumida pelas perguntas "quantas e quais populações devem ser amostradas?" e "quantos indivíduos devem ser amostrados por população?". Obviamente, quanto mais indivíduos e quanto mais populações forem amostradas, mais bem representada estará sendo a espécie. Porém, normalmente há 
limitações de ordem prática e financeira, sendo necessário estabelecer critérios para diminuir o tamanho das amostras mantendo a representatividade da espécie. Por exemplo, em espécies com populações uniformes e interligadas por fluxo gênico, não é necessário amostrar todas as populações. Analogamente, um maior número de populações deve ser coletado quando há diversidade entre elas. Quanto maior a diversidade entre populações, maior a necessidade de amostragem em todas as populações. No entanto, a diversidade genética normalmente não é conhecida antes da amostragem. Alguns fatores podem sugerir que há diversidade entre as populações, tais como a presença de ecótipos locais, o isolamento geográfico entre as populações e o próprio sistema de cruzamento (por exemplo, populações de plantas autógamas apresentam a maior parte da diversidade entre populações). A observância destes fatores pode auxiliar a decisão do número de populações a serem amostradas. A definição do número de populações a serem amostradas, segundo Frankel et al. (1995), deve ser baseada nos objetivos da pesquisa e nos recursos disponíveis. Um princípio básico é amostrar populações de forma a cobrir toda a amplitude ecológica e geográfica da espécie.

Para a definição do número de indivíduos a ser amostrado em cada população, alguns critérios devem ser observados, uma vez que o ideal seria coletar a população inteira, e isso muitas vezes é inviável. Devem ser coletados mais indivíduos se houver diversidade dentro da população, que pode ser sugerida pela presença de diferentes "agrupamentos" ou "microsites" (Frankel et al., 1995). A diversidade dentro da população também pode ser sugerida pelo sistema preferencial de cruzamentos da espécie (alógamas apresentam maior diversidade dentro de populações) e por sistemas de auto-incompatibilidade.

É possível calcular o efeito da amostragem na "captação" de alelos, baseado em distribuições hipotéticas de freqüências alélicas (Frankel et al., 1995). Para este propósito, o autor afirma que o modelo de alelos neutros de Kimura \& Crow (1964), pode ser utilizado. É através deste modelo que se verifica que o número de alelos numa amostra aumenta proporcionalmente ao logaritmo do tamanho da amostra. Assim, quanto mais se aumenta o tamanho amostral, mais dificilmente será coletado um alelo 
"inédito", e o esforço ou custo de coleta é relativamente maior. Graças a este raciocínio, o número de indivíduos a serem amostrados tem seu limite máximo próximo de 50 (Guerrant, 1992). Apesar desta conclusão ser derivada do modelo de alelos neutros sob condições de equilíbrio para uma específica variação genética, ela pode ser aplicada em muitos outros casos, como em situações de desequilíbrio (Frankel et al., 1995).

Por fim, o procedimento de amostragem deve ser considerado. A amostragem de indivíduos dentro da população pode ser aleatória, orientada para determinado fenótipo, estruturada, hierárquica, etc, de acordo com o objetivo (Frankel et al., 1995). Por um lado, a amostragem aleatória é estatisticamente robusta e desejável. Por outro lado, os objetivos da pesquisa podem requerer amostragens estruturadas. Tais amostragens permitem fazer uma distinção mais acurada dos padrões de dispersão locais, regionais ou em agrupamentos (Loveless \& Hamrick, 1984).

A amostragem estruturada permite verificar se indivíduos mais próximos espacialmente são mais similares entre si, e se existe um padrão de estrutura espacial dentro da população. Perecin (2000), por exemplo, ao estudar a estrutura genética de populações de espinheira-santa, após amostragem estruturada procurou "investigar a ocorrência de estruturação genética espacial em duas das populações amostradas, para estabelecer hipóteses sobre a distribuição genética a nível local, visando inferir possíveis medidas de manejo em áreas de ocorrência desta espécie". Segundo a autora, o conhecimento da estrutura genética espacial é de importância estratégica na amostragem das populações naturais, tanto para conservação como para melhoramento, uma vez que aumenta as chances de amostragem de genótipos não aparentados e permite predizer impactos de coleta.

A amostragem estruturada é essencial para a utilização, por exemplo, da Análise de Variância Molecular - AMOVA (Excoffier et al., 1992). A AMOVA pode informar como a variabilidade genética está distribuída, desde que os diferentes níveis hierárquicos sejam estabelecidos a priori e respeitados no momento da coleta. 
2.8 Técnicas moleculares para o estudo da estrutura genética de populações: RAPD

Existem muitas maneiras de se acessar a estrutura genética de populações e verificar o grau de variabilidade existente em uma determinada espécie (Ferreira e Grattapaglia,1998). O mais simples indicador de variabilidade genética é a própria variabilidade morfológica. Porém, características morfológicas podem ser influenciadas pelo ambiente, apresentando variação contínua e grande plasticidade (Zucchi, 2002). Portanto, para a determinação mais precisa e segura da variabilidade genética, é necessário utilizar características não influenciáveis pelo ambiente. Neste sentido, as técnicas em biologia molecular permitem hoje a observação de polimorfismo diretamente na seqüência gênica de organismos. Os marcadores moleculares abriram novas perspectivas para pesquisas em conservação de espécies e biologia populacional como um todo, e têm sido largamente utilizados no monitoramento da variabilidade genética (Zucchi, 2002).

Os primeiros marcadores moleculares foram desenvolvidos na década de 60, com a introdução da técnica de eletroforese de isoenzimas. Esta técnica é baseada na detecção de polimorfismo na carga elétrica de proteínas com função enzimática, gerado por mutações na seqüência gênica (Zucchi, 2002), sendo uma forma indireta de detectar polimorfismo em seqüências de DNA. Técnicas que permitem detectar o polimorfismo diretamente em moléculas de DNA surgiram mais recentemente. $\mathrm{O}$ advento que permitiu enormes avanços nesta área foi o desenvolvimento da técnica de reação da polimerase em cadeia (PCR), na década de 80 . A possibilidade de síntese enzimática de milhões de cópias de um determinado segmento de DNA revolucionou as pesquisas em biologia molecular, e vários tipos de marcadores foram criados (Zucchi, 2002). Tais marcadores têm possibilitando o acesso à variabilidade de indivíduos em um grande número de locos (Lynch \& Milligan, 1994), gerando critérios genéticos objetivos nos quais podem ser baseadas decisões de manejo conservacionistas (Hedrick, 1999).

Dentre os diversos marcadores moleculares disponíveis atualmente, os marcadores RAPD (sigla em inglês para polimorfismo de DNA amplificado ao acaso) destacam-se pela simplicidade da técnica, entre outros fatores. A técnica, que possibilita 
a construção de mapas genéticos, o estabelecimento de relações fillogenéticas entre diferentes táxons, a obtenção de fingerprints genômicos de indivíduos, é também uma ferramenta poderosa para a análise da diversidade genética molecular em populações naturais, populações de melhoramento e bancos de germoplasma (Ferreira e Grattapaglia, 1998), sendo largamente empregada para a caracterização de populações de plantas (Huff et al., 1993).

A técnica consiste na aplicação da PCR em amostras de DNA nuclear, usando como iniciadores (primers) oligonucleotídeos construídos ao acaso (Lynch \& Milligan, 1994). Após a PCR, as milhares de cópias das regiões do genoma flanqueadas pelo primer sofrem uma eletroforese em gel de agarose. Normalmente, cada primer dirige a síntese de vários segmentos de DNA simultaneamente em diversos pontos do genoma, resultando assim em várias bandas no gel. O polimorfismo é detectado através da visualização (presença) de uma determinada banda em uma amostra e da sua ausência em outra amostra (Ferreira e Grattapaglia, 1998).

O fato de os primers para RAPD serem construídos ao acaso é o que torna a técnica simples e aplicável a qualquer organismo. Como não é necessário o conhecimento da seqüência alvo no DNA, a técnica é ideal para gerar informações a respeito da estrutura genética de populações de espécies nunca estudadas (Brown, 1999), além de proporcionar economia de tempo e recursos financeiros (Huff et al., 1993, James \& Ashburner, 1997, Ran et al., 2001). No caso de espécies raras ou ameaçadas de extinção, a técnica de RAPD mostra-se uma ferramenta de grande valia, gerando, em pouco tempo, a partir de nenhum conhecimento prévio sobre o organismo, informações importantes, ao menos preliminares para outros estudos mais detalhados. Brown (1999), destaca esta particularidade da técnica em seu trabalho. Sua tese teve como objetivo verificar o potencial da análise RAPD para acessar a variabilidade genética de espécies raras de Proteaceae da região do Cabo, África, e verificar o uso de tal informação para o manejo conservacionista destas plantas.

Ainda no caso de espécies raras ou ameaçadas, nas quais o material biológico é escasso, RAPD é considerada a técnica ideal por utilizar quantidades mínimas de tecido (Caetano-Anollés et al., 1991; James \& Ashburner, 1997; Palácios \& 
Gonzáles-Candelas, 1997). Segundo Brown (1999), esta característica é de particular interesse no caso de plantas mais susceptíveis à infecção por fungos após ferimentos (como no caso das espécies estudadas pela autora), onde o dano causado pela coleta deve ser o menor possível.

Em relação a outras classes de marcadores, os marcadores RAPD possibilitam uma amostragem aleatória mais ampla do genoma (Lynch \& Milligan, 1994), sendo eficientes, portanto, para estudos de divergência genética nos quais os indivíduos analisados são geneticamente próximos (Wadt, 2001). Esta particularidade é de especial interesse para o estudo de espécies raras, com populações pequenas, e, principalmente, que apresentam reprodução assexuada como principal forma de propagação (Palácios \& Gonzáles-Candelas, 1997). Em espécies com estas características, é esperado um baixo grau de variabilidade genética, sendo RAPD o marcador ideal devido à sua habilidade em detectar baixos níveis de polimorfismo (Rossetto et al., 1999). Marcadores RAPD são eficientes em detectar variabilidade dentro de populações mesmo quando esta não pode ser detectada por isoenzimas (Bauert et al., 1998; Brown, 1999). A respeito deste tópico, uma boa discussão pode ser encontrada no trabalho de Vandewoestijne \& Baguette (2002), que estudaram populações fragmentadas de borboletas Boloria aquilonaris na Europa, através de marcadores RAPD e isoenzimas.

A maior limitação da técnica de RAPD é o fato de não ser possível discriminar genótipos heterozigóticos de genótipos homozigóticos dominantes. Por isso RAPD é denominado como "marcador dominante", e, assim, menos informativo que marcadores codominantes (Ferreira \& Grattapaglia, 1998). Como conseqüência da característica dominante, não é possível estimar a freqüência de um alelo particular em uma população, isto é, a frequiência alélica ou gênica. Porém, a estrutura genética de populações tem sido tradicionalmente estudada através dos desvios na freqüência alélica em relação ao esperado para populações panmíticas (Excoffier et al., 1992), isto é, para populações em Equilíbrio de Hardy-Weinberg. O número de alelos por loco, a heterozigosidade observada e a heterozigosidade esperada têm sido os parâmetros genéticos mais utilizados para quantificar a variabilidade genética em populações de 
plantas. Assim, as três principais abordagens para a caracterização da estrutura genética de populações, isto é, as estatísticas F de Wright (1965), a análise da diversidade gênica em populações subdivididas (Nei, 1977) e os coeficientes de coancestralidade de Cockerham (Cockerham, 1969, Weir,1996,Vencovsky, 1992), só podem ser realizadas através do uso de marcadores codominantes (Zucchi, 2002).

Apesar de sua limitação, a técnica de RAPD tem sido utilizada com sucesso para a análise da diversidade genética molecular em populações naturais de plantas, como nos trabalhos de Buso et al. (1998), Gauer \& Cavalli-Molina (2000), Ge et al. (1999), Huff et al. (1993), Keller (2000), Koppitz (1999), Lacerda et al. (2001), Reis (1999), Wadt (2001) e Zucchi (2002), entre muitos outros. A utilização de marcadores RAPD para a geração de informações úteis para programas de conservação de espécies ameaçadas pode ser verificada nos trabalhos de Ayres \& Ryan (1999), Bauert et al. (1998), Bekessy et al. (2002), Brown (1999), Bucci et al. (1997), Esselman et al. (1999), Fischer et al. (2000), Gillies et al. (1999), Hsu et al. (2000), Jimenez et al. (2002), Martin \& Bermejo (2000), Palácios \& Gonzalez-Cándelas (1997), Persson \& Gustavsson (2001), Rossetto et al. (1999), Sydes \& Peakall (1998), Tansley \& Brown (2000), entre outros.

James \& Ashburner (1997), por exemplo, ao estudarem a estrutura genética de populações da Liliaceae Astelia australiana, deixam claro que a variabilidade genética foi subestimada, devido à natureza do marcador. Afirmam porém que a técnica de RAPD forneceu informação suficiente para o desenvolvimento de estratégias de conservação da planta em estudo.

Zucchi (2002), analisou a estrutura genética de populações de Eugenia dysenterica, a cagaita, utilizando marcadores RAPD, e comparou os resultados com aqueles obtidos por SSR, um marcador codominante. A autora observou que houve congruência entre os parâmetros populacionais obtidos com os dois tipos de marcadores, embora algumas discrepâncias também tenham sido observadas, como na estimativa do fluxo gênico. Sua conclusão foi que a metodologia de análise da estrutura genética através do uso do marcador dominante RAPD é viável e congruente com dados obtidos através do uso de marcadores codominantes (SSR) e isoenzimáticos, e que, apesar de 
possuírem diferentes naturezas, todos são igualmente informativos para estudos populacionais. Muitos outros trabalhos realizaram a comparação entre RAPD e algum marcador codominante, obtendo resultados similares a partir dos dados gerados pelas duas classes de marcadores, tais como os trabalhos de Aagaard et al. (1998) e de Buso et al., (1998).

Há algumas maneiras de se contornar a limitação dos marcadores RAPD. A primeira delas é assumir que a população está em equilíbrio de Hardy-Weinberg, e, considerando as ausências de bandas como homólogas, podem-se estimar as freqüências alélicas (Buso et al., 1998, Fischer et al., 2000, Lynch \& Milligan, 1994). Alguns exemplos de utilização desta abordagem podem ser encontrados nos trabalhos de Pither et al. (2003) e Vandewoestijne \& Baguette (2003), entre outros. No caso de populações pequenas, ou de espécies com reprodução assexuada, por exemplo, assumir equilíbrio de Hardy-Weinberg pode ser muito artificial, e esta abordagem deve ser evitada (Palácios \& González-Candelas, 1997). Outra estratégia é a utilização dos estimadores nãotendenciosos para frequiências alélicas propostos por Lynch \& Milligan (1994). Uma terceira alternativa é o estudo de duas ou mais gerações, onde é possível, através da progênie, conhecer o genótipo dos parentais e estimar frequiências alélicas. Tal abordagem foi utilizada por Wadt (2001), entre outros. Por fim, conforme Buso et al., (1998), uma alternativa para o uso de dados gerados via RAPD seria a utilização da Análise de Variância Molecular (AMOVA, Excoffier et al. 1992). Segundo Zucchi, (2002), que utilizou a AMOVA, a frequência alélica não foi essencial para que a distribuição da diversidade genética molecular fosse compreendida.

Para a mensuração da diversidade genética total de uma espécie ou população, podem ser adotadas abordagens que são indiferentes à característica dominante dos marcadores RAPD. Ge et al. (1999), por exemplo, estudaram populações naturais do arroz selvagem Oryza rufipogon na China e no Brasil, através da técnic a molecular de RAPD. A diversidade genética das populações foi mensurada através da porcentagem de bandas polimórficas ( $\mathrm{PPB}$, percentage of polymorphic bands), calculada através do número de bandas polimórficas em relação ao número total de bandas produzidas. Os resultados indicaram que as populações da China apresentam maior 
diversidade genética molecular $(\mathrm{PPB}=55,8)$ do que as populações do Brasil $(\mathrm{PPB}=41,1)$. Obviamente, tal comparação exige que as populações, espécies, etc, sejam estudadas com os mesmos primers, nas mesmas condições de amplificação. Outra estratégia para a mensuração da diversidade genética molecular de uma dada espécie ou população é a utilização do Índice de Diversidade de Shannon-Wiener (Shannon, 1948), que é dado pela expressão $H=-\Sigma P i \cdot \log _{2} P i$, sendo Pi a frequiência de uma dada banda. Este índice é adequado para a análise de dados RAPD devido à sua insensibilidade ao viés causado pela dominância do marcador (Maki \& Horie, 1999, Sun \& Wong, 2001), e pode ser

utilizado tanto para comparar a diversidade entre espécies como entre populações da mesma espécie. Sun \& Wong (2001), por exemplo, utilizaram este índice para comparar a diversidade genética molecular encontrada em três espécies de orquídeas. Jimenez et al. (2002), utilizaram o índice para comparar a diversidade genética molecular existente em quatro populações de Antirrhinum subbaeticum. Outros exemplos da utilização do Índice de Diversidade de Shannon-Wiener para a mensuração da diversidade genética molecular detectada por marcadores RAPD podem ser encontrados nos trabalhos de Bekessy et al. (2002), Chalmers et al. (1992), Gauer \& Cavalli-Molina (2000), Lacerda et al. (2001), Pither et al. (2003), e entre muitos outros. Este índice é muitas vezes inadequadamente chamado de "índice de diversidade de Shannon-Weaver" ou "indice de diversidade de Shannon" (Spellerberg \& Fedor, 2003).

\subsection{Análise de variância molecular (AMOVA)}

Excoffier et al (1992), pela introdução das estatísticas $\Phi$, proporcionaram uma nova alternativa para o uso de narcadores dominantes, utilizada em populações naturais de plantas pela primeira vez por Huff et al., em 1993. Após o trabalho de Huff et al., muitos autores utilizaram a AMOVA para descrever a estrutura genética de populações de plantas, como Brown (1999), Buso et al. (1998), Fischer et al. (2000), Ge et al. (1999), Gillies et al. (1999), Jimenez et al. (2002), Lacerda et al. (2001), Maki \& Horie (1999), Martin \& Bermejo (2000), Palácios \& Gonzáles-Candelas (1997), Person 
\& Gustavsson (2001), Pither et al. (2003), Reis (1999), Tansley \& Brown (2000), Wadt (2001) e Zucchi (2002), entre outros.

Tal abordagem dispensa o conhecimento das freqüências alélicas ou assunções específicas (Excoffier et al., 1992). Informações sobre a divergência de DNA de dados provenientes de haplótipos são incorporadas a uma análise no formato de análise de variância, derivada da matriz de quadrados das distâncias entre todos os pares de haplótipos. Esta análise de variância, denominada AMOVA, produz estimativas dos componentes de variância análogas às estatísticas $\mathrm{F}$ de Wright, denominadas pelos autores de estatísticas $\Phi$. As estatísticas $\Phi$ refletem a correlação da diversidade haplotípica em diferentes níveis de subdivisão hierárquica. Para o desenvolvimento da AMOVA os autores basearam se 1 . na idéia de que quando uma espécie exibe subdivisão em demes, espera-se um aumento da diversidade haplotípica e um aumento do polimorfismo entre genomas amostrados em diferentes demes, colocada por Slatkin, (1987) e 2. na idéia de que a Soma de Quadrados pode ser escrita na forma de quadrados de diferenças entre todos os pares de observação, proposta por Li (1976). A partir destas proposições os autores desenvolveram uma análise hierárquica da variância molecular diretamente a partir da matriz de soma de quadrados de diferenças entre haplótipos. Isso permite que os indivíduos sejam agrupados em vários níveis, de acordo com critérios não genéticos (geografia, habitat, população, etc), definidos a priori. Os diferentes níveis hierárquicos possuem componentes de variância $\left(\sigma^{2}\right)$ associados, extraídos a partir dos quadrados médios (QMs) em relação ao esperado. Esta estrutura é análoga àquela descrita para as estatísticas F, desenvolvida por Cockerham, (1969, 1973), segundo os autores.

Seguindo o esquema de Cockerham, assumindo três níveis hierárquicos ( $a=$ regiões, $b=$ populações dentro de regiões e $c=$ indivíduos dentro de populações), para as estatísticas $\Phi$ teremos que:

$$
\begin{aligned}
& \sigma^{2} \mathrm{c}=\left(1-\Phi_{\mathrm{st}}\right) \sigma^{2} \\
& \sigma^{2} \mathrm{~b}=\left(\Phi_{\mathrm{st}}-\Phi_{\mathrm{ct}}\right) \sigma^{2}, \\
& \sigma^{2} \mathrm{a}=\Phi_{\mathrm{ct}} \sigma^{2},
\end{aligned}
$$




$$
\text { sendo } \sigma^{2}=\sigma^{2} a+\sigma^{2} b+\sigma^{2} c
$$

e

$$
\Phi_{\mathrm{st}}=\text { correlação entre haplótipos aleatórios dentro de populações em }
$$
relação à correlação entre pares de haplótipos aleatórios amostrados da espécie como um todo;

$$
\Phi_{\mathrm{ct}}=\text { correlação entre haplótipos aleatórios dentro de regiões em relação à }
$$
correlação entre pares de haplótipos aleatórios amostrados da espécie como um todo;

$$
\Phi_{\mathrm{sc}}=\text { correlação da diversidade molecular de haplótipos aleatórios dentro }
$$

de populações em relação à correlação entre pares de haplótipos aleatórios retirados da região.

As equações podem então ser reescritas na forma de estatísticas $\Phi$ :

$$
\begin{aligned}
& \Phi_{\mathrm{st}}=\sigma^{2} \mathrm{a}+\sigma^{2} \mathrm{~b} / \sigma^{2} \\
& \Phi_{\mathrm{ct}}=\sigma^{2} \mathrm{a} / \sigma^{2} \\
& \Phi_{\mathrm{sc}}=\sigma^{2} \mathrm{~b} / \sigma^{2} \mathrm{~b}+\sigma^{2} \mathrm{c}
\end{aligned}
$$

De acordo com Excoffier et al. (1992), a AMOVA deve ser entendida como uma sumarização da distribuição da informação genética em níveis hierárquicos. Apesar de não originalmente desenvolvida para a análise de dados gerados por RAPD, a AMOVA tem se mostrado eficiente, com habilidade para testar a significância estatística de dados hierárquicos não demonstrada até então por outros tipos de análise, segundo Tansley \& Brown (2000). A AMOVA constitui uma estrutura coerente e flexível para a análise de dados moleculares. 


\section{MATERIAIS E MÉTODOS}

\subsection{Observações de campo}

Foi realizada uma expedição ao habitat natural das espécies contempladas na pesquisa, conduzida pela Dra. Rafaela Forzza (Instituto de Pesquisas Jardim Botânico do Rio de Janeiro), especialista no gênero Encholirium. O objetivo desta expedição foi a observação de fatores que podem afetar a estrutura genética das populações, bem como de particularidades que podem vir a ser relevantes para a conservação destas espécies.

Os seguintes fatores foram observados:

- hábito (formação de touceiras, indivíduos isolados);

- presença de plântulas;

- número aproximado de indivíduos;

- distribuição espacial dos indivíduos;

- presença de flores ou frutos;

- antropização da paisagem, distúrbios e ameaças às populações. 


\subsection{Amostragem do material}

\subsubsection{Critérios gerais de amostragem}

As espécies contempladas neste trabalho são todas de hábito clonal, distribuindo-se em densas touceiras com várias rosetas. Desta forma, todas as rosetas (ou rametos) pertencentes à mesma touceira são geneticamente idênticas (compõem um geneto). Em trabalhos de ecologia, por exemplo, um rameto pode ser considerado um indivíduo, por ter desenvolvimento e fenologia independentes das demais rosetas da mesma touceira, realizando funções ecológicas de indivíduo. Neste trabalho, porém, trataremos por indivíduo todo o conjunto de rosetas interligadas, uma vez que são geneticamente idênticas (a menos que ocorram mutações somáticas, queassumiremos insignificantes neste contexto). Não faria sentido, portanto, amostrar mais do que uma roseta por touceira, já que isso significaria amostrar mais de uma vez o mesmo indivíduo. A coleta foi cuidadosa, portanto, no sentido de não amostrar indivíduos pertencentes à mesma touceira. De acordo com este critério, foram amostrados aproximadamente $50 \%$ dos indivíduos presentes nas populações, através da coleta de uma ou mais folhas de cada touceira ou planta isolada. As Figuras 1 e 2 (apresentadas nos ítens 2.1.1 e 2.2.2), mostram touceiras de E. biflorum e E. pedicellatum. Tais touceiras foram consideradas indivíduos, de modo que apenas uma amostra de cada touceira foi coletada.

Deve-se considerar a hipótese de que uma touceira, por motivos diversos, pode vir a ser separada em duas. Assim, indivíduos que ocorrem próximos uns dos outros (distância de alguns centímetros), mesmo sem ligação física, podem ser clones. Caso isso ocorra, será detectado pela análise de RAPD, uma vez que ambos foram amostrados.

Portanto, quando nos referimos à estrutura clonal neste trabalho, consideramo-la em dois níveis: o nível das rosetas ainda ligadas fisiologicamente, que é óbvio a partir de simples inspeção no campo; e o nível dos indivíduos clonados mas 
fisiologicamente já independentes, que é impossível de ser constatado diretamente no campo. A amostragem foi planejada, pois, de modo a estudar este segundo nível.

\subsubsection{Amostragem de $E$. biflorum}

Foi amostrada a única população conhecida desta espécie. A população está situada em propriedade particular próxima à estrada Diamantina-Biribiri, no Planalto de Diamantina (ver mapa adiante, Figura 11). As plantas estão distribuídas em três agrupamentos, sendo que a distância média entre agrupamentos é de 11,3 m (Tabela 1; Figura 5). Foram amostrados indivíduos de cada um dos três agrupamentos. No total, 31 indivíduos foram amostrados (média de 10,33 indivíduos por agrupamento), sendo que o número máximo de indivíduos nesta população está próximo de 60 .

Tabela 1. Distâncias entre agrupamentos e tamanho amostral (n) dos agrupamentos de Encholirium biflorum

\begin{tabular}{cccccc}
\hline Agrupamentos & $\mathrm{n}$ & 1 & 2 & 3 & Média \\
\hline 1 & 14 & - & & & \\
2 & 13 & $15 \mathrm{~m}$ & - & & \\
3 & 04 & $17 \mathrm{~m}$ & $2 \mathrm{~m}$ & - & $11,33 \mathrm{~m} *$ \\
Total & 31 & & & & $10,33 * *$ \\
\hline
\end{tabular}

* Distância média entre os agrupamentos

** Número médio de indivíduos amostrados por agrupamento 


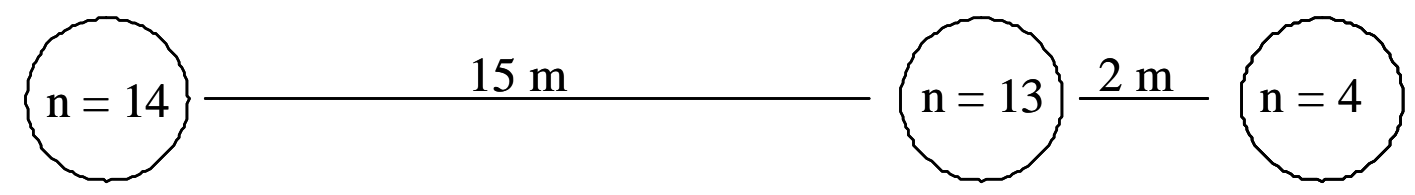

Figura 5 - Esquema da distribuição espacial dos agrupamentos de Encholirium biflorum, mostrando também o número de indivíduos amostrados em cada agrupamento (n)

\subsubsection{Amostragem de E. pedicellatum}

Foi amostrada a única população de $E$. pedicellatum conhecida, localizada em propriedade particular à beira da estrada que liga Diamantina a Biribiri (ver mapa adiante, Figura 11) Observou-se a distribuição das plantas em seis agrupamentos, sendo amostrados cinco deles. Os agrupamentos estão distribuídos ao longo de um afloramento rochoso, sendo a menor distância entre agrupamentos igual a 5 $\mathrm{m}$, e a maior, aproximadamente $155 \mathrm{~m}$ (Tabela 2; figura 6). Dentro de cada agrupamento foram observadas em torno de 15 touceiras ou indivíduos solitários, sendo amostrados em média, 6,2 indivíduos por agrupamento (aproximadamente metade da população).

Tabela 2. Distâncias entre agrupamentos e tamanho amostral (n) dos agrupamentos de Encholirium pedicellatum

\begin{tabular}{cccccccc}
\hline Agrupamento & $\mathrm{N}$ & 1 & 2 & 3 & 4 & 5 & Média \\
\hline 1 & 4 & - & & & & & \\
2 & 7 & $20 \mathrm{~m}$ & - & & & & \\
3 & 6 & $20 \mathrm{~m}$ & $100 \mathrm{~m}$ & - & & & \\
4 & 7 & $150 \mathrm{~m}$ & $130 \mathrm{~m}$ & $30 \mathrm{~m}$ & - & & $88 \mathrm{~m}^{*}$ \\
5 & 7 & $155 \mathrm{~m}$ & $135 \mathrm{~m}$ & $35 \mathrm{~m}$ & $5 \mathrm{~m}$ & - & $6,2 * *$ \\
\hline
\end{tabular}

* Distância média entre os agrupamentos

** Número médio de indivíduos amostrados por agrupamento 


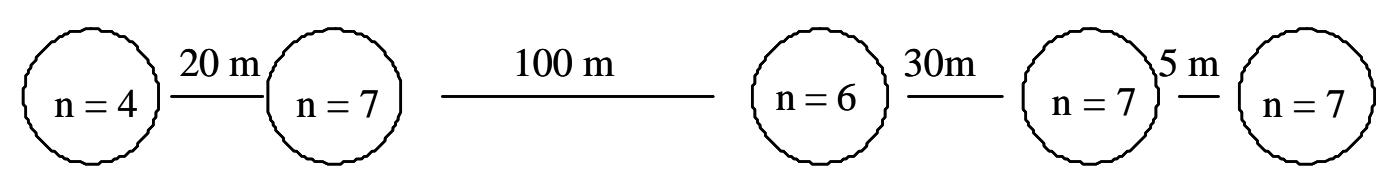

Figura 6 - Esquema da distribuição espacial dos agrupamentos de Encholirium pedicellatum, mostrando também o número de indivíduos amostrados em cada agrupamento (n)

\subsubsection{Amostragem de E. subsecundum}

Foram amostradas quatro populações no Planalto de Diamantina (ver mapa adiante, Figura 11). Certamente muitas outras populações existentes na região não foram amostradas, uma vez que foram coletadas apenas as populações mais próximas da pista. As distâncias entre as populações amostradas foram em média de 116,66 km (Tabela 3; Figura 7).

Tabela 3. Distâncias geográficas entre populações e tamanho amostral (n) das populações de Encholirium subsecundum

\begin{tabular}{ccccccc}
\hline População & $\mathrm{N}$ & 1 & 2 & 3 & 4 & Média \\
\hline 1 & 23 & - & & & & \\
2 & 25 & $50 \mathrm{~km}$ & - & & & \\
3 & 18 & $150 \mathrm{~km}$ & $100 \mathrm{~km}$ & - & & $116,66 \mathrm{~km}^{*}$ \\
4 & 11 & $200 \mathrm{~km}$ & $150 \mathrm{~km}$ & $50 \mathrm{~km}$ & & $19,25^{* *}$ \\
Total & 77 & & & & & 19.96 \\
\hline
\end{tabular}

* Distância média entre as populações

** Número médio de indivíduos amostrados por agrupamento 


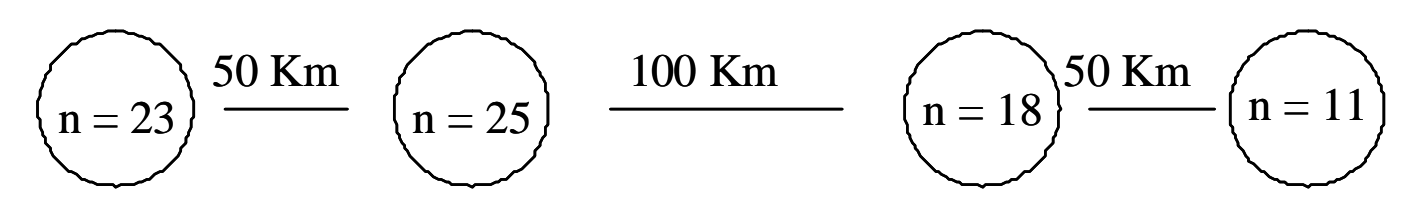

Figura 7 - Esquema da distribuição espacial das populações de Encholirium pedicellatum, mostrando também o número de indivíduos amostrados em cada população (n)

A primeira população foi coletada ao longo da estrada Diamantina-Milho Verde. No total, quatro agrupamentos de plantas foram encontrados ao longo de aproximadamente $6 \mathrm{~km}$, sendo todos amostrados. Cada agrupamento era formado por apenas poucas plantas (no máximo 10), próximas entre si, com distâncias máximas de 5 m. Foram amostrados em média 5,75 indivíduos por agrupamento. As distâncias entre agrupamentos variaram de $800 \mathrm{~m}$ a $5.800 \mathrm{~m}$, sendo a distância média entre agrupamentos igual a 3.066,66 m (Tabela 4; Figura 8).

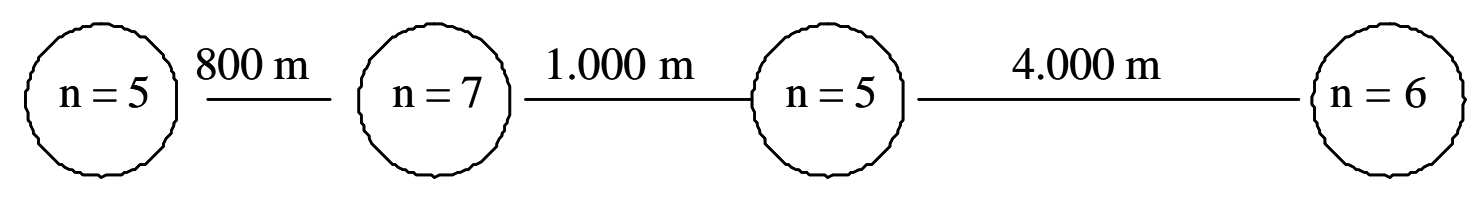

Figura 8 - Esquema da distribuição espacial dos agrupamentos da População 1 de Encholirium subsecundum, mostrando também o número de indivíduos amostrados em cada agrupamento (n)

A segunda população foi encontrada sobre um afloramento rochoso plano, entre as cidades de Milho Verde e Serro, de aproximadamente $1.000 \mathrm{~m}^{2}$. O número de indivíduos nesta população foi estimado em 150, sendo amostrados 25 deles. A distribuição das touceiras era uniforme sobre o afloramento, de modo que não havia 
agrupamentos naturais de indivíduos separados de outros agrupamentos. Por este motivo, a população foi amostrada sem subdivisão em agrupamentos.

A terceira população foi encontrada na beira da estrada MG-010, próxima da ponte sobre o Rio Santo Antônio. Havia afloramentos dos dois lados da pista, onde vegetavam as plantas. De um lado da pista foram amostrados dois agrupamentos de 6 indivíduos cada, e do outro lado, outro agrupamento de 6 indivíduos. Muitos indivíduos não puderam ser coletados devido à dificuldade de acesso, mas aproximadamente metade da população foi amostrada (Tabela 4; figura 9).

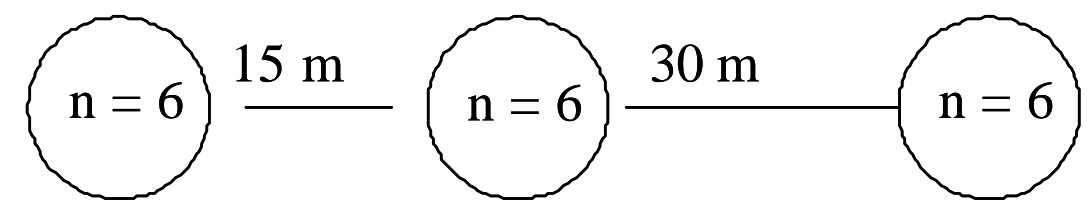

Figura 9 - Esquema da distribuição espacial dos agrupamentos da População 3 de Encholirium subsecundum, mostrando também o número de indivíduos amostrados em cada agrupamento (n)

A quarta população está dentro da Área de Proteção Ambiental da Serra do Cipó. Foram encontrados três agrupamentos de plantas desta espécie. Dois agrupamentos estavam sobre um afloramento rochoso, e o terceiro estava sobre o aforamento vizinho, distando aproximadamente $5 \mathrm{~m}$ um do outro. Os agrupamentos eram muito pequenos, compostos por aproximadamente 7 indivíduos. Foram coletados, em média, 3,3 indivíduos por agrupamento (Tabela 4; Figura 10). No total, para esta espécie, 77 indivíduos foram amostrados. 


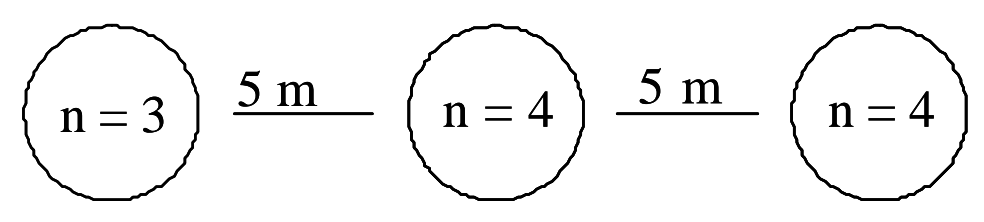

Figura 10 - Esquema da distribuição espacial dos agrupamentos da População 4 de Encholirium subsecundum, mostrando também o número de indivíduos amostrados em cada agrupamento (n)

Tabela 4. Distâncias entre agrupamentos (da mesma população) e tamanho amostral (n) dos agrupamentos de Encholirium subsecundum

\begin{tabular}{cccccccc}
\hline População & Agrupamento & $\mathrm{n}$ & 1 & 2 & 3 & 4 & Média \\
\hline 1 & 1 & 5 & - & & & \\
& 2 & 7 & $800 \mathrm{~m}$ & - & & \\
& 3 & 5 & $1.800 \mathrm{~m}$ & $1.000 \mathrm{~m}$ & - & \\
& 4 & 6 & $5.800 \mathrm{~m}$ & $5.000 \mathrm{~m}$ & $4.000 \mathrm{~m}$ & - & $3.066,66 \mathrm{~m} *$ \\
3 & 1 & 6 & - & & & $5,75 * *$ \\
& 2 & 6 & $15 \mathrm{~m}$ & - & & $30 \mathrm{~m}^{*}$ \\
& 3 & 6 & $45 \mathrm{~m}$ & $30 \mathrm{~m}$ & - & $6,0 * *$ \\
4 & 1 & 3 & - & & & \\
& 2 & 4 & $5 \mathrm{~m}$ & - & & $3,16 \mathrm{~m} *$ \\
& 3 & 4 & $5 \mathrm{~m}$ & $2,5 \mathrm{~m}$ & - & \\
\hline
\end{tabular}

* Distância média entre os agrupamentos da mesma população

** Número médio de indivíduos amostrados por agrupamento 


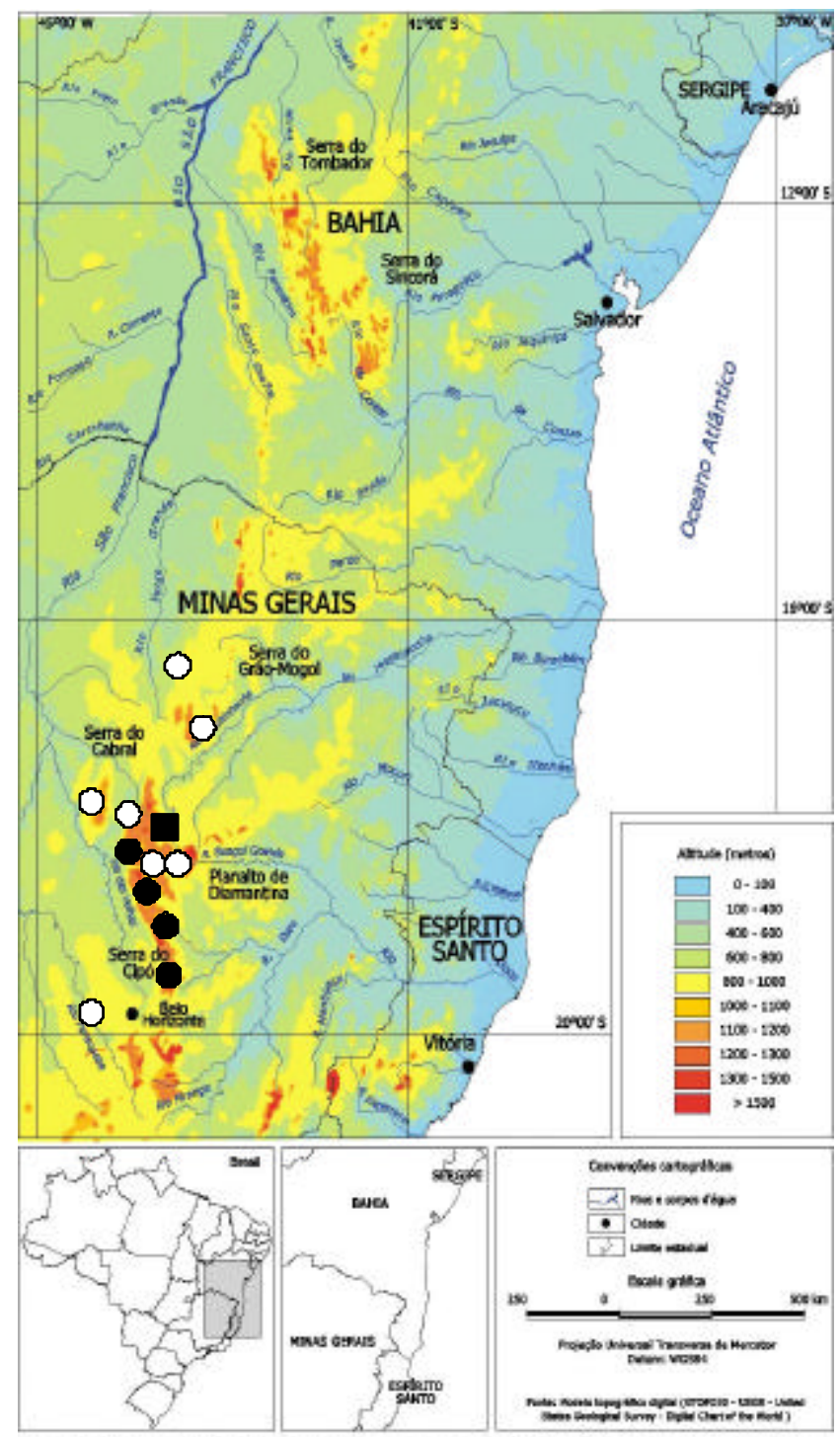

Figura 11 - Mapa físico da região de ocorrência das espécies (Cadeia do Espinhaço, em amarelo). O quadrado preto no mapa representa o local de coleta de $E$. biflorum e E. pedicellatum. Os círculos pretos representam os locais de coleta de E. subsecundum. Os círculos brancos representam outras localidades onde ocorre E. subsecundum 


\subsubsection{Armazenamento e transporte das amostras}

Todas as amostras foram compostas por uma ou poucas folhas jovens de cada indivíduo, retiradas com o auxílio de um estilete. As amostras foram imediatamente colocadas em envelope de papel pardo devidamente identificado, acondicionado em embalagem plástica contendo sílica-gel. Ao final de cada dia a sílica-gel era substituída por outra mais nova, a fim de absorver ao máximo a umidade. Ao chegarem no laboratório, as amostras foram congeladas até o momento do uso.

\subsection{Análise de RAPD}

\subsubsection{Extração de DNA}

A extração de DNA foi realizada de acordo com Ferreira e Grattapaglia (1995), com modificações. A partir de cada amostra pesaram-se $100 \mathrm{mg}$ de tecido foliar, o qual foi picado com o auxílio de bisturi e pinça sobre placa de Petri. O material foi então transferido para um almofariz, onde recebeu $\mathrm{N}_{2}$ líquido, sendo imediatamente congelado e macerado, processo no qual ocorre o rompimento das paredes e membranas celulares do tecido. Após a maceração, cada amostra foi transferida para um microtubo de 1,5 ml (Axygen Scientific, modelo MCT-150-C), devidamente identificado, sendo imediatamente congelada a $-20^{\circ} \mathrm{C}$. Em banho-maria (Dubnoff MA 093, Marconi), aqueceurse a $65^{\circ} \mathrm{C}$ um tampão de extração composto de $10 \%$ (v/v) de solução Tris- $\mathrm{HCl}$ $1 \mathrm{M} \mathrm{pH} \mathrm{8.0,2 \%} \mathrm{(p/v)} \mathrm{de} \mathrm{CTAB} \mathrm{(cationic} \mathrm{hexadecyl} \mathrm{trimethylammonium} \mathrm{bromide),} \mathrm{4 \%}$ (v/v) de EDTA (ethylenediaminetetracetate) 0,5 M pH 8.0, 8,18\% (p/v) de $\mathrm{NaCl}, 1 \%$ (p/v) de PVP 40.000 polyvinylpyrrolidone). Ao tampão aquecido acrescentou-se 5\% (v/v) de 2- $\beta$-mercaptoetanol. Cada amostra recebeu então $900 \mu \mathrm{L}$ deste tampão, sendo imediatamente agitada em vórtice (Vortex-Genie K-550-G, Scientific Industries Inc.) e colocada em banho-maria $65^{\circ} \mathrm{C}$ por uma hora, sendo agitadas manualmente por inversão 50 vezes a cada 10 minutos. Durante este processo ocorre a solubilização das membranas celulares. Transcorrido o tempo de incubação, esperou-se que as amostras 
atingissem a temperatura ambiente, para então receberem $60 \%$ (v/v) de clorofórmioálcool isoamílico na proporção de 24 partes de clorofórmio para uma parte de álcool isoamílico (CIA 24:1). Então agitaram-se manualmente as amostras durante 5 minutos. Em seguida, as amostras foram centrifugadas por 5 minutos a $14.000 \mathrm{rpm}$ (Microfuge E, Bekman), separando-se as fases orgânica (superior) e aquosa (inferior). Quatrocentos microlitros do sobrenadante (fase orgânica), foram transferidos para novo tubo identificado. As amostras sofreram outro ciclo de emulsificação com $500 \mu$ l CIA 24:1 e centrifugação, e novamente o sobrenadante foi transferido para novo tubo (400 $\mu 1)$. O DNA+RNA foi então precipitado com $60 \%$ do volume de isopropanol $-20^{\circ} \mathrm{C}$ por aproximadamente 15 horas em congelador. Passado o período de precipitação, as amostras foram centrifugadas por 20 minutos a $14.000 \mathrm{rpm}$. Após esta etapa, formou-se um pellet visível, composto basicamente de DNA e RNA. O sobrenadante foi descartado e o pellet lavado com $1 \mathrm{ml}$ de etanol a $70 \%$ (v/v) por 5 minutos duas vezes, e depois lavado com $1 \mathrm{ml}$ de etanol a 95\% (v/v) por 3 minutos. Após a lavagem, as amostras foram secadas ao ar até a completa evaporação do etanol e ressuspendidas em $75 \mu 1$ de solução Tris-EDTA (1\% v/v Tris-HCl 1 M pH 8.0 e 0,2\% v/v de EDTA 0,5 M pH 8.0 em água destilada autoclavada). A seguir as amostras receberam $20 \mathrm{mg}$ de RNAse (Ribonuclease A Bovine Pancreas, USBiological). A RNAse foi fornecida através de solução composta de $1 \%(\mathrm{p} / \mathrm{v})$ de RNAse, $1 \%$ (v/v) de Tris-HCl $1 \mathrm{M}$ pH 7.5 e 1,5\% (v/v) de $\mathrm{NaCl} 1 \mathrm{M}$ em água deionizada autoclavada. Esta solução foi previamente fervida em banho-maria em um bécker sobre bico de Bunsen por 15 minutos, e depois, resfriada a temperatura ambiente. O RNA das amostras foi degradado durante incubação em banho-maria a $37^{\circ} \mathrm{C}$ por uma hora, sendo as amostras então armazenadas a temperatura de $-20^{\circ} \mathrm{C}$. 


\subsubsection{Quantificação e padronização das amostras de DNA}

A quantificação da concentração de DNA existente em cada amostra foi realizada por análise comparativa em géis de agarose corados com brometo de etídeo. $\mathrm{O}$ tamanho e intensidade das bandas produzidas pelas amostras de DNA dos indivíduos foram comparados com o tamanho e intensidade das bandas produzidas por amostras de concentração conhecida.

Foram feitos géis de agarose (Labtrade do Brasil) a 0,8\% (p/v) em solução TBE 1X. A solução TBE $1 X$ foi feita a partir da diluição de uma parte de solução TBE 10X em nove partes de água destilada. A solução TBE 10X foi composta de 10,8\% (p/v) de Tris Base, 5,5\% (p/v) de Ácido Bórico e 4,0\% (v/v) de solução EDTA 0,5 M pH 8.0 em água destilada autoclavada. A agarose foi colocada em enlenmeyer de $500 \mathrm{ml}$, juntamente com o volume de TBE 1X, e fervida em forno de microondas até sua completa dissolução. Em seguida, adicionourse 0,1\% (v/v) de brometo de etídeo (Life Technologies do Brasil) a uma concentração de $10 \mathrm{mg} / \mathrm{ml}$, e agitou-se bem, para então verter o gel na forma e aguardar sua completa polimerização. O gel polimerizado foi colocado então na cuba de eletroforese, na qual foi então vertida solução TBE 1X até que o gel ficasse totalmente submerso.

Os cinco primeiros poços do gel receberam concentrações conhecidas de DNA. Para tal, foram preparadas amostras de diferentes concentrações a partir de diferentes volumes de DNA Lambda (GibcoBRL, Life Technologies) em solução de $15,25 \%$ (v/v) de tampão de carregamento em água deionizada autoclavada. O tampão de carregamento foi feito com $40 \%(\mathrm{p} / \mathrm{v})$ de sacarose, $0,1 \%(\mathrm{p} / \mathrm{v})$ de azul de bromofenol em solução Tris-EDTA pH 8.0. Foram produzidas amostras de 10, 20 e 50 ng de DNA/ $\mu 1$. Estas amostras foram utilizadas para carregar os poços do gel com as concentrações desejadas. Desta forma, no primeiro poço colocaram-se $2 \mu \mathrm{l}$ da amostra de $10 \mathrm{ng}$ de DNA/ $\mu 1$, obtendo-se um poço com 20 ng. O mesmo procedimento foi seguido para se obterem poços com 40, 60, 100 e 200 ng de DNA.

Os demais poços do gel foram preenchidos com as amostras de DNA extraídas das plantas. Foram adicionados a cada poço $3 \mu \mathrm{l}$ da amostra, sem diluição 
prévia, e $3 \mu \mathrm{l}$ de tampão de carregamento. As amostras sofreram eletroforese a uma voltagem de $130 \mathrm{~V}$ por 30 minutos.

Decorrido o tempo de eletroforese, o gel foi retirado da cuba e levado para o aparelho de fotodocumentação (BioRad Gel Doc 1000). O gel foi fotografado sobre fonte de luz ultravioleta, revelando as bandas de DNA marcado com o brometo de etídeo.

A intensidade e tamanho das bandas produzidas pelas amostras foi comparada com a daquelas produzidas pelas amostras de concentração conhecida. Assim foi possível estimar a concentração de DNA em cada uma das amostras.

Neste mesmo gel foi possível avaliar a qualidade geral das amostras. Foi possível observar se o DNA presente estava íntegro ou degradado e se havia impurezas ou RNA. Esta avaliação, por vezes, revelou a necessidade de novas extrações para que fosse obtida uma amostra de melhor qualidade. Após a quantificação, todas as amostras foram padronizadas a $0,2 \mathrm{ng} / \mu \mathrm{l}$ em solução Tris-EDTA.

\subsubsection{Teste e seleção de primers de RAPD}

Foram testados 92 primers RAPD escolhidos de maneira aleatória nos kits OPA, OPB, OPC, OPE, OPG, OPP, OPX e OPAX, da Operon Technologies. A verificação do perfil de amplificação de cada primer foi realizada em gel de eletroforese após PCR com 3 amostras de cada uma das espécies contempladas na pesquisa.

\subsubsection{Otimização da reação de $P C R$}

Esta etapa teve por objetivo definir as concentrações ideais de cada componente da reação de PCR, além do tempo e temperatura de cada etapa da reação e do número total de ciclos, a fim de obter bandas robustas para uma leitura segura dos géis subseqüentes. Nesta etapa utilizaram-se 3 amostras de cada uma das espécies. Os

primers utilizados nesta fase foram aqueles selecionados na etapa de teste e seleção de primers RAPD (itens 3.3.3 e 4.2). 


\subsubsection{Reações de PCR}

As reações foram preparadas em microplacas para PCR (PCR-96-C, Axygen Scientific). Em cada poço da placa aliquotaram-se 5,0 $\mu 1$ da amostra de DNA (cuja concentração fora padronizada a $0,2 \mathrm{ng} / \mu \mathrm{l}$ ), de modo que a concentração final de DNA em cada reação foi de $1 \mathrm{ng}$. Às amostras de DNA foram acrescentados $20 \mu \mathrm{lde}$ um coquetel contendo 0,5 mM de DNTPs (Fermentas Life Sciences), 0,5 $\mu \mathrm{M}$ de primer (Operon Technologies), 1 unidade de Taq DNA polimerase (Fermentas Life Sciences), 6 $\mathrm{mM}$ de $\mathrm{MgCh}_{2}$ (Fermentas Life Sciences) e 10\% (v/v) de tampão (Fermentas Life Sciences) composto de $750 \mathrm{mM}$ de Tris- $\mathrm{HCl}(\mathrm{pH} 8,8)$ e $200 \mathrm{mM}$ de $\left(\mathrm{NH}_{4}\right)_{2} \mathrm{SO}_{4}$ em água deionizada autoclavada.

As reações de PCR foram feitas em termociclador Primus 96 Plus (MWG Biotech), no qual submeteram-se as amostras inicialmente a $94^{\circ} \mathrm{C}$ por 5 minutos, e, a seguir, a 55 ciclos de amplificação. Cada ciclo submeteu as amostras a $94^{\circ} \mathrm{C}$ por 1 minuto, então a $35^{\circ} \mathrm{C}$ por 1 minuto e 45 segundos e por fim a $72^{\circ} \mathrm{C}$ por 2 minutos. Após os ciclos, as amostras foram mantidas por 7 minutos a uma temperatura de $72^{\circ} \mathrm{C}$.

Os produtos da PCR foram submetidos à eletroforese em gel de agarose $1,4 \%(\mathrm{p} / \mathrm{v})$ em tampão TBE $1 \mathrm{X}$, contendo brometo de etídeo a uma concetração de $0,1 \%$ (v/v), a uma voltagem de $110 \mathrm{~V}$ por 4 horas. O Gene Ruler $100 \mathrm{bp}$ DNA Ladder Plus (Fermentas Life Sciences) foi utilizado como marcador de peso molecular. Decorrido o tempo de eletroforese, o gel foi retirado da cuba e levado para o aparelho de fotodocumentação (BioRad Gel Doc 1000). O gel foi fotografado sobre fonte de luz ultravioleta, revelando as bandas de DNA marcado com o brometo de etídeo. 


\subsection{Análise estatística dos dados}

As bandas com fraca intensidade ou coalescentes com outras bandas foram descartadas. Apenas bandas robustas e inequívocas foram avaliadas.

A partir da leitura dos géis, os indivíduos foram genotipados quanto à presença (1) e ausência (0) de bandas, gerando uma matriz binária. O programa computacional NTSYS (Rohlf, 1989), foi utilizado para gerar uma matriz de similaridades de Jaccard entre todos os pares de indivíduos com base na matriz binária. O coeficiente de Similaridade de Jaccard é dado pela expressão:

$$
S_{i j}=a / a+b+c
$$

onde $a$ é o número de casos onde ocorre a presença de banda em ambos os indivíduos simultaneamente, $b$ é o número de casos onde ocorre a presença de banda apenas no indivíduo $i$ e $c$ é o número de casos onde ocorre a presença de banda apenas no indivíduo $j$.

A partir desta matriz, o programa gerou dendrogramas baseados no método de agrupamento UPGMA (unweighted pair-group method with arithmetic averages). A estabilidade ou consistência destes agrupamentos foi testada através do procedimento de reamostragens aleatórias, com 10.000 bootstraps, através do programa Bood-P (Coelho, 2003). Os coeficientes de similaridade de Jaccard (S) obtidos nesta matriz também foram utilizados para detectar a presença de clones, sendo estes identificados através de $S_{i j}=1$. A partir da matriz de similaridades de Jaccard, foi possível calcular a dissimilaridade $(D)$ entre pares de observação, através de $D=1-S$.

Foi avaliado o número total de bandas produzidas para cada espécie, além do número de bandas polimórficas. A porcentagem de bandas polimórficas ( $P P B)$ geradas para cada espécie foi utilizada como indicadora da diversidade genética molecular. 
A diversidade genética molecular de cada espécie também foi avaliada através do índice de diversidade de Shannon-Wiener $(H)$, dado pela expressão:

$$
H=-\Sigma P i . \log _{2} P i
$$

sendo Pi a frequiência de uma dada banda. O índice foi calculado para cada loco independentemente, e posteriormente, foi calculada a média dos $H$ observados, obtendose o $H$ da espécie. O índice de diversidade de Shannon-Wiener $(H)$ também foi calculado para cada população de E. subsecundum, para que se pudesse verificar se há relação entre o tamanho da população e a variabilidade genética molecular encontrada.

A matriz binária também foi utilizada para a análise de variância molecular (AMOVA). A AMOVA foi realizada de acordo com Excoffier et al. (1992), com o auxílio do programa Arlequim (Schneider et al., 2000). Verificou-se a partição da variância genética molecular nos seguintes níveis hierárquicos: entre populações (apenas para E. subsecundum), entre agrupamentos dentro de populações e entre indivíduos dentro de agrupamentos. As distâncias genéticas foram obtidas conforme Huff et al. (1993):

$$
E=n\left[1-2 n_{x y} / 2 n\right]
$$

onde $n$ é o número total de bandas polimórficas e $2 n_{x y}$ é o número de bandas observadas nos indivíduos $x$ e $y$ simultaneamente. De acordo com Huff et al. (1993), esta equação é análoga à equação para o cálculo de distâncias genéticas entre haplótipos apresentada por Excoffier et al. (1992). 


\section{RESULTADOS E DISCUSSÃO}

\subsection{Observações de campo}

\subsubsection{Encholirium biflorum}

A população de E. biflorum amostrada está em terreno plano, de solo areno-pedregoso. O terreno, de aproximadamente um hectare, é limitado pela estrada de um lado e por afloramentos rochosos de outro. A vegetação é aparentemente homogênea neste local. A população de E. biflorum, no entanto, é formada por três agrupamentos densos, de no máximo 1,5 x 1,5 m cada e com distância média entre agrupamentos de 11,33 m. É inevitável perguntar-se por que as plantas limitam-se a poucos indivíduos concentrados numa pequena área, enquanto que, aparentemente, o terreno é uniforme e há plenas condições para o desenvolvimento de indivíduos por todo o local. Dentro de cada agrupamento, os indivíduos ou touceiras vegetam muito próximos uns dos outros (poucos centímetros). Foram observadas muitas touceiras, provavelmente formadas cada uma a partir de um único indivíduo perfilhado. Também se observaram touceiras em forma de meia-lua, dando a impressão de serem formadas por "anéis de caminhamento" de perfilhos ao longo dos anos (ver Figura 1, item 2.1.1). O hábito clonal das plantas, associado à alta densidade dos agrupamentos e ao seu tamanho diminuto, leva a crer que cada agrupamento é formado por poucos clones. Havia alguns indivíduos adultos solitários, isto é, não perfilhados e distantes de outros indivíduos. Porém, não havia nenhuma plântula solitária, indicando que o estabelecimento de plântulas na população deve ser um evento raro. Não havia nenhuma planta em floração ou frutificação nesta 
ocasião (mês de maio). A frutificação era esperada, uma vez que a floração ocorre entre outubro e janeiro.

A população é extremamente vulnerável, uma vez que está em propriedade particular. Como as plantas são diminutas e estão sobre terreno plano, correm o risco de serem facilmente destruídas por qualquer roça, criação ou benfeitoria, ou mesmo pela passagem de um trator, por exemplo.

\subsubsection{Encholirium pedicellatum}

A população de E. pedicellatum amostrada ocorre também próxima à estrada Diamantina-Biribiri. Porém, diferentemente de E. biflorum, E. pedicellatum vegeta em afloramentos rochosos, preferencialmente em fendas onde se acumulam areia e detritos. Assim, a população está distribuída por diversos "degraus" ou rochas de um mesmo afloramento. A distância média entre agrupamentos é de $88 \mathrm{~m}$. Dentro de cada agrupamento foram observadas em torno de 10 touceiras ou indivíduos solitários. A densidade é menor do que a observada em E. biflorum, e não causa a impressão de que todas as touceiras são clones. Observou-se que não há indivíduos ou touceiras isolados em relação aos agrupamentos, de modo que ocorrem sempre em "colônias". Tal distribuição sugere que os agrupamentos são formados por indivíduos aparentados, isto é, formados a partir de sementes germinadas ao lado das plantas-mãe, ou formados por um conjunto de sementes oriundas de um agrupamento adjacente, que foram transportadas por água de enxurrada e ali germinaram (observou-se que as plantas vegetam justamente em locais onde a água deve se acumular antes de escorrer rocha abaixo). Observou-se também que a população é restrita a apenas uma certa área, não sendo encontrado nenhum outro agrupamento além dos seis observados, apesar de os afloramentos continuarem por algumas dezenas de metros.

Foi possível observar a presença de indivíduos de menor porte, i.e., mais jovens, porém nunca de plântulas. Nenhum indivíduo estava em floração, mas muitos deles estavam produzindo sementes. No entanto, a maioria das infrutescências estava 
sendo atacada por brocas (Lepidoptera), provocando a perda de grande parte das sementes produzidas.

A distribuição das plantas sobre afloramentos as torna mais protegidas, uma vez que dificilmente poderá ser feita alguma roça ou benfeitoria neste local. Porém, por se tratar da única população conhecida, e por não estar protegida por Unidade de Conservação, a espécie está criticamente ameaçada de extinção.

\subsubsection{Encholirium. subsecundum}

E. subsecundum é uma planta de porte muito robusto e protegida por fortes acúleos, além de ter o hábito de formar grandes e densas touceiras. Por estes motivos, é uma espécie cujas populações não podem ser facilmente destruídas, estando protegida, por exemplo, do pisoteio ou pastoreio pelo gado. Além disso, vegeta diretamente sobre rochas. Observourse o hábito de formação de densas touceiras, especialmente na população 2, que era composta por aproximadamente 150 touceiras, algumas com mais de 20 rosetas. As outras populações eram bem menores, formadas por aproximadamente 20 touceiras, todas com no máximo 10 rosetas. A população 1, especialmente, foi composta de pequenos agrupamentos (de em média 7 indivíduos). Apenas na população 3 observou-se a presença de plântulas (tendo sido observadas algumas poucas, aproximadamente 5). Em todas as populações havia muitas plantas em frutificação. Apesar da presença de brocas (Lepidoptera), a produção de sementes é tamanha que não deve haver grandes prejuízos. Na população 4 observou-se a presença de ação antrópica, representada por lixo e eucaliptos (deve-se ressaltar que esta é justamente a população que ocorre dentro de uma Unidade de Conservação !). 


\subsection{Teste e seleção de primers}

Entre os 92 primers testados, 16 mostraram-se adequados, produzindo bandas robustas de boa intensidade. Entre estes, 5 foram utilizados nas reações de PCR, por gerarem mais bandas e apresentarem melhor perfil de amplificação. Os primers utilizados e suas respectivas seqüências estão na Tabela 5.

Tabela 5. Primers utilizados e suas seqüências

\begin{tabular}{cc}
\hline Primer & Seqüência $\left(5^{\prime} \rightarrow 3^{\prime}\right)$ \\
\hline OPC-06 & GAACGGACTC \\
OPE-04 & GTGACATGCC \\
OPG-08 & TCACGTCCAC \\
OPP-14 & CCAGCCGAAC \\
OPP-16 & CCAAGCTGCC \\
\hline
\end{tabular}

Análises de bootstrap, realizadas pelo programa Dboot (Coelho, 2000), foram utilizadas para estimar o número de bandas necessárias para obter associações estáveis entre todos os indivíduos de cada espécie, de acordo com Silveira et al. (2003). Os resultados podem ser visualizados nas Figuras 12, 13 e 14, que mostram a relação entre o coeficiente de variação e o número de bandas. As curvas dos gráficos indicam que a taxa de decréscimo do coeficiente de variação diminui após 50 bandas. Estes resultados sugerem que os primers utilizados foram suficientes para a análise. 


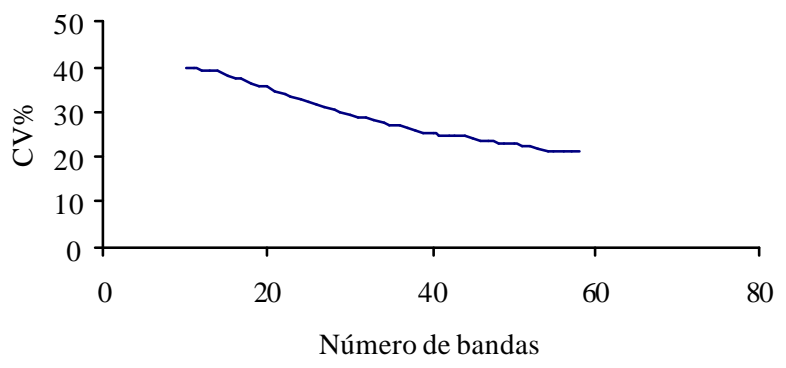

Figura 12 - Gráfico mostrando a relação entre o coeficiente de variação e o número de bandas obtidas para a espécie Encholirium biflorum

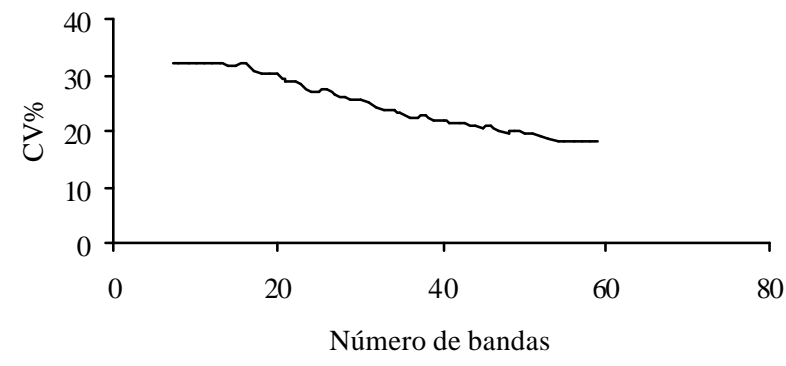

Figura 13 - Gráfico mostrando a relação entre o coeficiente de variação e o número de bandas obtidas para a espécie Encholirium pedicellatum

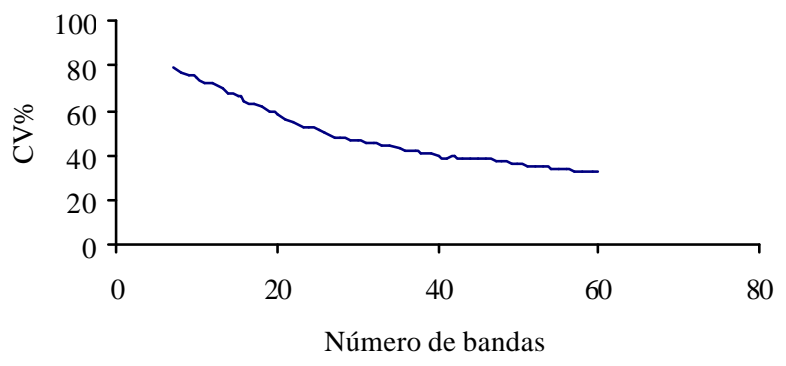

Figura 14 - Gráfico mostrando a relação entre o coeficiente de variação e o número de bandas obtidas para a espécie Encholirium subsecundum 


\subsection{Análise estatística dos dados}

Os cincos primers utilizados geraram em média 55,3 bandas polimórficas robustas para cada espécie, variando de aproximadamente 400 a aproximadamente 2300 pares de base (pb). Na Tabela 6 estão relacionados os primers que foram utilizados e o número de bandas produzidas para cada espécie.

Tabela 6. Primers utilizados e número de bandas produzidas para cada espécie. Entre parênteses, o número de bandas monomórficas

Número de Bandas

\begin{tabular}{cccc}
\hline Primer & E. biflorum & E. pedicellatum & E. subsecundum \\
\hline OPC-06 & $17(1)$ & $15(0)$ & $16(0)$ \\
OPE-04 & $10(1)$ & $09(1)$ & $14(0)$ \\
OPG-08 & $10(0)$ & $15(0)$ & $08(0)$ \\
OPP-14 & $13(1)$ & $10(1)$ & $15(0)$ \\
OPP-16 & $08(2)$ & $10(4)$ & $07(0)$ \\
Média & 11,6 & 11,8 & 12,0 \\
TOTAL & $58(5)$ & $59(6)$ & $60(0)$ \\
\hline
\end{tabular}

Para E. biflorum, cada primer gerou em média 11,6 bandas, variando de em torno de 400 a aproximadamente 2.300 pares de base. Apenas oito bandas foram produzidas pelo primer OPP-16, enquanto o primer OPC-06 gerou dezessete bandas. O primer OPG-08 não produziu nenhuma banda monomórfica, o primer OPP-16 produziu duas bandas monomórficas, e os demais, uma banda monomórfica cada.

Foram produzidas várias bandas exclusivas de agrupamentos e/ou indivíduos. Para o agrupamento 1, pode ser observada uma banda exclusiva, produzida pelo primer OPP-14, de aproximadamente 800 pares de base. $\mathrm{O}$ agrupamento 2 apresentou três bandas exclusivas, duas produzidas pelo primer OPP-14 (aproximadamente 1700 e $1250 \mathrm{pb}$ ) e uma produzida pelo primer OPC-06 (600 pb, 
exclusiva de um indivíduo). Para o agrupamento 3 geraram-se quatro bandas exclusivas, sendo duas produzidas pelo primer OPG-08 (800 e 700 pb, cada uma exclusiva de um indivíduo), uma pelo primer OPP-16 (1650 pb), e uma pelo primer OPC-06 (550 pb, sendo exclusiva de um indivíduo). Na Tabela 7 pode-se observar o número de bandas exclusivas obtidas para cada agrupamento, bem como os primers que as geraram. $\mathrm{Na}$ Figura 15, pode-se observar a fotografia de um gel de eletroforese evidenciando as bandas exclusivas geradas pelo primer OPP-14

Tabela 7. Número de bandas exclusivas produzidas para cada agrupamento de $E$. biflorum, e primers que geraram tais bandas

\begin{tabular}{ccl}
\hline Agrupamento & Número de Bandas & Primer \\
\hline 1 & 1 & OPP-14 \\
2 & 3 & OPP-14 (2), OPC-06 (1) \\
3 & 4 & OPG-08 (2), OPP-16 (1), OPC-06 (1) \\
\hline
\end{tabular}

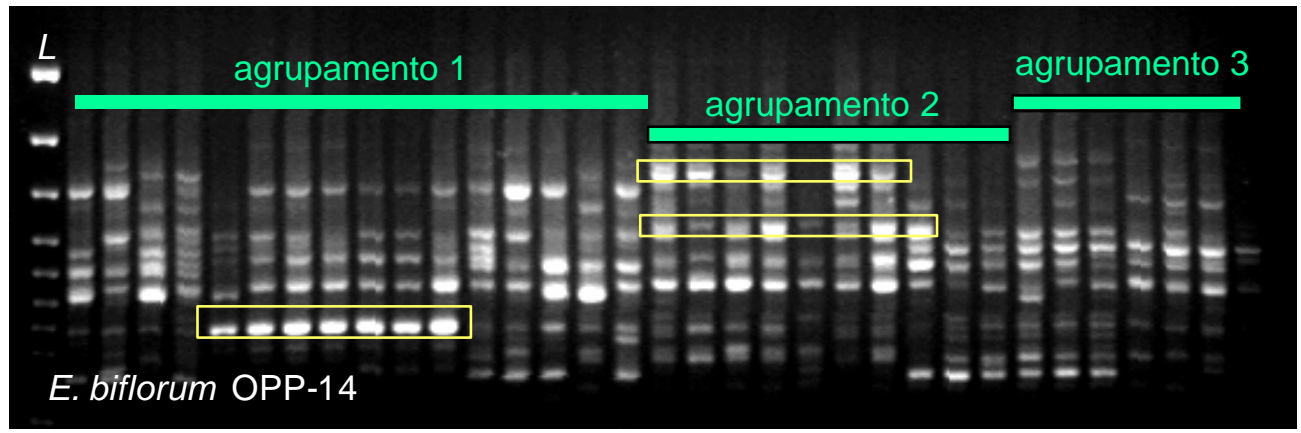

Figura 15 - Fotografia de um gel de eletroforese evidenciando as bandas exclusivas dos agrupamentos 1 e 2 (destacadas pelo retângulo amarelo), geradas pelo primer OPP-14 
Foi detectada a presença de um clone para esta espécie. O Coeficiente de Similaridade de Jaccard (S) entre os indivíduos "07" e "08", adjacentes no campo, foi igual a 1, indicando que tais plantas são geneticamente idênticas para os locos amostrados. Na população, estes dois indivíduos estão separados por alguns centímetros, evidenciando que é possível que dois indivíduos sejam clones mesmo sem ligação física entre eles (ou seja, que uma touceira pode vir a ser separada em duas), ainda que seja, conforme os resultados, um evento raro.

Para E. pedicellatum, cada primer gerou em média 11,8 bandas, sendo que o primer OPE-04 gerou o menor número de bandas (apenas nove), enquanto os primers OPG-08 e OPC-06 geraram 15 bandas cada um, sendo todas polimórficas. Das seis bandas monomórficas observadas, quatro foram geradas pelo primer OPP-16, uma pelo primer OPE-04 e uma pelo primer OPP-14. Todas as bandas possuem aproximadamente de 500 a 2100 pares de base.

Nenhuma das bandas produzidas mostrou-se exclusiva de algum agrupamento ou indivíduo. Não foi detectada a presença de clones.

No caso de E. subsecundum, cada primer gerou em média 12 bandas, sendo todas polimórficas, variando de 400 a 2000 pares de base. O primer OPP-16 gerou apenas sete bandas, enquanto que o primer OPC-06 gerou dezesseis bandas.

Não foi produzida nenhuma banda exclusiva de uma população ou agrupamento, mas foi possível observar a ausência de determinadas bandas em determinadas populações. As ausências observadas podem ser "ausências exclusivas", isto é, todas as populações possuem determinada banda, com exceção de uma determinada população, ou podem ser "ausências compartilhadas", isto é, determinada banda está ausente em duas populações e presente nas outras duas.

A população 1, por exemplo, apresenta quatro ausências exclusivas (duas produzidas pelo primer OPE-04, de 600 e 1400 pb, e duas produzidas pelo primer OPC06, de 1200 e 1100 pb). A população 2 apresenta uma ausência exclusiva (primer OPG08, $1200 \mathrm{pb}$ ) e uma ausência compartilhada com a população 3 (primer OPC-06, 850 pb). A população 3 apresenta três ausências exclusivas (duas pelo primer OPE-04, de 1050 e 850 pb, e uma pelo primer OPG-08, 850 pb) e três ausências compartilhadas 
(uma com a população 2, já citada, e duas com a população 4, pelos primers OPE-04 e OPP-14, com 1300 e 2000 pb, respectivamente). A população 4 apresenta cinco ausências exclusivas (três pelo primer OPC-06, de 1200, 1050 e 900 pb, uma pelo primer OPP-16, de 1500 pb, e uma pelo primer OPG-08, de 550 pb), e duas ausências compartilhadas com a população 3 (já citadas).

Pode-se observar que as populações 3 e 4 compartilham o maior número de ausências (duas), seguidas das populações 2 e 3 (compartilhando uma ausência). A população 4 possui o maior número de ausências exclusivas (5), seguida pelas populações 1, 3 e 2 (4, 3 e 1 ausência, respectivamente). Não foi encontrado nenhum clone para esta espécie. Um resumo das ausências de banda observadas para cada agrupamento de E. subsecundum pode ser observado na Tabela 8, onde estão relacionados também os primers que produziram bandas nos demais agrupamentos. $\mathrm{Na}$ Figura 16 pode-se observar a fotografia de um gel de eletroforese evidenciando a ausência exclusiva de uma banda na população 4, gerada nas demais populações pelo primer OPP-16.

Tabela 8. Número ausências de banda exclusivas; número de ausências de banda compartilhadas por par de populações e relação dos primers que produziram bandas nas demais populações

\begin{tabular}{ccc}
\hline População & Número de bandas ausentes & Primer \\
\hline 1 & 4 & OPE-04 (2), OPC-06 (2) \\
2 & 1 & OPG-08 \\
3 & 3 & OPE-04 (2), OPG-08 (1) \\
4 & 5 & OPC-06 (3), OPP-16 (1), OPG-08 (1) \\
2 e $3^{*}$ & 1 & OPC-06 \\
3 e $4^{*}$ & 2 & OPE-04, OPP-14 \\
\hline
\end{tabular}

* Ausências compartilhadas 


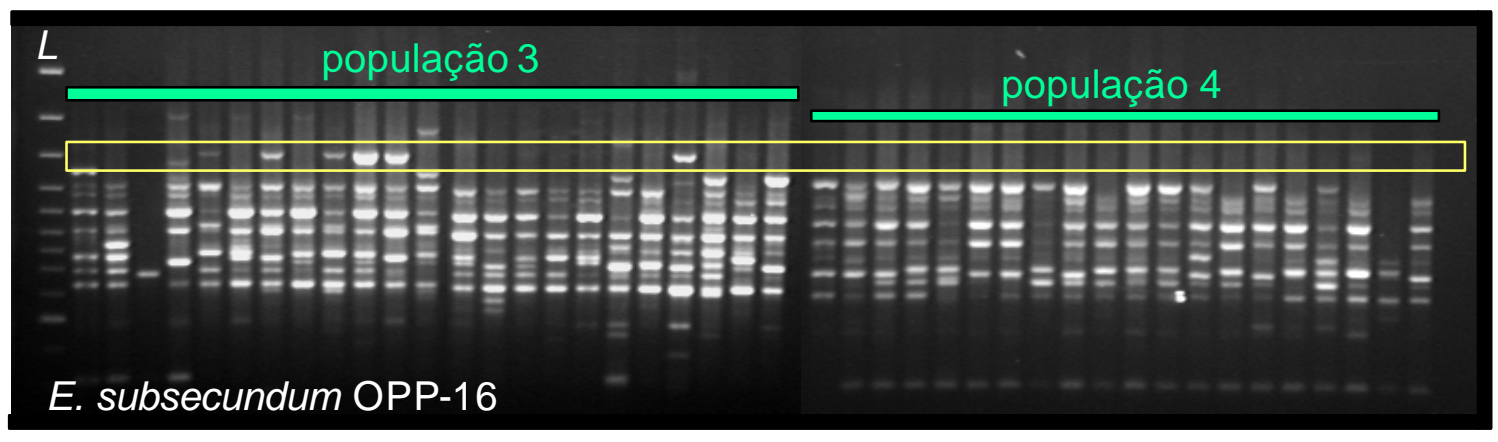

Figura 16 - Fotografia de um gel de eletroforese evidenciando a ausência exclusiva de uma banda na população 4 (destacada pelo retângulo amarelo), gerada nas demais populações pelo primer $\mathrm{OPP}-16$. As populações 1 e 2 não aparecem na figura.

Os dendrogramas gerados pelo método UPGMA estão ilustrados nas Figuras 17, 18, 19 e 20. Pode-se observar que não necessariamente os agrupamentos ou populações espacialmente mais próximos foram agrupados. É possível que as distâncias físicas entre os agrupamentos sejam pequenas demais para que se possa relacioná-las com a similaridade genética molecular observada entre eles.

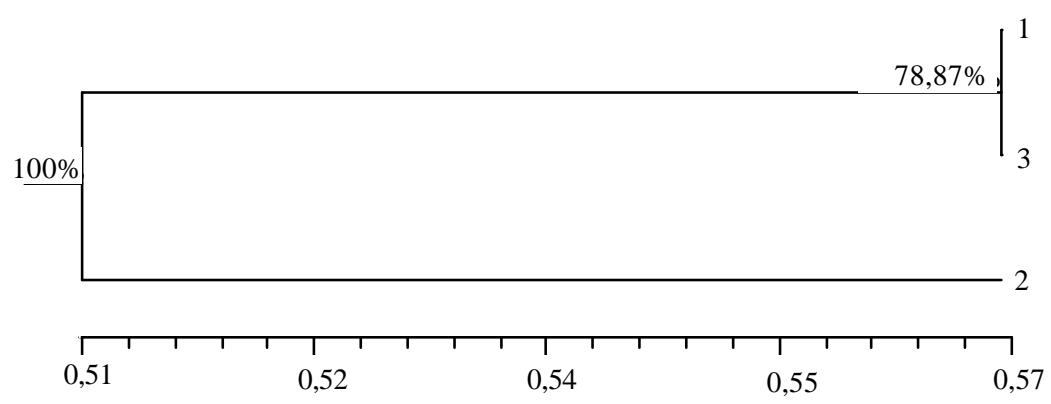

Figura 17 - Dendrograma obtido para os agrupamentos de E. biflorum Os valores junto aos "nós" representam sua estabilidade, testada através de bootstraps. Os números abaixo dos dendrogramas são os valores do índice de similaridade de Jaccard $(S)$ 


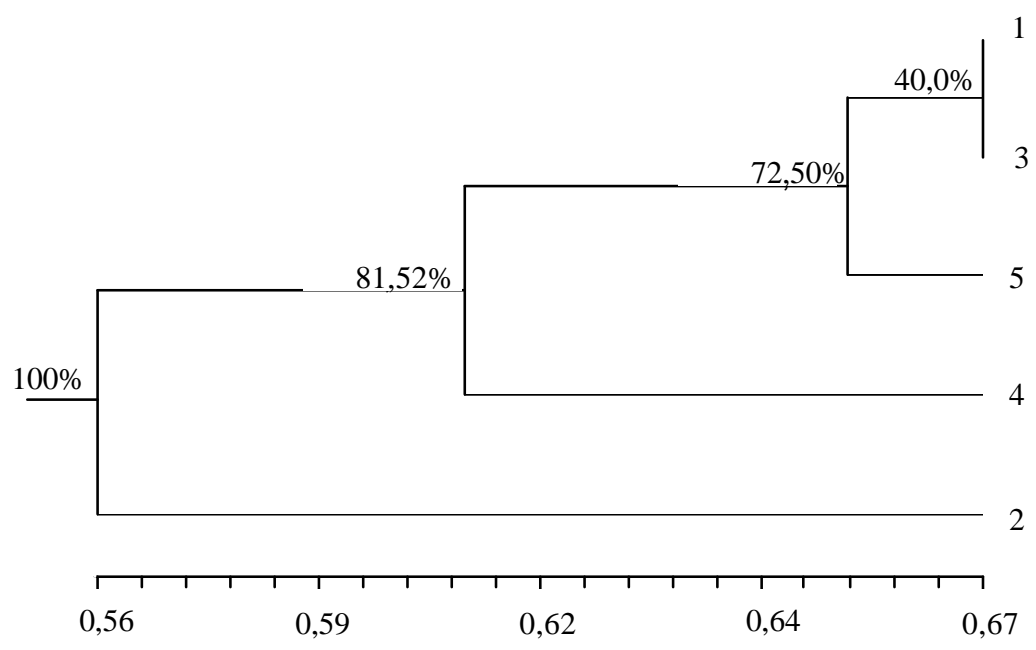

Figura 18 - Dendrograma obtido para os agrupamentos de E. pedicellatum. Os valores junto aos "nós" representam sua estabilidade, testada através de bootstraps. Os números abaixo dos dendrogramas são os valores do índice de similaridade de Jaccard $(S)$

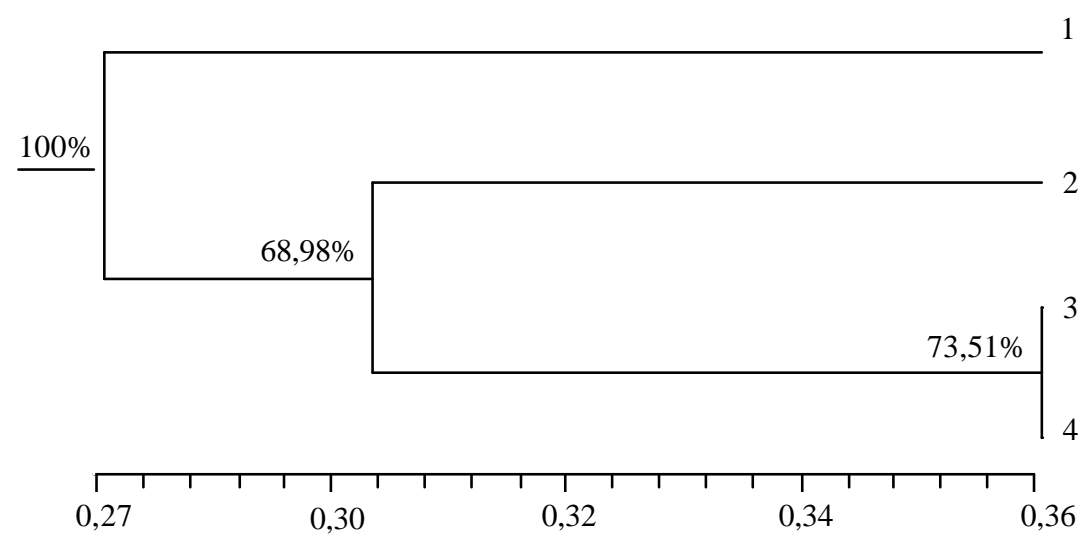

Figura 19 - Dendrograma obtido para as populações de E. subsecundum. Os valores junto aos "nós" representam sua estabilidade, testada através de bootstraps. Os números abaixo dos dendrogramas são os valores do índice de similaridade de Jaccard $(S)$ 


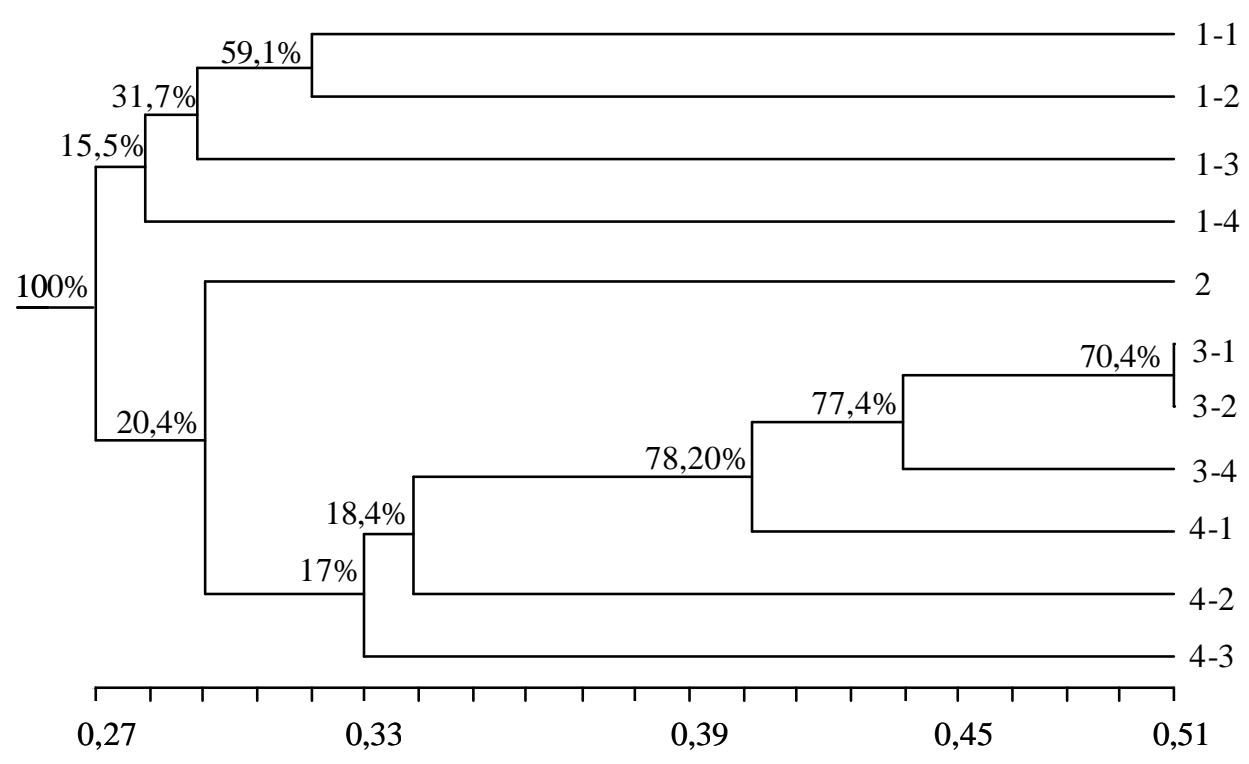

Figura 20 - Dendrograma obtido para os agrupamentos de E. subsecundum. Cada agrupamento está representado por dois algarismos: o primeiro refere-se à população de origem, e o segundo, ao número do agrupamento dentro da população. Os valores junto aos "nós" representam sua estabilidade, testada através de bootstraps. Os números abaixo dos dendrogramas são os valores do índice de similaridade de Jaccard $(S)$

A técnica molecular de marcadores RAPD permitiu observar que cada indivíduo amostrado apresenta um genótipo diferente para os locos amostrados (com exceção de um clone encontrado para E. biflorum). Em E. biflorum, conforme as observações de campo, devido à alta densidade de indivíduos dentro dos agrupamentos, esperava-se que estes fossem formados por apenas um ou poucos clones, o que não foi verificado. Mesmo para as demais espécies, este resultado não era esperado, uma vez que as três espécies apresentam hábito clonal formando densos agrupamentos, morfologia uniforme e tamanho reduzido de populações. 
Fischer et al. (2000), encontraram resultados semelhantes ao estudar a estrutura genética de populações de Ranunculus reptans (Ranunculaceae) nos Alpes. Trata-se de uma espécie pouco agressiva, restrita às margens de alguns lagos, onde a competição com outras espécies é reduzida devido às inundações sazonais. São plantas auto-incompatíveis e clonais, propagando-se através de sementes e de brotações laterais ao longo de estolões, formando densos agrupamentos. Os autores realizaram amostragens a cada $5 \mathrm{~m}$ ao longo de transectos, coletando ao todo 127 amostras. Encontraram 124 diferentes fenótipos RAPD. Os três pares de amostras com o mesmo fenótipo RAPD foram coletados em distâncias menores $(25 \mathrm{~cm})$, e os autores assumem que pertencem ao mesmo geneto. Os resultados, segundo os autores, sugerem que diferentes clones ocorrem mesmo dentro dos menores agrupamentos (patches) nas menores populações.

O elevado número de diferentes genótipos detectado para as três espécies é contrastante com a aparentemente reduzida participação da reprodução sexuada na formação das populações. Em E. biflorum, de acordo com observações de Forzza ao longo de anos, raramente observam-se flores ou frutos na população. Em $E$. pedicellatum, na ocasião da coleta de material para este trabalho (maio de 2003), havia alguns indivíduos em frutificação, porém a maioria das infrutescências estava danificada por brocas, reduzindo severamente o número de sementes íntegras. Em E. subsecundum há grande produção de sementes em relação a E. pedicellatum. Porém, mesmo nas populações de E. subsecundum, raramente são observadas plantas jovens. As populações parecem ser compostas apenas por plantas adultas, de porte bastante grande e robusto. Como estas plantas demoram anos para atingir a maturidade, poder-se-ia esperar encontrar plantas mais jovens, porém isto não é observado na natureza. Assim, para as três espécies, o estabelecimento de plântulas nas populações parece ser um evento raro.

Muitos outros autores que pesquisaram plantas clonais observaram uma pequena participação da reprodução sexuada para a formação das populações. Na gramínea estolonífera Oryza alta, nativa das várzeas do Vale do Ribeira, SP, contagens de colmos novos brotando do solo mostraram que mais de $95 \%$ deles eram originários de reprodução vegetativa e que a participação das sementes na reposição da população é 
insignificante, a despeito da enorme produção de sementes dessa espécie (Giancarlo Oliveira, comunicação pessoal). Persson \& Gustavsson (2001), relatam que não se observa o estabelecimento de plântulas em populações estabelecidas de Vaccinium vitisideae, uma Ericaceae de hábito clonal. Para a Poaceae Calamagrostis porteri ssp. insperata, Esselman et al. (1999), relatam que a ocasional floração, a alta taxa de aborto de embriões e a baixa taxa de germinação de sementes contribuem para que a reprodução sexuada nesta espécie seja um raro evento. Os autores, porém, detectaram um grande número de diferentes genótipos. Três hipóteses foram então levantadas para explicar a elevada variabilidade genética encontrada. A primeira seria a hipótese de que a reprodução sexual ocasional gera novos genótipos, que são mantidos e propagados vegetativamente. Assim, após muitos anos, mesmo que a reprodução sexual seja um evento raro, muitos genótipos diferentes se acumulam na população. A segunda hipótese seria a de que a reprodução sexual teria sido mais freqüiente no passado. Desta forma, muitos genótipos teriam sido criados, e estariam presentes nas populações até hoje devido à manutenção através da propagação vegetativa. Por fỉm, podem ocorrer mutações somáticas. Nenhuma das hipóteses exclui as demais. Nos três casos, é o hábito clonal que mantém os genótipos nas populações por muitos anos. Estas hipóteses parecem ser aplicáveis aos resultados encontrados para as três espécies de Encholirium.

Kreher et al. (2000), propõem hipóteses semelhantes para explicar a diversidade encontrada entre indivíduos da espécie clonal Vaccinium stamineum. Segundo os autores, populações de plantas clonais são supostamente compostas por um ou poucos genetos localmente adaptados, porém isto raramente é observado. Indivíduos gerados a partir de sementes e mutações somáticas adicionam diversidade genética à estas populações. Além disso, devido à possível longevidade das plantas proporcionada pela propagação vegetativa, a diversidade genética existente na população fundadora pode ser mantida. Conforme os autores, populações de espécies clonais são fundadas por sementes e gradativamente aumentam a propagação vegetativa em detrimento da reprodução sexuada. Distúrbios no ambiente podem, no caso da espécie estudada, criar oportunidades ("windows of opportunity") para o estabelecimento de plântulas. Sharma (2001), sugere ainda que a seleção diferencial em ambientes espacialmente heterogêneos 
também pode explicar um elevado número de diferentes genótipos em populações de plantas clonais.

Com relação à diversidade genética molecular total detectada para cada espécie, os resultados indicam que E. subsecundum apresenta a maior diversidade entre as três, seguida de E. biflorum, e por último, E. pedicellatum. Isso pode ser observado tanto através da porcentagem de bandas polimórficas, PPB, quanto através do Índice de Diversidade de Shannon-Wiener e da dissimilaridade (D) de Jaccard (Tabela 9).

No caso de E. subsecundum, foram produzidas 60 bandas, sendo todas (100\%) polimórficas. Para E. biflorum, os cinco primers utilizados produziram 58 bandas, sendo $53(91,37 \%)$ polimórficas. Para E. pedicellatum, foram geradas 59 bandas robustas, das quais $53(89,8 \%)$ mostraram-se polimórficas.

Os valores encontrados para o Índice de Diversidade de Shannon-Wiener foram os seguintes: E. subsecundum: $H=0,401 ; E$. biflorum: $H=0,322 ;$ E. pedicellatum: $H=0,298$.

Os valores de dissimilaridade $(D)$ encontrados para cada espécie, calculados a partir da média de $D$ observado entre cada par de indivíduos, foram os seguintes: E. subsecundum: $D=0,69 ;$ E. biflorum: $D=0,48 ;$ E. pedicellatum: $D=0,40$.

Tabela 9. Diversidade genética molecular total de cada espécie de acordo com $H, D$ e $P P B ; n$ é o tamanho da amostra (número de indivíduos)

\begin{tabular}{cccc}
\hline Parâmetro & $\begin{array}{c}\text { E. subsecundum } \\
(\mathrm{n}=77)\end{array}$ & $\begin{array}{c}\text { E. pedicellatum } \\
(\mathrm{n}=31)\end{array}$ & $\begin{array}{c}\text { E. biflorum } \\
(\mathrm{n}=31)\end{array}$ \\
\hline PPB $^{*}$ & $100 \%$ & $91,37 \%$ & $89,80 \%$ \\
$\mathrm{H}^{* *}$ & 0,401 & 0,322 & 0,298 \\
$\mathrm{D}^{* * *}$ & 0,69 & 0,48 & 0,40 \\
\hline
\end{tabular}

*PPB $=$ porcentagem de bandas polimórficas

** $\mathrm{H}=$ índice de diversidade de Shannon-Wiener

*** $\mathrm{D}=$ dissimilaridade 
Neste caso, a espécie mais amplamente distribuída, com mais populações e com o maior número de indivíduos amostrados é a que apresenta maior diversidade genética molecular, o que é normalmente esperado (mas não é regra). Karron et al., (1988), por exemplo, estudou a estrutura genética de populações de espécies restritas e de ampla distribuição do gênero Astragalus (Fabaceae), encontrando menores níveis de diversidade genética nas espécies restritas. No entanto, a diversidade observada para $E$. subsecundum, apesar de maior, não é muito superior à observada para as outras duas espécies, de modo que a utilização de outros primers, por exemplo, poderia vir a inverter os resultados (isto é, os resultados obtidos podem ser devidos ao erro amostral, e não à distribuição ampla de E. subsecundum).

Os valores encontrados para o Índice de Diversidade de Shannon-Wiener para cada população de E. subsecundum foram os seguites: população1: $H=0,360$; população 2: $H=0,368$; população 3: $H=0,300$; população 4: $H=0,294$. Os valores de $D$ encontrados para cada população, calculados a partir da média de valores $D$ observados entre cada par de indivíduos dentro de cada população, foram os seguintes: população1: $D=0,70$; população 2: $D=0,67$; população $3: D=0,53$; população 4: $D=0,64$. Na Tabela 10 podem-se observar os valores encontrados para a diversidade genética molecular total de cada população, através de cada um dos parâmetros utilizados $(H$ e $D)$.

Tabela 10. Diversidade das populações de E. subsecundum de acordo com $H$ e $D ; n$ é o tamanho da amostra (número de indivíduos)

\begin{tabular}{lccc}
\hline & $\mathrm{H}^{*}$ & $\mathrm{D} * *$ & $\mathrm{n}$ \\
\hline População 1 & 0,360 & 0,70 & 23 \\
População 2 & 0,368 & 0,67 & 25 \\
População 3 & 0,300 & 0,53 & 18 \\
Populąão 4 & 0,294 & 0,64 & 11 \\
\hline
\end{tabular}

*H= índice de diversidade de Shannon-Wiener

$* * \mathrm{D}=$ dissimilaridade 
Pode-se observar que os valores de $H$ encontrados são maiores nas populações com mais indivíduos. Já os valores de $D$ não se mostram tão fortemente relacionados com o número de indivíduos nas populações. Esses resultados podem ser devido ao erro amostral, sem que haja relação com o número de indivíduos em cada população.

Os resultados permitem ainda comparar cada uma das populações de $E$. subsecundum com as populações de E. biflorum e E. pedicellatum (Tabela 11). Pode-se observar que todas as populações de $E$. subsecundum apresentam o valor de $D$ superior, e praticamente todas apresentam valor de $H$ superior aos valores encontrados para as duas espécies restritas, mesmo apresentando menores tamanhos amostrais. Esta observação evidencia que os valores encontrados para E. subsecundum como um todo são superiores aos valores encontrados para as outras duas espécies não devido ao maior número de indivíduos amostrados, mas sim devido à maior diversidade genética molecular ocasionada pelo fato da espécie possuir várias populações e ser mais amplamente distribuída.

Tabela 11. Diversidade das populações das três espécies de acordo com $H$ e $D ; n$ é o tamanho da amostra (número de indivíduos)

\begin{tabular}{lccc}
\hline & $\mathrm{H}^{*}$ & $\mathrm{D}^{* *}$ & $\mathrm{n}$ \\
\hline E. subsecundum total & 0,401 & 0,69 & 77 \\
E. subsecundum População 1 & 0,360 & 0,70 & 23 \\
E. subsecundum População 2 & 0,368 & 0,67 & 25 \\
E. subsecundum Populção 3 & 0,300 & 0,53 & 18 \\
E. subsecundum Populacão 4 & 0,294 & 0,64 & 11 \\
E. biflorum & 0,298 & 0,40 & 31 \\
E. pedicellatum & 0,322 & 0,48 & 31 \\
\hline
\end{tabular}

$$
\begin{aligned}
& * \mathrm{H}=\text { índice de diversidade de Shannon-Wiener } \\
& * * \mathrm{D}=\text { dissimilaridade }
\end{aligned}
$$


Com relação à AMOVA, para E. biflorum, a análise detectou diversidade genética molecular altamente significativa $(\mathrm{P}<0,001)$ tanto entre os agrupamentos como entre os indivíduos do mesmo agrupamento. Do total da variância genética molecular encontrada para a espécie, $16,06 \%$ se deve às divergências entre agrupamentos, enquanto que $83,94 \%$ é atribuída às diferenças entre indivíduos dentro de agr upamentos. $\mathrm{O} \Phi_{\text {st }}$ observado para esta espécie foi, portanto, igual a 0,16 (Tabela 12).

Tabela 12. Resultado da AMOVA para E. biflorum

\begin{tabular}{lccccc}
\hline FV & GL & SQ & \% da Variação & P & Estatística $\Phi$ \\
\hline $\begin{array}{l}\text { Entre } \\
\text { agrupamentos }\end{array}$ & 2 & 28,179 & $16,06 \%$ & $(<0,001)^{* *}$ & $\Phi_{\mathrm{ST}}=0,1606$ \\
$\begin{array}{l}\text { Entre indivíduos } \\
\text { dentro de }\end{array}$ & & & & & \\
$\begin{array}{l}\text { agrupamentos } \\
\text { TOTAL }\end{array}$ & 28 & 141,434 & $83,94 \%$ & $(<0,001)^{* *}$ & $1-\Phi_{\mathrm{ST}}=0,8394$ \\
\hline
\end{tabular}

** altamente significativo

Para E. pedicellatum, o resultado da AMOVA, (Tabela 13) indica que há diversidade genética molecular altamente significativa $(\mathrm{P}<0,001)$ tanto entre agrupamentos como entre indivíduos do mesmo agrupamento. Do total da variância genética molecular encontrada para a espécie, $8,44 \%$ se deve às divergências entre agrupamentos, enquanto que $91,56 \%$ é atribuída às diferenças entre indivíduos dentro de agrupamentos, sendo $\Phi_{\mathrm{st}}=0,08$. 
Tabela 13. Resultado da AMOVA para E. pedicellatum

\begin{tabular}{lccccc}
\hline FV & GL & SQ & \% da Variação & P & Estatística $\Phi$ \\
\hline $\begin{array}{l}\text { Entre } \\
\text { agrupamentos }\end{array}$ & 4 & 26,560 & $8,44 \%$ & $(<0,001) * *$ & $\Phi_{\mathrm{ST}}=0,084$ \\
$\begin{array}{l}\text { Entre indivíduos } \\
\text { dentro de }\end{array}$ & & & & & \\
$\begin{array}{l}\text { agrupamentos } \\
\text { TOTAL }\end{array}$ & 26 & 110,214 & $91,56 \%$ & $(<0,001)^{* * *}$ & $1-\Phi_{\mathrm{ST}}=0,9156$ \\
\hline & 30 & 136,774 & & & \\
$* *$ altamente significativo & & & & & \\
\end{tabular}

Com relação aos resultados da AMOVA, observa-se que cada uma das espécies apresenta um padrão de distribuição da variabilidade genética molecular diferente. As diferenças genéticas moleculares que existem entre os agrupamentos de $E$. biflorum são responsáveis por 16,06\% da variância genética molecular total da espécie. Este valor é praticamente o dobro do observado para os agrupamentos de $E$. pedicellatum. É interessante notar que os agrupamentos de E. biflorum estão distantes entre si em média $11,33 \mathrm{~m}$, enquanto que os de E. pedicellatum estão distantes entre si em média $88 \mathrm{~m}$. Os resultados indicam que há mais fluxo gênico entre os agrupamentos de E. pedicellatum do que entre os agrupamentos de E. biflorum, apesar de as distâncias serem bem maiores em E. pedicellatum. De acordo com os resultados, há estruturação em nível de agrupamentos para as duas espécies, sendo esta estruturação bem mais forte em E. biflorum.

Conforme Chung et al. (1999), a estrutura genética espacial dentro de populações é determinada principalmente pelos efeitos da dispersão limitada de pólen e sementes. A espécie E. biflorum raramente foi observada em floração ou frutificação, de modo que sua biologia reprodutiva é desconhecida. É possível que as florações sejam irregulares, com poucos indivíduos florescendo ao mesmo tempo na população, o que ocasionaria um limitado fluxo gênico. Já em E. pedicellatum, na ocasião da coleta de material para este trabalho, por exemplo, vários indivíduos estavam produzindo 
sementes, sugerindo que as florações são sincronizadas entre os indivíduos dos vários agrupamentos. Como as distâncias entre agrupamentos (em média 88 m) são facilmente cobertas pelos prováveis agentes polinizadores (beija-flores ou morcegos), o fluxo de pólen seria responsável pela diminuição da divergência entre agrupamentos. Quanto ao fluxo gênico ocasionado pelas sementes, acredita-se que seja muito limitado. As sementes das três espécies de Encholirium estudadas apresentam baixo poder de dispersão, não sendo carregadas pelo vento ou por nenhum animal. Sempre atingem o solo em locais próximos da planta mãe, a não ser que sejam carregadas pela água de enxurrada (de acordo com Christianini et al., em fase de elaboração, a maturação das sementes de E. vogelli e E. heloisae, por exemplo, coincide com a época das chuvas, e os autores sugerem que as águas podem ter grande participação na dispersão das sementes). Esta dispersão limitada de sementes favorece o estabelecimento de plântulas junto da planta-mãe, e pode ser, em grande parte, responsável pela estruturação em agrupamentos observada. Em E. pedicellatum, observou-se que a maioria dos agrupamentos está em locais onde a água se acumula antes de escorrer, de modo que estes podem ser formados por sementes oriundas de um agrupamento situado logo acima no afloramento. Isto resultaria em indivíduos aparentados dentro de agrupamentos e também entre agrupamentos, provocando uma certa estruturação, porém menor do que em E. biflorum, onde o terreno é plano e as sementes germinam apenas nos agrupamentos de origem. Tais hipóteses são apenas especulativas, sendo necessários estudos mais aprofundados para a compreensão dos resultados obtidos.

Padrões semelhantes de estruturação em agrupamentos já foram relatados para outras espécies clonais. Por exemplo, foi observado em $R$. reptans, por Fischer et al. (2000), que há diferenças genéticas significativas entre subpopulações dentro de populações. Segundo os autores, este resultado sugere que a dispersão de sementes é muito limitada e que o pólen é disperso a curtas distâncias dentro das populações. Kreher et al. (2000), também encontraram divergência genética molecular entre agrupamentos de $V$. stamineum. De acordo com seus resultados, amostras dentro de agrupamentos (patches) são mais similares entre si do que entre amostras de outros agrupamentos, indicando que os fundadores dos agrupamentos eram aparentados ou que 
as plântulas subsequientes germinaram próximas da planta-mãe. Ayres \& Ryan (1999), sugerem que a limitada produção de sementes e a baixa taxa de sobrevivência de plântulas são os principais fatores que causam diferenciação entre populações de Wyethia reticulata, uma espécie estolonífera endêmica da Califórnia.

No caso de E. subsecundum, AMOVA (Tabela 14) detectou diversidade genética molecular altamente significativa $(\mathrm{P}<0,001)$ entre as populações, porém não significativa entre os agrupamentos $(\mathrm{P}>0,05)$. Do total da variância genética molecular encontrada para a espécie, 14,52\% se deve às divergências entre populações, enquanto que $84,38 \%$ é atribuída às diferenças entre indivíduos dentro de agrupamentos. As diferenças entre agrupamentos equivalem a apenas $1,10 \%$ do total da variância genética. O $\Phi_{\text {st }}$ observado para esta espécie foi, portanto, igual a 0,15 .

Tabela 14. Resultados da AMOVA para E. subsecundum

\begin{tabular}{lccccc}
\hline FV & GL & SQ & \% da Variação & P & Estatística $\Phi$ \\
\hline $\begin{array}{l}\text { Entre populações } \\
\text { Entre }\end{array}$ & 3 & 71,675 & $14,52 \%$ & $(<0,001)^{* *}$ & $\Phi_{\mathrm{CT}}=0,1452$ \\
$\begin{array}{l}\text { agrupamentos } \\
\text { dentro de }\end{array}$ & & & & & \\
$\begin{array}{l}\text { populações } \\
\text { Entre indivíduos }\end{array}$ & 7 & 41,648 & $1,10 \%$ & $(>0,05)^{\mathrm{ns}}$ & $\Phi_{\mathrm{SC}}=0,0128$ \\
$\begin{array}{l}\text { dentro de } \\
\text { agrupamentos }\end{array}$ & 66 & 362,433 & $84,38 \%$ & $(<0,001)^{* *}$ & $1-\Phi_{\mathrm{ST}}=0,8438$ \\
TOTAL & 76 & 475,156 & & & \\
\hline
\end{tabular}

** altamente significativo;

ns não significativo 
Na espécie E. subsecundum, as diferenças entre os agrupamentos são responsáveis por apenas aproximadamente $1 \%$ da variância genética molecular total. Isto não significa que os agrupamentos dentro de populações são similares entre si, unidos por fluxo gênico. Existe divergência genética molecular entre os agrupamentos de $E$. subsecundum, pois o valor obtido para $D$ "entre indivíduos de agrupamentos da mesma população" (Tabela 15) é igual a 0,64 . Os valores de $D$ não descrevem a distribuição da diversidade genética molecular: servem aqui somente para evidenciar que os agrupamentos de E. subsecundum também guardam certa divergência entre si.

Tabela 15. Valores médios de $D$

\begin{tabular}{lccc}
\hline & E.biflorum & E. pedicellatum & E. subsecundum \\
\hline $\begin{array}{l}\text { Entre indivíduos } \\
\begin{array}{l}\text { Entre indivíduos do mesmo } \\
\text { agrupamento }\end{array}\end{array}$ & 0,48 & 0,40 & 0,69 \\
$\begin{array}{l}\text { Entre indivíduos de } \\
\text { agrupamentos diferentes }\end{array}$ & 0,44 & 0,37 & 0,60 \\
$\begin{array}{l}\text { Entre indivíduos de } \\
\text { populações diferentes }\end{array}$ & 0,50 & 0,40 & $0,64^{*}$ \\
\hline
\end{tabular}

* agrupamentos diferentes dentro da mesma população

Um valor próximo do observado para os agrupamentos de E. biflorum é encontrado entre populações de E. subsecundum (14,52\%). De maneira grosseira, podese dizer que o fluxo gênico entre estas populações (distantes em média 116,66 km) é um pouco maior do que entre os agrupamentos de E. biflorum (distantes em média 11,3m). $\mathrm{Na}$ realidade, provavelmente o fluxo gênico entre as quatro populações de $E$. subsecundum se dá através de fluxo entre várias populações intermediárias que não foram amostradas. O elevado número de indivíduos em floração observado para $E$. subsecundum, e o fato de que esta espécie produz flores durante o ano todo, com maior 
intensidade entre os meses de dezembro e março, facilitam o fluxo de pólen entre agrupamentos e populações, reduzindo a divergência genética molecular entre estas unidades. Como elemento comparativo em táxons próximos, E. vogellie E. heloisae têm sincronia da floração entre as diversas populações destas espécies, permitindo assim o fluxo de pólen (Christianini et al., em fase de elaboração).

E. subsecundum é uma espécie que apresenta protoginia, mecanismo que evita a auto-fecundação (Sazima et al., 1989), e portanto esta espécie possui como sistema reprodutivo a alogamia. Espécies de plantas alógamas normalmente apresentam entre 10 e $20 \%$ da sua variância genética entre populações (Hamrick \& Godt, 1989). O resultado da AMOVA realizada para a espécie E. subsecundum foi, portanto, coerente, mostrando que $14,52 \%$ da variância genética molecular desta espécie ocorre entre populações.

Resultados semelhantes foram obtidos por diversos autores que estudaram a estrutura genética de plantas preferencialmente alógamas. Lacerda et al. (2001), ao estudarem a estrutura genética de populações de vinhático, Plathymenia reticulata, uma árvore dos cerrados, encontraram que do total da variabilidade genética molecular da espécie, 12,3\% é atribuído às diferenças entre as seis populações estudadas. Segundo os autores, de acordo com a interpretação das estatísticas F de Wright, podem-se considerar as populações amostradas como moderadamente diferenciadas. Gillies et al. (1999), realizaram estudos sobre a estrutura genética de populações de mogno, Swietenia macrophylla, espécie alógama obrigatória com sementes relativamente pesadas. Como em muitas outras árvores tropicais, a densidade de indivíduos é de menos de um indivíduo por hectare. Os autores amostraram 20 populações em três regiões geográficas. Observaram que do total da variância genética molecular, 12,01\% é atribuído às diferenças entre populações, e apenas $0,57 \%$ às diferenças entre regiões, ficando o restante $(87,43 \%)$ entre os indivíduos dentro de populações. Em Araucaria araucana, uma conífera sul-americana, Bekessy et al. (2002), encontraram 12,8\% da variabilidade total entre as 13 populações amostradas. A espécie é normalmente dióica, polinizada pelo vento e com sementes dispersas geralmente por gravidade. Para a gramínea Buchloe dactyloides, uma espécie dióica, Huff et al. (1993), encontraram 
$19,5 \%$ do total da variância genética molecular devido às divergências entre as duas populações coletadas no Texas, de modo que as divergências entre os indivíduos são responsáveis pelos $80,5 \%$ restantes da variância total observada.

Resultados similares foram obtidos para o nível de agrupamentos de $E$. pedicellatum e E. biflorum (8,44\% e 16,06\%, respectivamente). De acordo com Hamrick \& Godt, (1989), plantas preferencialmente autógamas apresentam populações geneticamente mais divergentes, sendo estas diferenças responsáveis por em torno de $50 \%$ da variância genética molecular total. Se esta assertiva for aplicável ao nível de agrupamentos de E. pedicellatum e E. biflorum, onde não há o nível hierárquico de populações, pode-se dizer que o sistema reprodutivo destas espécies é provavelmente preferencialmente alógamo, caso contrário os agrupamentos seriam mais divergentes.

Em resumo, a maior parte da variância genética molecular, nas três espécies, encontra-se entre indivíduos. As três espécies apresentam um padrão de distribuição da variabilidade genética molecular que é normalmente encontrado em espécies alógamas. A estruturação em agrupamentos varia de espécie para espécie. Todo este quadro é resultado do baixo poder de dispersão das sementes e do fluxo de pólen variável de espécie para espécie entre as unidades (agrupamentos e populações). 


\subsection{Implicações para conservação}

\subsubsection{Conservação ex situ}

Conforme os resultados, de modo geral, cada indivíduo, nas três espécies estudadas, apresenta um genótipo diferente para os locos amostrados. Este resultado tem implicação para futuras amostragens, que devem, portanto, contemplar o maior número de indivíduos quanto possível. Antes da análise, acreditava-se que poucos indivíduos seriam necessários para representar a variabilidade destas espécies. Adicionalmente, de acordo com os resultados da AMOVA, as diferenças genéticas moleculares existentes entre os indivíduos são responsáveis por grande parte da variabilidade das três espécies (maior do que $80 \%$ da variabilidade nos três casos). Este resultado evidencia que a retirada de um único indivíduo do habitat implica em perda significativa de diversidade genética na natureza. Isto é, deve-se evitar ao máximo retirar plantas das populações, mesmo que seja para compor reservas ex situ.

Para a composição de bancos de germoplasma ex situ, ou para estudos de qualquer natureza, portanto, devem-se retirar apenas sementes das populações. $\mathrm{O}$ impacto da retirada de sementes é bastante reduzido, uma vez que a grande maioria delas não chega a germinar no campo. Adicionalmente, a taxa de germinação destas sementes em laboratório tem se mostrado elevada, conforme Borges (em fase de elaboração). Os autores estudaram a taxa de germinação de sementes das espécies E. subsecundum, E. pedicellatum, E. heloisae, E. magalhaesii, E. reflexum e E. scrutor, após diferentes tratamentos, observando elevadas taxas em todas as espécies (de 70 a 95\%). Para E. pedicellatum, observou-se uma taxa de germinação superior a $90 \%$, enquanto que para E. subsecundum, a taxa de germinação atingiu $80 \%$. A desidratação, na maioria das espécies, não afetou a germinação. Sementes desidratadas, armazenadas por 6 meses a $4^{\circ}$ $\mathrm{C}$ e $-20^{\circ} \mathrm{C}$ tiveram suas taxas de germinação aumentadas na maioria das espécies. Em $E$. subsecundum, o congelamento de sementes não desidratadas em $\mathrm{N}_{2}$ líquido promoveu o aumento da taxa de germinação. Tais resultados mostram que a utilização de sementes

para a composição de bancos de germoplasma de espécies de Encholirium é totalmente 
viável, havendo, no entanto, a necessidade de ajuste do método de armazenamento para cada espécie.

No caso da dificuldade em se obter sementes, como é o caso de $E$. biflorum, é admissível retirar indivíduos das populações naturais, desde que indivíduos geneticamente idênticos permaneçam na população. Em termos práticos, basta retirar uma roseta de cada touceira, deixando as demais rosetas no campo. Uma boa coleção de germoplasma de E. biflorum, portanto, pode ser formada através da coleta de uma roseta de cada touceira da população, desde que os ferimentos causados sejam mínimos. Plantas não perfilhadas não devem ser retiradas do habitat em hipótese alguma.

Nas espécies E. biflorum e E. pedicellatum, as amostragens (de sementes ou clones) devem ser realizadas em todos os agrupamentos da população, já que a AMOVA evidenciou que as diferenças genéticas moleculares entre estes agrupamentos guardam uma considerável porcentagem da variabilidade genética total destas espécies. É preferível coletar vários indivíduos por agrupamento do que poucos indivíduos em muitos agrupamentos. Uma vez que as populações são bastante reduzidas, amostrar em todos os agrupamentos não exige muito esforço. As amostras coletadas em diferentes agrupamentos devem ser mantidas separadas, ou ao menos identificadas, para que se possa reproduzir ex situ o padrão de distribuição da variabilidade genética molecular observado na natureza. Encontrar outras populações destas espécies na natureza seria de grande valia, aumentando muito o total de variabilidade genética disponível para conservação.

Na espécie E. subsecundum a amostragem deve abranger o maior número de populações. De acordo com a AMOVA, as diferenças genéticas moleculares entre as populações são responsáveis por uma considerável porcentagem do total da variabilidade da espécie. Dentro de cada população, deve-se coletar sementes de um grande número de indivíduos. As sementes coletadas em diferentes populações devem ser mantidas separadas. Os agrupamentos, tais como foram considerados nesta pesquisa, podem ser ignorados no momento da coleta, uma vez que suas diferenças genéticas moleculares representam muito pouco do total de variabilidade da espécie. 
Como há algumas populações de E. subsecundum protegidas por Unidades de Conservação, deve-se dar prioridade para populações não protegidas, procurando abranger toda a distribuição geográfica da espécie.

\subsubsection{Conservação in situ}

O simples bom senso sugere a proteção in situ das únicas populações naturais de E. biflorum e E. pedicellatum, independentemente de estudos genéticos. Pode ser que, por razões desconhecidas, aqueles sejam os únicos ambientes em que elas consigam sobreviver. Os estudos genéticos, entretanto, serviram para planejar a conservação ex situ destas espécies, além da conservação in situ e ex situ de E. subsecundum. Apesar de E. subsecundum possuir populações dentro do Parque Nacional da Serra do Cipó, seria interessante proteger mais populações, uma vez que há significativa variabilidade entre populações.

São necessários estudos, porém, para verificar a viabilidade da implantação de uma Unidade de Conservação na região de ocorrência destas espécies, bem como para definir qual o tipo de reserva mais adequado, qual seria seu tamanho, etc, estudos estes que estão além dos objetivos imediatos deste trabalho. Algumas considerações, porém, podem ser feitas.

O grau de endemismo de uma região é um importante critério para a seleção de áreas prioritárias para conservação (Gentry, 1986). A Cadeia do Espinhaço abriga um mosaico de tipos de vegetação, sendo dominada principalmente pelos Campos Rupestres, uma vegetação herbáceo-arbustiva que ocorre em áreas montanhosas acima de 900 metros. Os Campos Rupestres são reconhecidos por sua grande riqueza de espécies e endemismo (Giulietti et al., 2000; Menezes \& Giulietti 2000; Giulietti et al. 1987). Estima-se que $30 \%$ das espécies dos Campos Rupestres são endêmicas desta formação vegetacional (Giulietti et al. 1997).

A Cadeia do Espinhaço abriga mais de 4.000 espécies de plantas (Giulliet et al., 1997). Apenas na Serra do Cipó, ocorrem aproximadamente 1.590 espécies, representando 103 famílias de dicotiledôneas, 24 de monocotiledôneas, 1 de 
gimnospermas, 10 de pteridófitas e 11 de briófitas. Dentro da família Velloziaceae, por exemplo, 173 espécies ocorrem em Minas Gerais, representando 70\% do total de espécies da família. Entre as 538 espécies ameaçadas de extinção do Estado de Minas Gerais, 358 (66,5\%) habitam os Campos Rupestres (Costa et al., 1998), evidenciando a necessidade de conservação desta região.

Além do alto grau de endemismo de plantas e vertebrados, a Cadeia do Espinhaço possui relevância antropológica e potencial hídrico, sendo indicada como área de importância biológica especial (Costa et al., 1998). De acordo com os autores, dentre as regiões de pouca pressão antrópica em Minas Gerais, a Cadeia do Espinhaço é a de maior extensão. O solo e o relevo dificultam a agricultura e a ocupação humana, favorecendo a implantação de Unidades de Conservação na região.

Conforme Giulliet et al. 1997, a Cadeia do Espinhaço possui como Unidades de Conservação dois Parques Nacionais (da Chapada Diamantina e da Serra do Cipó), três Áreas de Proteção Ambiental (Gruta dos Brejões, Cavernas do Peruaçu e Cachoeira Andorinhas), dois Parques Ecológicos (do Rio Doce e Itacolomi) e uma Estação Ecológica (do Tripuí). Segundo os autores, considerando o alto endemismo da flora e fauna, as áreas protegidas representam apenas pequena parte daquilo que deveria estar protegido. Alguns exemplos de centros de extrema diversidade que estão desprotegidos, de acordo com os autores, são o Pico das Almas e a Serra do Barbado (pontos mais elevados da Cadeia do Espinhaço), o Planalto de Diamantina e a serra do Grão-Mogol. Estas áreas, conforme os autores, devem ser incluídas num plano coordenado de conservação da biodiversidade da região, após maior conhecimento da distribuição das espécies e da dinâmica dos ecossistemas.

A implantação de uma Unidade de Conservação engloba princípios ecológicos, econômicos e político-institucionais (Morsello, 2000). Com relação aos aspectos político-institucionais, um dos mais importantes na geração de conflitos é a presença de habitantes no local.

As Reservas Particulares do Patrimônio Natural (RPPN) constituem uma categoria de Unidades de Conservação recente, decorrente da limitação da possibilidade de instituição de áreas protegidas pelo poder público e da possibilidade de obtenção de 
lucros com atividades como o turismo, de acordo com Morsello, 2000. Além disso, como incentivo à criação de RPPNs, há isenção do Imposto Territorial Rural (ITR), favorecendo a criação de áreas protegidas em locais sem interesse para atividade produtiva. Com relação aos aspectos político-institucionais, nas RPPNs os problemas são mais simples, uma vez que há poucos opositores à criação destas áreas e normalmente não há habitantes no local.

Apesar Costa et al., 1998, sugerirem a implantação de grandes Unidades de Conservação na Cadeia do Espinhaço para a conservação do bioma como um todo, a implantação de pequenas reservas deve ser considerada. A implantação de RPPNs para proteger pequenas regiões da Cadeia do Espinhaço parece ser bastante adequada, uma vez que, devido ao relevo irregular e ao solo pedregoso, estas terras não possuem vocação agrícola, sendo a conservação uma alternativa vantajosa para os proprietários das terras.

Além diso, por não serem contínuos, e sim entrecortados por vales e rios, os Campos Rupestres possuem uma distribuição tal que favorece a diversificação e especiação (Harley, 1988). Desta forma, os Campos Rupestres são um mosaico de comunidades, sob controle local da topografia, microclima e condições do solo (Giullietti \& Pirani, 1988). Como cada serra abriga uma comunidade particular, a proteção de qualquer serra é valiosa, independentemente das demais. No caso dos Campos Rupestres, pequenas reservas podem proteger muitas espécies simultaneamente. Um bom exemplo pode ser dado justamente por E. biflorum e E. pedicellatum. As duas espécies ocorrem próximas uma da outra, distantes em torno de $3 \mathrm{~km}$. Entre estas duas populações, ocorre também uma população de E. magalhaesii, uma espécie vulnerável que também não ocorre em nenhuma Unidade de Conservação. Ou seja, não seria necessário implantar uma reserva muito grande para garantir a conservação de três espécies que ainda estão sem proteção. 


\section{CONCLUSÕES}

Os principais resultados obtidos foram os seguintes:

1- Encontroutse apenas um clone na população de E. biflorum; nas demais espécies não foi encontrado nenhum clone;

2- Nas três espécies, as diferenças entre indivíduos, mesmo entre indivíduos do mesmo agrupamento, são responsáveis pela maior parte da variabilidade genética molecular total;

3- As espécies restritas (E biflorum e E. pedicellatum) apresentam forte estruturação em nível de agrupamentos de indivíduos; as divergências genéticas entre estes agrupamentos guardam porcentagem considerável do total da variância genética observada para estas espécies;

4- A estruturação em agrupamentos é mais forte em E. biflorum, apesar de nesta espécie a distância entre os agrupamentos ser muito pequena;

5- Em E. subsecundum, a estruturação em agrupamentos é responsável por parcela ínfima da variabilidade genética molecular total da espécie;

6- Em E. subsecundum as divergências genéticas entre populações são responsáveis por parcela considerável do total da variabilidade genética molecular total da espécie;

7- E. subsecundum, espécie de distribuição mais ampla, apresentou a maior diversidade genética molecular total, seguida de E. biflorum. Os resultados não necessariamente são devidos à distribuição ampla de E. subsecundum, podem ser devido ao erro amostral. 
Com base nos resultados, pode-se concluir que:

1- As populações não são compostas por um ou poucos clones, como esperado antes da pesquisa;

2- As espécies restritas possuem mecanismos de manutenção da variabilidade genética; tais mecanismos são provavelmente os mesmos que aqueles propostos para outras espécies de hábito clonal;

3- Cada espécie apresenta um padrão de distribuição da variabilidade genética molecular diferente das demais, embora para todas elas a maior proporção da diversidade encontra-se entre indivíduos;

4- A interação entre fatores evolutivos e ecológicos diversos e mal compreendidos é responsável pelos padrões de distribuição da variabilidade genética molecular e pela estruturação das populações;

5- É necessário maior conhecimento dos fatores que afetam o fluxo gênico nestas espécies;

6- As três espécies provavelmente possuem sistema reprodutivo preferencialmente alógamo;

7- Foram definidas estratégias de amostragem para o estabelecimento de bancos de germoplasma ex situ para cada uma das espécies, com base nos resultados obtidos. A retirada de um único indivíduo do habitat implica em perda significativa de diversidade genética na natureza, e portanto, deve ser evitada. É admissível retirar indivíduos das populações naturais, desde que indivíduos geneticamente idênticos permaneçam na população. Nas espécies E. biflorum e E. pedicellatum, as amostragens devem ser realizadas em todos os agrupamentos da população. Na espécie E. subsecundum a amostragem deve abranger o maior número de populações. Os agrupamentos, tais como foram considerados nesta pesquisa, podem ser ignorados no momento da coleta.

8- Para a conservação in situ, deve-se procurar urgentemente meios legais de proteção às espécies E. biflorum e E. pedicellatum, principalmente. 


\section{REFERÊNCIAS BIBLIOGRÁFICAS}

AAGAARD, J.E.; KRUTOVSII, K.V.; STRAUSS, S.H. RAPDs and allozymes exhibit similar levels of diversity and differentiation among populations and races of Douglasfir. Heredity, v.81, p.69-78, 1998

AYRES, D.R.; RYAN, F.J. Genetic diversity and structure of the narrow endemic Wyethia reticulata and its congener W. bolanderi (Asteraceae) using RAPD and allozyme techniques. American Journal of Botany, v.86, p.344-353, 1999.

BAUERT, M.R.; KALIN, M.; BALTISBERGER, M. et al. No genetic variation detected within isolated relict populations of Saxifraga cernua in the Alps using RAPD markers. Molecular Ecology, v. 7, p.1519-1527, 1998

BEKESSY, S.A.; ALLNUTT, T.R.; PREMOLI, A.C. et al. Genetic variation in the vulnerable and endemic Monkey Puzzle tree, detected using RAPDs. Heredity, v.88, p.243-249, 2002.

BOUZAT, J.L. The population genetic structure of the Greater Rhea (Rhea americana) in an agricultural landscape. Biological Conservation, v.99, p.277-284, 2001.

BREMER, K.; CHASE, M.W.; STEVENS, P.F. Angiosperm Phylogeny Group - An ordinal classification for the families of flowering plants. Annals of the Missouri Botanical Garden, v.85, p.531-553, 1998.

BROWN, S.A. Genetic variation within and between some rare and common taxa of Cape Proteaceae and the implications for their conservation. Grahanstown, 1999. 169p. Tese (Doutorado) - Department of Botany, Faculty of Science, Rhodes University.

BUCCI, G.; VENDRAMIN, G.G.; LELLI, L. et al. Assessing the genetic divergence of Pinus leucodermis Ant. endangered populations: use of molecular markers for conservation purposes. Theoretical and Applied Genetics, v.95, p.1138-1146, 1997. 
BUSO, G.S.C.; RANGEL, P.H.; FERREIRA, M.E. Analysis of genetic variability of South American wild rice populations (Oryza glumaepatula) with isozymes and RAPD markers. Molecular Ecology, v.7, p.107-117, 1998.

CAETANO-ANOLLÉS, G.; BASSAM, G.J.; GRESSHOF, P.M. High resolution DNA amplification firgerprinting using very short arbitrary oligonucleotide primers. Biotechnology, v.9, p.553-556, 1991.

CHALMERS, K.J.; WAUGER, R.; SPRENT,J.I. Detection of genetic variation between and within populations of Gliricidia sepium and G. maculata using RAPD markers. Heredity, v.69, p.465-472, 1992.

CHASE, M.W.; SOLTIS, D.E.; SOLTIS, P.S. et al. Higher-level systematics of the monocotyledons: an assessment of current knowledge and a new classification. In: WILSON, K.L.; MORRISON, D.A. (Eds) Monocots: systematics and evolution. Melbourne: Csiro, 2000. p.3-16.

CHUNG, M.G.; CHUNG, J.M.; EPPERSON, B.K. Spatial genetic structure of allozyme polymorphisms within populations of Rhus trichocarpa (Anacardiaceae). Silvae Genetica, v.48, p.223-227, 1999.

COATES, D.J.; ATKINS,KA. Priority setting and the conservation of Western Australia's diverse and highly endemic flora. Biological Conservation, v.97, p.251263, 2001.

COCKERHAM, C.C. Analysis of gene frequencies. Genetics, v.74, p.679-700, 1973

COELHO, A.S.G. Dboot: avaliação dos erros associados a estimativas de distâncias/ similaridades genéticas através do procedimento de bootstrap com número variável de marcadores (software). Goiânia:Universidade Federal de Goiás, Instituto de Ciências Biológicas, Laboratório de Genética Vegetal, 2000.

COELHO, A.S.G. Bood-P: avaliação de dendrogramas baseados em estimativas de distâncias/ similaridades genéticas através do procedimento de bootstrap (software). Goiânia:Universidade Federal de Goiás, Instituto de Ciências Biológicas, Laboratório de Genética Vegetal, 2003.

COKERHAN, C.C. Variance of gene frequencies. Evolution, v.23, p.72-84, 1969.

COOK, R.E. Clonal plant populations. American Scientist, v.71, p.244-253, 1983 
COSTA, C.M.R.; HERMANN, G.; MARTINS, C.S. et al. Biodiversidade em Minas

Gerais: um Atlas para sua conservação. Belo Horizonte: Fundação Biodiversitas, 1998. $94 \mathrm{p}$.

CRONQUIST, A. An integrated system of classification of flowering plants. New York: Columbia University Press, 1981. 1261p.

CROW, J.F.; KIMURA, M. An introduction to population genetics theory. New York: Harper \& Row Publishers, 1970. 591p.

ESSELMAN, E.J.; JIANQIANG, L.; CRAWFORD, D.J. et al. Clonal diversity in the rare Calamagrostis porteri spp insperata (Poaceae): comparative results for allozymes and randon amplified polymorphic DNA (RAPD) and intersimple sequence repeat (ISSR) markers. Molecular Ecology, v.8, p.443-451, 1999.

EXCOFFIER, L.; SMOUSE P.E.; QUATTRO, J.M. Analysis of molecular variance infered from metric distances among DNA haplotypes - application to human mitochondrial - DNA restriction data Genetics, v.131, p.479-491, 1992.

FERREIRA, M.E.; GRATTAPAGLIA, D. Introdução ao uso de marcadores moleculares em análise genética. 3.ed. Brasília: Embrapa, 1998. 220p.

FISCHER, M.; HUSI, R.; PRATI, D. et al. RAPD variation among and within small and large populations of the rare clonal plant Ranunculus reptans (Ranunculaceae). American Journal of Botany, v.87, p.1128-1137, 2000.

FISHER, R.A. The genetical theory of natural selection. Oxford: Clarendon Press 1930. $272 \mathrm{p}$.

FLEISHMAN, E.; LAUNER, A.E; SWITKY, K.R. et al. Rules and exceptions in conservation genetics: genetic assessment of the endangered plant Cordylanthus palmatus and its implications for management planning. Biological Conservation, v.98, p.45-53, 2001.

FORZZA, R.C. Pitcairnioideae (Bromeliaceae) na Serra do Cipó, Minas Gerais, Brasil. São Paulo, 1997. 150p. Dissertação (Mestrado) - Instituto de Biociências, Universidade de São Paulo.

FORZZA, R.C. Echolirium: um gênero ameaçado. Bromélia, v.5, p.15-18, 1998 
FORZZA, R.C. Filogenia da tribo Puyeae Wittm. e Revisão taxonônica do gênero Encholirium Mart. Ex Schullt. \& Schult. F. (Pitcairnioideae - Bromeliaceae). São Paulo, 2001. 208p. Tese (Doutorado) - Instituto de Biociências, Universidade de São Paulo.

FORZZA， R.C; CHRISTIANINI,A.V.; WANDERLEY, M.G.L. Encholirium

(Pitcairnioideae - Bromeliaceae): conhecimento atual e sugestões para conservação.

Vidalia, v.1, p.7-20, 2003.

FRANKEL, O.H.; BROWN, A.H.D.; BURDON, J.J., The conservation of plant biodiversity. Cambridge: Cambridge University Press, 1995. 299p.

FUTUYMA, D. Biologia evolutiva. Ribeirão Preto: Sociedade Brasileira de Genética/ CNPq, 1997. 646p.

GAUER, L.; CAVALLI-MOLINA, S. Genetic variation in natural populations of mate (Ilex paraguariensis A. St. Hil., Aquifoliaceae) using RAPD markers. Heredity, v.84, p.647-656, 2000.

GE, S.; OLIVEIRA, G.C.X.; SCHAAL, B.A. RAPD variation whitin and between natural populations of the wild rice Oryza rufipogon from China and Brazil. Heredity, v.82, p.638-644, 1999.

GENTRY, A.H. Endemism in tropical versus temperate plant communities. In: SOULÉ, M.(Ed.) Conservation biology - the science of scarcity and diversity. Sunderland: Sinauer Associates, 1986. p.153-181.

GILlIES, A.C.M.; NAVARRO, C.; LOWE, A.J., et al. Genetic diversity in Mesoamerican populations of mahogany (Swietenia macrophylla), assessed using RAPDs. Heredity, v.83, p.722-732, 1999.

GIULIETTI, A.M.; HARLEY, R.M.; QUEIROZ, L.P. et al.. Caracterização e endemismo nos campos rupestres da Cadeia do Espinhaço. In CAVALCANTI, T.B.; WALTER, B. M. (Eds.), Tópicos atuais em Botânica. Brasília: Sociedade Brasileira de Botânica/EMBRAPA, 2000. p.311-318.

GIUlIETTI, A.M.; MENEZES, N.L.; PIRANI, J. R. Flora da Serra do Cipó: Caracterização e lista de espécies. Boletim de Botânica da Universidade de São Paulo, v.9, p.1-152, 1987. 
GIULIETTI, A.M.; PIRANI, J. R. Patterns of geographic distribution of some plant species from the Espinhaço Range, Minas Gerais and Bahia, Brazil. In: VANZOLINI, P.E. \& HEYER, W.R. (Eds). Procedings of a workshop on neotropical distribution patterns. Rio de Janeiro: Academia Brasileira de Ciências, 1988. p.39-69.

GIULIETTI, A.M.; PIRANI, J.R.; HARLEY, R.M. Espinhaço range region. In: DAVIS, S.D; HEYWOOD, V.H.; HERRERA-MACBRYDE, O. et al. (Eds) Centres of plant diversity: a guide and strategy for their conservation -The Americas. Cambridge: WWF/IUCN, 1997. p.397-404.

GODT, M.J.W.; HAMRICK, J.L.; BRATTON, S. Genetic diversity in a threatened wetland species, Helonias bullata ( Liliaceae). Conservation Biology, v.9, p.596604, 1995.

GUERRANT Jr., E.O. Genetic and demographic considerations in the sampling and reintroduction of rare plants. In: FIEDLER, P.L.; JAIN, S.K. (Eds) Conservation biology: the theory and pratice of nature conservation, preservation and management. Londres: Chapman \& Hall, 1992. 507p.

HAMRICK, J.L. Plant population genetics and evolution American Journal of Botany, v.69, p.1685-1693, 1982.

HAMRICK, J.L.; GODT, J.W. Allozyme diversity in plant species. In:BROWN, A.H.D.; CLEGG, M.T.; KAHLER, A.L. (Eds) Plant population genetics, breeding, and genetic resources. Sunderland: Sinauer Associates, 1989. p43-63.

HARLEY, R.M. Evolution and distribution of Eriope (Labiatae), and its relatives, in Brazil. In: VANZOLINI, P.E.; HEYER, W.R. (Eds). Procedings of a workshop on neotropical distribution patterns. Rio de Janeiro: Academia Brasileira de Ciências, 1988. p.71-120

HARTL, D.L.; CLARK, A.G. Principles of population genetics. Sunderland: Sinauer Associates, 1997, 542p.

HEDRICK, P.W. Perspective: highly variable loci and their interpretation in evolution and conservation. Evolution, v.53, p.313-318, 1999. 
HOLSINGER, K.E.; GOTTLIEB, L.D. Conservation of rare and endangered plants: principles and prospects. In: FALK, D.A.; HOLSINGER, K.E. (Eds.) Genetics and Conservation of Rare Plants. Oxford: Oxford University Press, 1991. p.195-223.

HUFF, D.R.; PEAKALL, R.;SMOUSE, P.E. RAPD variation within and among natural populations of outcrossing buffalograss [Buchloe dactyloides (Nutt.) Engelm.] Theoretical and Applied Genetics, v. 86, p. 927-934, 1993.

JAGGI, C.; WIRTH, T.; BAUR, B. Genetic variability in subpopulations of the asp viper (Vipera aspis) in the Swiss Jura Mountains: implications for a conservation strategy. Biological Conservation, v.94, p.69-77, 2000.

JAMES, E.A.; ASHBURNER, G.R. Intraspecific variation in Astelia australiana (Liliaceae) and implications for the conservation of this australian species. Biological Conservation, v.82, p.253-261, 1997.

JIMÉNEZ, J.F.; SANCHES-GÓMEZ, P.; GÜEMES, J. Genetic variability in a narrow endemic snapdragon (Antirrhinum subbaeticum, Scrophulariaceae) using RAPD markers. Heredity, v.89, p.387-393, 2002.

JONES, B.; GLIDDON, C.; GOOD, J.E.G. The conservation of variation in geographically peripheral populations: Lloydia serotina (Liliaceae) in Britain. Biological Conservation, v.101, p.147-156, 2001.

KALA, C.P. Status and conservation of rare and endangered medicinal plants in the Indian trans-Himalaya. Biological Conservation, v.93, p.371-379, 2000.

KARRON, J.D.; LINHART, Y.B., CHAULK, C.A. et al. Genetic structure of populations of geographically restricted and widespread species of Astragalus (Fabaceae). American Journal of Botany, v.75, p.1114-1119, 1988.

KELLER, B.E.M. Genetic variation among and within populations of Phragmites australis in the Charles River watershed. Aquatic botany, v.66, p.195-208, 2000.

KOPPITZ, H. Analisys of genetic diversity among selected populations of Phragmites australis world-wide. Aquatic Botany, v.64, p.209-221, 1999.

KREHER, S.A.; FORÉ, S.A.; COLLINS, B.S. Genetic variation within and among patches of the clonal species Vaccinium stamineum L.. Molecular Ecology, v.9, p.1247-1252, 2000. 
LACERDA, D.R.; ACEDO, M.D.P.; LEMOS-FILHO, J.P. et al. Genetic diversity and structure of natural populations of Plathymenia reticulata (Mimosoideae), a tropical tree from Brazilian Cerrado. Molecular Ecology, v.10, p.1143-1152, 2001.

LEME, E.M.C; MARIGO, L.C. Bromélias na natureza. Rio de Janeiro: Marigo Comunicação Visual, 1993. 183p.

LI, C.C Population genetics. Pacific Groove: Boxwood, 1976. 631p.

LOVELESS,M.D.; HAMRICK, J.L. Ecological determinants of genetic structure in plant populations Annual Review of Ecology and Systematics, v.15, p.65-95, 1984.

LOVETT DOUST, L. Population dynamics and local specialization in a clonal perennial (Ranunculus repens) I. The dynamics of ramets in contrasting habitats. Journal of Ecology, v.69, p.743-755, 1981

LUTHER, H.E. An alphabetical list of bromeliad binomials. Sarasota: The Bromeliad Society International, 2000 143p.

LYNCH, M.; MILLIGAN, B.G. Analysis of population genetic structure with RAPD markers. Molecular Ecology, v.3, p.91-99, 1994.

MAKI, M.; HORIE, S. Random amplified polymorphic DNA (RAPD) markers reveal less genetic variation in the endangered plant Cerastium fischerianum var. molle than in the widespread conspecific C. fischerianum var. fischerianum (Caryophyllaceae). Molecular Ecology, v.8, p.145-150, 1999.

MAMURIS, Z.; SFOUGARIS, A.I.; STAMATIS, C. Genetic structure of Greek brown hare (Lepus europaeus) populations as revealed by mtDBNA RFLP-PCR analysis: implications for conserving genetic diversity. Biological Conservation, v.101, p.187-196, 2001.

MARTIN, J.P.; BERMEJO, J.E.H. Genetic variation in the endemic and endangered Rosmarinus tomentosus Huber-Morath \& Maire (Labiatae) using RAPD markers. Heredity, v.85, p.434-443, 2000.

MARTINS, P.S. Preservação e genética evolutiva In: ENCONTRO SOBRE RECURSOS GENÉTICOS, Jaboticabal, 1988. Anais. Jaboticabal: Faculdade de Ciências Agrárias e Veterinárias, 1988. p.62-66. 
MARTINS, P.S. Estrutura populacional, fluxo gênico e conservação "in situ”. Instituto de Pesquisas e Estudos Florestais, v.35, p.71-78, 1987.

MATOCQ, M.D.; VILLABLANCA, F.X. Low genetic diversity in endangered species: recent or historic pattern? Biological Conservation, v.98, p.61-68, 2001.

MEDINA, E. Eco-fisiologia y evolucion de las Bromeliaceae. Boletin de la Academia Nacional de Ciencias, v.59, p.71-100, 1990.

MENEZES, N.L.; GIULIETTI, A.M. Campos Rupestres. In: MENDONÇA, M.P.; LINS, L.V. (Eds.). Lista Vermelha das Espécies Ameaçadas de Extinção da Flora de Minas Gerais. Belo Horizonte:Fundação Biodiversitas/Fundação Zoo-Botânica, 2000. p.76-83.

MORSELLO, C. Unidades de Conservação públicas e privadas: seleção e manejo no Brasil e pantanal mato-grossense. In: JACOBI, P.R. (Ed.) Ciência ambiental: os desafíos da interdisciplinaridade. São Paulo: Annablume-Fapesp, 2000. p.333-358

NEI, M. F-statistics and analysis of gene diversity in subdivided population. Annals of Human Genetics, v.41, p.225-233, 1977.

PALACIOS, C.; GONZALES-CANDELAS, F. Analyis of population genetic structure and variability using RAPD markers in the endemic and endangered Limonium dufourii (Plumbaginaceae). Molecular Ecology, v.6, p.1107-1121, 1997.

PERECIN, M.B., Diversidade genética em populações naturais de espécies de espinheira-santa, Myotenus aquilifolia Mart. E M. ilicifolia Mart ex Reiss. 134p Piracicaba, 2000. Tese (Doutorado) - Escola Superior de Agricultura "Luiz de Queiroz”, Universidade de São Paulo.

PERSSON, H.A.; GUSTAVSSON, B.A. The extent of clonality and genetic diversity in lingonberry (Vaccinium vitis- idaea L.) revealed by RAPDs and leaf-shape analysis. Molecular Ecology, v.10, p.1385-1397, 2001.

PITHER, R.; SHORE, J.S.; KELLMAN, M. Genetic diversity of the tropical tree Terminalia amazonia (Combretaceae) in naturally fragmented populations. Heredity, v.91, p.307-313, 2003. 
RAN, Y.; MURRAY, B.G.; HAMMETT, K.R.W. Evaluating genetic relationships between and within Clivia species using RAPDs. Scientia Horticulturae, v.90, p.167-179, 2001.

REIS, A.M.M. Distribuição da variabilidade genética em aroeira (Myracrodruon urundeuva, Anacardiaceae) por marcadores RAPD e polimorfismo de sequência de cpDNA. Piracicaba, 1999. 60p. Dissertação (mestrado) - Escola Superior de Agricultura "Luiz de Queiroz", Universidade de São Paulo.

ROLF, F.J. NTSYS -Pc: numerical taxonomy and multivariate analysis system. New York: Exerter Publisher, 1989. 210p.

ROSSETTO, M.; JEZIERSKI, G.; HOPPER, D. et al. Conservation genetics and clonality in two critically endangered eucalypts from the highly endemic southwestern Australia flora. Biological Conservation, v.88, p.321-331, 1999.

SAZIMA, I.; VOGEL, S.; SAZIMA, M. Bat pollination of Encholirium glaziovii, a terrestrial bromeliad. Plant Systematics and Evolution, v.168, p.167-179, 1989.

SCHNEIDER, S.; ROESSLI, D.; EXCOFFIER, L. Arlequin ver. 2000: a software for population data analysis (software). Geneva: University of Geneva, Genetic and Biometry Laboratory, 2000. http://anthropologie.unige.ch/arlequin/ (21 Nov. 2002)

SHANNON, C.E. A mathematical theory of communication, Bell Sys tem Technical Journal, v.27, p. 379-423, 1948

SHARMA, I.K. Understanding clonal diversity patterns through allozyme polymorphism in an endangered and geographically restricted Australian shrub, Zieria baeuerlenii, and its implications for conservation. Biochemical Systematics and Ecology, v.29, p.681-695, 2001.

SHARMA, I.K.; CLEMENTS, M.A.; JONES, D.L. Observations of high genetic variability in the endangered Australian terrestrial orchid Pterostylis gibbosa R. Br. (Orchidaceae) Biochemical Systematics and Ecology, v.28, p.651-663, 2000.

SILVEIRA, S.R; RUAS, P.M.; RUAS, C.F. et al. Assessment of genetic variability within and among coffee progênies and cultivars using RAPD markers Genetics and Molecular Biology, v.26, p.329-336, 2003. 
SLATKIN, M. The average number of sites separating DNA sequences drawn from a subdivided population. Theoretical Population Biology, v.32, p.42-49, 1987.

SMITH, J.A.C. Epiphytic Bromeliads In: ULRICH LUTTGE (Ed.). Vascular Plants as Epiphytes- Evolution and Ecophysiology. Berlin: Springer-Verlag, 1989. p.108-138.

SMITH, L.B.; DOWNS, R.J. Flora Neotropica Monograph n.14 (PITCAIRNIOIDEAE) (BROMELIACEAE). New York: Hafner Press, 1974. $658 \mathrm{p}$.

SPELLERBERG, I.F; FEDOR, P.J. A tribute to Claude Shannon (1916-2001) and a plea for more rigorous use of species richness, species diversity and the "ShannonWiener" index Global Ecology and Biogeography, v.12, p.177-179, 2003.

SUN, M; WONG, K.C. Genetic structure of three orchid species with contrasting breeding systems using RAPD and allozyme markers. American Journal of Botany, v.88, p.2180-2188, 2001.

SYDES, A.M.; PEAKALL, R. Extensive clonality in the endangered shrub Haloragodendrom lucasii (Haloragaceae) revealed by allozymes and RAPDs. Molecular Ecology, v.7, p.87-93, 1998.

TANSLEY, S.A.; BROWN, C.R. RAPD variation in the rare and endangered Leucadendron elimense (Proteaceae): implications for their conservation. Biological Conservation, v.95, p.39-48, 2000.

VANDEWOESTIJNE, S; BAGUETTE, M. The genetic structure of endangered populations in the Cranberry Fritillary, Boloria aquilonaris (Lepidoptera, Nymphalidae) : RAPDs vs allozymes. Heredity, v.89, p.439-445, 2002.

VARADARAJAN, G.S.; GILMARTIN, A.J. Phylogenetic relationships of groups of genera within the subfamily Pitcairnioideae (Bromeliaceae). Systematic Botany, v.13, p.283-293, 1988.

VENCOVSKY, R. Análise de variância de freqüências alélicas. Genetics and Molecular Biology, v.15, p.53-60, 1992. 
WADT, L.H.O., Estrutura genética de populações naturais de pimenta longa (Piper hispidinervum C.DC.) visando seu uso e conservação. Piracicaba, 2001. 95p. Tese (Doutorado) - Escola Superior de Agricultura "Luiz de Queiroz”, Universidade de São Paulo.

WALLER, D.M.; O’MALLEY, D.M.; GAWLER, S.C. Genetic variation in the extreme endemic Pedicularis furbishiae (Scrophulariaceae). Conservation Biology, v.1, p.335-340, 1987.

WANDERLEY, M.G.L.; MARTINELLI, G. Bromeliaceae. In: GIULIETTI, A.M.; MENEZES, N.L.; PIRANI, J.R. et al. Flora da Serra do Cipó, Minas Gerais: caracterização e lista de espécies. São Paulo: Boletim de Botânica da Universidade de São Paulo, 1987. v.9, p.1-152.

WEIR, B.S. Genetics data analysis II: methods for discrete population genetic data. Suderland:Sinauer Associates, 1996. 455p.

WRIGHT, S. The interpretation of population structure by F-statistic with special regard to systems of mating. Evolution, v.19, p.395-420, 1965.

WRIGHT, S. Evolution in Mendelian populations. Genetics, v.16, p.97-159, 1931

ZUCCHI, M.I., Análise da estrutura genética de Eugenia dysenterica DC utilizando marcadores RAPD e SSR. Piracicaba, 2002. 130p. Tese (Doutorado) - Escola Superior de Agricultura "Luiz de Queiroz”, Universidade de São Paulo. 